INTER NATIONAL MONETARY FUND
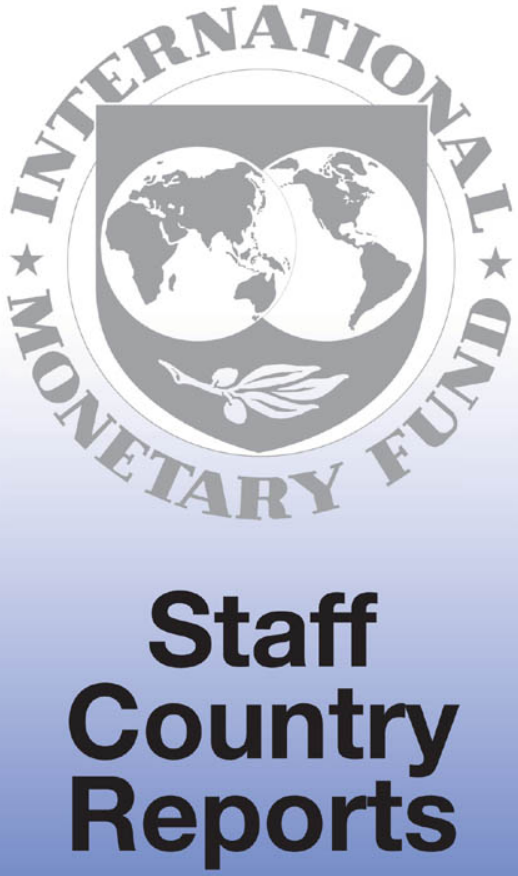


\section{Pakistan: 2002 Article IV Consultation, Third Review Under the Poverty Reduction and Growth Facility Arrangement, and Request for Waivers of Performance Criteria-Staff Report; Staff Statement; Public Information Notice on the Executive Board Discussion; and Statement by the Executive Director for Pakistan}

Under Article IV of the IMF's Articles of Agreement, the IMF holds bilateral discussions with members, usually every year. In the context of a combined discussion of the 2002 Article IV consultation with Pakistan, third review under the Poverty Reduction and Growth Facility arrangement, and request for waivers of performance criteria, the following documents have been teleased and are included in this package:

- the staff report for the 2002 Article IV consultation, third review under the Poverty Reduction and Growth Facility arrangement, and request for waivers of performance criteria, prepared by a staff team of the IMF, following discussions that ended on August 21, 2002, with the officials of Pakistan on economic developments and policies. Based on information available at the time of these discussions, the staff report was completed on October 18, 2002. The views expressed in the staff report are those of the staff team and do not necessarily reflect the views of the Executive Board of the IMF.

- a staff statement of October 31, 2002 updating information on recent economic developments.

- a Public Information Notice (PIN) and a News Brief summarizing the views of the Executive Board as expressed during its November 1, 2002 discussion of the staff report that concluded the Article IV consultation, the third review under the Poverty Reduction and Growth Facility arrangement and request for waivers of performance criteria, respectively.

- a statement by the Executive Director for Pakistan.

The document(s) listed below have been or will be separately released.

Letter of Intent*

Menorandum of Economic and Financial Policies*

Technical Memorandum of Understanding*

Selected Issues and Statistical Appendix Paper

*May also be included in Staff Report.

The policy of publication of staff reports and other documents allows for the deletion of market-sensitive information.

To assist the IMF in evaluating the publication policy, reader comments are invited and may be sent by e-mail to Publicationpolicy(a)imforg.

Copies of this report are available to the public from International Monetary Fund - Publication Services

$70019^{\text {th }}$ Street, N.W. - Washington, D.C. 20431

Telephone: (202) 623-7430 • Telefax: (202) 623-7201

E-mail: publications@imf.org Internet: http://www.imf.org

Price: $\$ 15.00$ a copy

International Monetary Fund Washington, D.C. 
INTERNATIONAL MONETARY FUND

PAKISTAN

\title{
Staff Report for the 2002 Article IV Consultation, Third Review Under the Poverty Reduction and Growth Facility Arrangement, and Request for Waivers of Performance Criteria
}

\author{
Prepared by the Middle Eastern and the \\ Policy Development and Review Departments
}

(In consultation with other departments)

Approved by Pierre Dhonte and Michael T. Hadjimichael

October 18, 2002

- Discussions for the 2002 Article IV consultation and the third review under the Poverty Reduction Growth Facility (PRGF) arrangement were held jointly in Islanabad from August 9-21, 2002. The staff team consisted of Mr. Enders (Head), Messrs. Le Dem and Joly (all MED); Mr. Breuer (ICM); Mr. Schimmelpfennig (FAD); Mr. Sobolev (PDR); and Ms. Dakanay (Staff Assistant, MED). Mr. Chabrier (Special Advisor to the Managing Director) joined the mission for two days. The mission was assisted by Mr. Ghesquiere (Senior Resident Representative). Staff from the World Bank's resident mission participated it some of the discussions.

- Messrs. Chabrier, Enders, and Ghesquiere met with President Musharraf in Islamabad on August 20. The mission held meetings with the Ministers for Finance, Commerce, Petroleum, and Privatization; the Governor of the State Bank of Pakistan (SBP); the Secretary Gencral Finance and Secretary Finance; and other senior officials dealing with economic and financial matters. The mission also met with the heads of major public enterprises, as well as with representatives of the banking sector. Mr. Ahtned (OED)

participated in the discussions.

- At the conclusion of the last Article IV consultation on Pakistan on November 29, 2000, Executive Directors observed that the key policy challenges in the period ahead would be to maintain macroeconomic discipline and improve the compelitiveness of the economy and public debt dynamics. They considered fiscal consolidation-especially an improved revenue effort-essential for consolidating macroeconomic stability, while progress with structural reform would be necessary for attracting private investment, achieving high growth, and alleviating poverty. Directors identified enbancing governance, broadening of the tax base, strengthening of tax administration, and improving the financial position of public enterprises and banks, as particularly important structural reform areas. In completing the second review under the PRGF arrangement on July 3,2002, Directors commended the authorities for consolidating gains in macroeconomic stability and making progress with the implementation of their reform agenda in a difficult economic and political environment. Directors emphasized the need to avoid further shortfalls in Central Board of Revenue (CBR) revenue, and to shift public resources towards human development. In case a further increase in regional tension triggered a decline in confidence, they recommended undertaking appropriate conective fiscal measures if needed to achieve the budgetary targets, and allowing the exchange rate to adjust, while limiting the use of reserves. Directors welcomed the $2002 / 03$ budget, including the underlying tax reform package, as well as recent and planned measures to improve tax administration and the monitoring of public enterprises. They urged the authorities to pursue the reform of the two power utilities.

- The principal authors of this report are Klaus Enders and Hervé Joly, with inputs by Peter Breuer, Jean Le Dem, Alina Milasiute, Axel Schimmelpfennig, and Yuri Sobolev. 
List of Acronyms 4

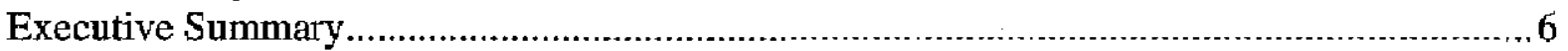

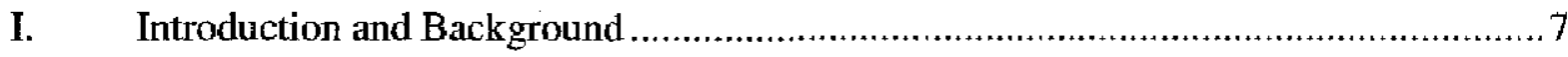

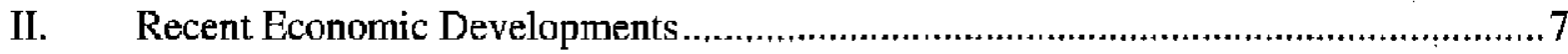



A. Achievements over the Last Two Years and Main Challenges ....................11

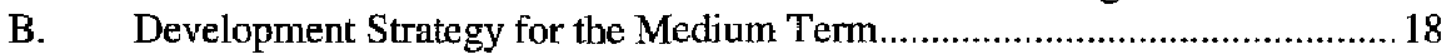

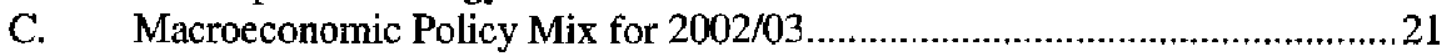



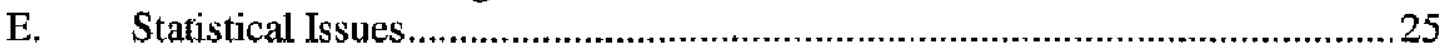

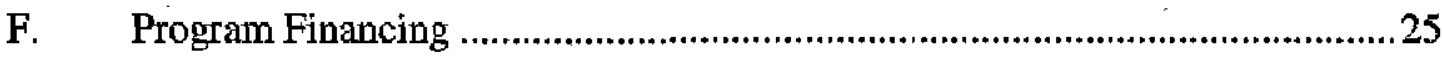

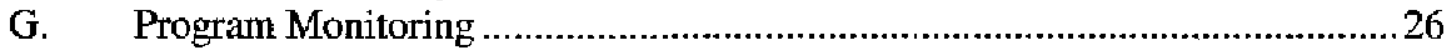

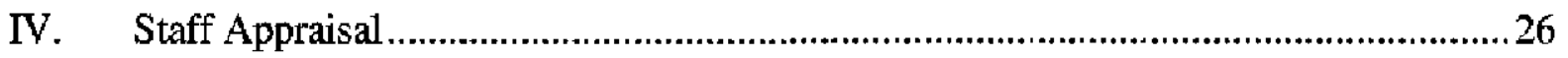

Text Boxes

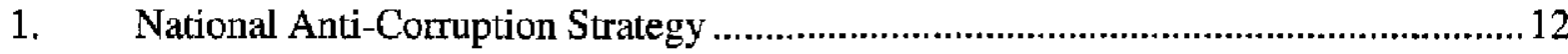

2. Draft Fiscal Responsibility and Debt Limitation Ordinance ............................ 14

3. Banks' Financial Soundness Indicators: Recent Results,

Impacts of Ongoing Reforms and Challenges Ahead ..................................15



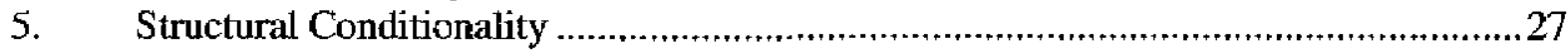

\section{Figures}

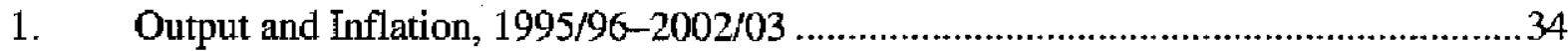

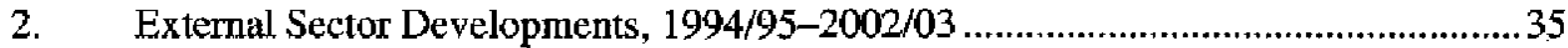

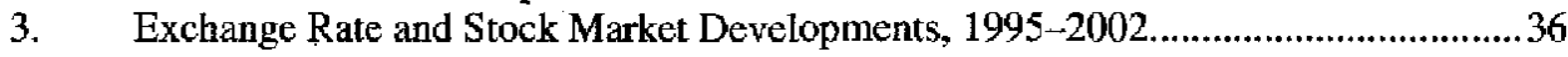

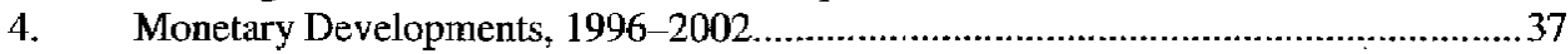

5. Fiscal Developments, 1993/94-2002/03 .......................................................38

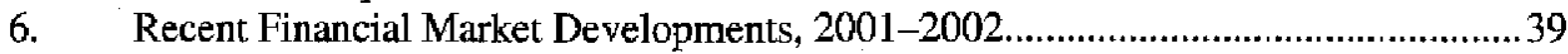

\section{Tables}

1. Medium-Term Macroeconomic Framework, 2000/01-2006/07 ...........................40

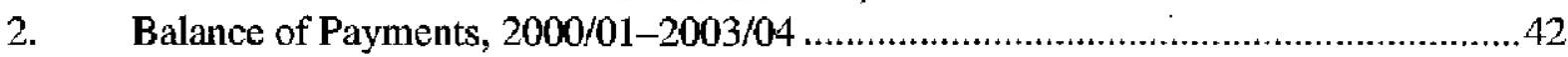

3. Consolidated Government Budget (In billions of Pakistani rupees),

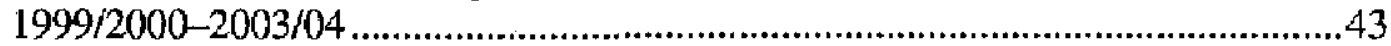

4. Consolidated Government Budget (In percent of GDP), 1999/2000-2003/04 ........44

5. Monetary Survey, 1999/2000-2002/03 ….....................................................45

6. Accounts of the State Bank of Pakistan, 1999/2000-2002/03 ................................46

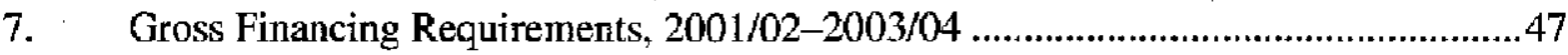

8. Summary of Public External Debt and Debt Service, $1998 / 99-2003 / 04 \ldots \ldots \ldots \ldots \ldots \ldots . . .48$ 
9. Indicators of External Vulnerability, 1998/99-2001/02 ….......................................49

10. Indicators of Fund Credit, 2000/01-2007/08 ...................................................50

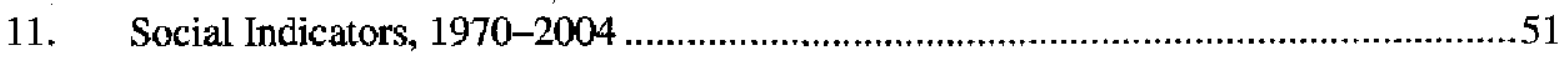

\section{Appendices}



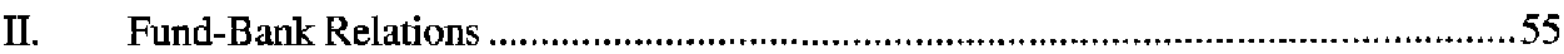

III. Statistical Issues.........................................................................................60

Annexes

I. $\quad$ Trade and Foreign Exchange System Reforms …….............................................66

II. Public and External Debt Sustainability ............................................................67

Attachments

I. Letter of Intent, Memorandum of Economic and Financial Policies, and Amendments to the Technical Memorandum of Understanding...........................71

II. Update of Fiscal ROSC …............................................................................... 89 


\section{List of Acronyms}

\begin{tabular}{|c|c|}
\hline $\mathrm{ABP}$ & Allied Bank of Pakistan \\
\hline ADBP & Agricultural Development Bank of Pakistan \\
\hline AFMF & Accountable Fiscal Management Framework \\
\hline AGPR & Accountant General Pakistan Revenue \\
\hline AML & Anti-Money Laundering \\
\hline AsDB & Asian Development Bank \\
\hline CBR & Central Board of Revenue \\
\hline CGA & Comptroller General of Accounts \\
\hline CIRC & Corporate and Industrial Restructuring Corporation \\
\hline DFID & Department for International Development (United Kingdorn) \\
\hline EOI & Expression of Interest \\
\hline FBS & Federal Bureau of Statistics \\
\hline FCD & Foreign Currency Deposit \\
\hline FEC & Foreign Exchange Company \\
\hline FIP & Financial Improvement Plan \\
\hline FSAP & Financial Sector Assessment Program \\
\hline FMC & Fiscal Monitoring Committee \\
\hline GDDS & General Data Dissemination Standard \\
\hline GST & General Sales Tax \\
\hline HBL & Habib Bank Ltd. \\
\hline I-PRSP & Interim Poverty Reduction Strategy Paper \\
\hline IFIs & International Financial Institutions \\
\hline KESC & Karachi Electric Supply Corporation \\
\hline MEFP & Memorandum of Economic and Financial Policies \\
\hline MFI & Microfinance Institution \\
\hline NAB & National Accountability Bureau \\
\hline NACS & National Anti-Corruption Strategy \\
\hline NAM & New Accounting Model \\
\hline NDA & Net Domestic Assets \\
\hline $\mathrm{NDFC}$ & National Development Finance Corporation \\
\hline NEPRA & National Electric Power Regulatory Authority \\
\hline NFA & Net Foreign Assets \\
\hline $\mathrm{NSC}$ & National Security Council \\
\hline NPL. & Nonperforming Loan \\
\hline NSS & National Saving Schemes \\
\hline NWFP & North West Frontier Province \\
\hline OGDC & Oil and Gas Development Company \\
\hline PIA & Pakistan International Airlines \\
\hline PIFRA & Pakistan Improvement of Financial Reporting and Accounting \\
\hline PIHS & Pakistan Integrated Household Survey \\
\hline PR & Pakistan Railways \\
\hline PRGF & Poverty Reduction and Growth Facility \\
\hline PRSP & Poverty Reduction Strategy Paper \\
\hline PSE & Public Sector Enterprise \\
\hline
\end{tabular}




$\begin{array}{ll}\text { PSM } & \text { Pakistan Steel Mills } \\ \text { PSO } & \text { Pakistan State Oil } \\ \text { PTCL } & \text { Pakistan Telecommunications Company Limited } \\ \text { ROSC } & \text { Report on the Observance of Standards and Codes } \\ \text { SAC } & \text { Structural Adjustment Credit } \\ \text { SBP } & \text { State Bank of Pakistan } \\ \text { SDDS } & \text { Special Data Dissemination Standard } \\ \text { SME } & \text { Small and Medium Enterprises } \\ \text { SOQ } & \text { Statement of Qualification } \\ \text { TFP } & \text { Total Factor Productivity } \\ \text { TMU } & \text { Technical Memorandum of Understanding } \\ \text { UBL } & \text { United Bank Limited } \\ \text { WAPDA } & \text { Water and Power Development Authority }\end{array}$




\section{Executive Summary}

Developments since 2000 indicate continued progress on stabilization and structural reform. Growth and inflation performance have been quite respectable given the difficult environment. Strong private capital inflows and remittances helped to build a high level of official reserves and contributed to a stable exchange rate vis à vis the U.S. dollar. A steady rise in exports and imports and improving tax collection since April 2002 point to a recovery of the real economy from the post-September 11 slump, despite continued regional tensions. Social sector spending rose sharply in the last quarter of FY 2001/02, indicating that the startup problems of the elected local governments are being overcome. On the structural front, strong progress was made in the areas of tax administration, fiscal transparency, and trade and exchange reform. Privatization is proceeding as planned in the oil/gas sector; delays in other sectors, especially for telecoms and the power utilities, reflect in part the difficult situation in world equity markets. Financial improvement plans for several public entities are being implemented to contain their drain on the budget

All but three of the quantitative and structural performance criteria for the period endJune through end-September 2002 were met. The authorities request a waiver for the nonobservance of the performance criteria on CBR revenue at end-June 2002, on bringing the Karachi Electric Supply Corporation (KESC) to the point of sale by end-July 2002, and on not introducing new tax exemptions. They also request a modification of the performance criterion on CBR revenue for end-December 2002.

The discussions highlighted a few lessons drawn from the experience of recent years. One was the importance of reducing the burden of public debt through continued fiscal adjustment, with projections based on cautious assumptions regarding the impact of reform, notably on growth. Debt dynamics remain somewhat vulnerable to shocks, in particular to a slackening of the reform effort-a frequently occurring "shock" in Pakistan's history. Another was the recognition that a deepening of structural/institutional reform, and higher and more efficient spending on human development, was needed to ensure more substantive progress in raising growth and reducing poverty.

The authorities plan to maintain the current mix of macroeconomic policies to keep the economy on a path of declining public debt, and to stimulate growth and job creation. Monetary policy will target low inflation within a flexible exchange rate system. Fiscal policy will aim to reduce the public debt overhang while enhancing the effectiveness of expenditure in stimulating growth and reducing poverty. A financial improvement plan for KESC has been formulated in case the planned privatization proves impossible before year end. A broad range of governance reforms aims to ensure a better monitoring of budgetary spending and outcomes, enhance the accountability of public enterprises, and increase efficiency and reduce corruption in tax administration, the judiciary, and the police.

The main risk to the outlook is a further aggravation of regional tensions that could derail the expected recovery of trade and investment, jeopardize the fiscal targets and/or the planned shift of resources to human development, and weaken the ability of the government to implement politically difficult reforms. 


\section{INTRODUCTION AND BACKGROUND}

1. The last Article IV consultation with Pakistan was concluded on November 29, 2000 (Country Report No. 01/24). Pakistan has accepted the obligations of Article VIII and maintains an exchange system free of restrictions on payments and transfers for current international transactions. On December 6, 2001, the Executive Board approved Pakistan's request for a three-year arrangement under the PRGF with access of 100 percent of quota (SDR 1,033.7 million) and endorsed the country's Interim Poverty Reduction Strategy Paper (I-PRSP). The Executive Boatd completed the second review of the program on July 3, 2002, thus enabling Pakistan to draw SDR 86 million. 'As of August 31, 2002, total Fund credit and loans outstanding to Pakistan amounted to SDR 1,481 milion (143.3 percent of quota). Upon completion of the third review, a disbursement of SDR 86 million would become available.

2. In the attached letter dated October 16, 2002, and the attached Memorandum of Economic and Financial Policies (MEFP) (Attachment I), the government of Pakistan requests completion of the third review under the PRGF arrangement, a technical modification of the performance criterion on CBR revenue for end-December 2002, and waivers for the nonobservance of performance criteria on (a) the Central Board of Revenue (CBR) revenue through June 2002; (b) bringing KESC to the point of sale by end-July 2002; and (c) not granting any new tax exemptions.

\section{RECENT ECONOMIC DEVELOPMENTS}

\section{The economic outlook remains clouded by regional and domestic security} concerns. Tensions with India have diminished somewhat since late June, but large military forces are still deployed along the border and skirmishes remain frequent across the Line of Control. Isolated domestic terrorist acts have occurred, especially in Karachi, Pakistan's largest city and commercial center, and in the area around Islamabad.

4. Elections for the national and provincial parliaments were held on October 10, 2002, with participation of a large number of political parties. In August 2002, the government promulgated amendments to the constitution, including extending General Musharraf's presidency for five years and instituting a National Security Council (NSC) as a constitutional body to be consulted on strategic issues. The NSC will be chaired by the President and will include a majority of civilians, including the leader of the parliamentary opposition, as well as representatives from the armed forces. The government considered the amendments as needed to protect the reforms of the last three years.

5. Despite the security situation and the proximity of elections, the government has broadly held the course on reforms and recent macroeconomic developments have been encouraging. Continued regional tension and the associated risks may partly explain the

\footnotetext{
'Country Report No. 02/141. Pakistan's relations with the Fund are described in Appendix I. Relations with the World Bank Group are described in Appendix $\amalg$.
} 
depressed levels of private investment, but have had otherwise little visible impact on the economy up to now. As detailed below, macroeconomic performance has improved further in recent months: growth has perked up and inflation remains below 4 percent, official reserves have increased much faster than anticipated, and the budget deficit for FY 2001/02 (ending June 2002) was lower than expected, despite a significant pickup in social sector spending in the last quarter (Tables 1-6 and Figures 1-6). In July and August, exports, imports, and CBR revenue continued the recovery observed since April. Structural reforms have been pursued broadly in line with the agenda set under Pakistan's poverty reduction strategy.

6. Real GDP growth and inflation were broadly in line with program projections in 2001/02. As detailed in the MEFP (paras. 2-3), preliminary official estimates indicate that real GDP (at factor costs) grew by 3.6 percent, slightly higher than programmed. Average inflation in 2001/02 was 2.7 percent, one of the lowest in Pakistan's history. However, inflation picked up in the first half of 2002 , with the 12-month CPI increase almost doubling from December 2001 to 4 percent in July 2002, before slowing to 3.7 percent in August 2002.

7. The balance of payments position improved faster than expected. The current account, excluding grants, recorded a small surplus in 2001/02 on account of a better-thanexpected trade balance and continued strong worker remittances. Combined with substantial exceptional financing in the form of debt rescheduling and program financing from international financial institutions (IFIs), this allowed the State Bank of Pakistan (SBP) to build up foreign exchange reserves in the course of the year much faster than expected, to US $\$ 4.3$ billion at end-June 2002, equivalent to four months of next year's imports of goods and nonfactor services. Since late 2001 , the Pakistani rupee has remained virtually stable against the U.S. dollar, with large foreign exchange purchases by the SBP, exclusively in the interbank market after June 2002, preventing a further appreciation.

8. The budget deficit target for $2001 / 02$ (as set during the first review) was met, despite a shortfall in CBR revenue. The overall deficit (excluding grants) decreased to 5.1 percent of GDP, from 5.3 percent in $2000 / 01,{ }^{2}$ and compared to a program target of 5.7 percent. Lower than expected spending, in particular interest payments, more than offset shortfalls in CBR revenue collection from the (revised) annual program target by about 0.3 percent of GDP. Most of the shortfall was incurred in January-March 2002, mainly due to lower than expected imports. ${ }^{3}$ Revenue collection improved substantially in the quarter to June 2002 (in fact by more than assumed in the projection underlying the FY 2002/03 targets) as imports and economic activity strengthened, but also because GST and customs

\footnotetext{
${ }^{2}$ This definition of the budget balance excludes outlays for KESC recapitalization (PRs 30 billion), and the settlement (by a bond issue) of excess taxes paid by banks on unrealized profits through 2000 (PRs 22 billion). The "augmented" budget deficit, including grants and the above one-off outlays, which matters for debt dynamics, amounted to 4.2 percent of GDP.

${ }^{3}$ See Country Report No. 02/141, Box 1.
} 
refunds were somewhat slowed. Nontax revenue was higher than expected due to strong dividend receipts from public sector enterprises (PSEs), broadly offsetting shortfalls in the petroleum surcharge and provincial tax collection. According to (as yet unreconciled) accounting data, social- and poverty-related I-PRSP expenditure picked up significantly during the fourth quarter, so that the indicative annual target (of 3.7 percent of GDP) was almost met.

9. As detailed in the June 2002 MEFP, the 2002/03 budget adopted in late June 2002 aims to contain the deficit (excluding grants) at 4.4 percent of GDP, consistent with program objectives. It includes a major tax reform package and provides an explicit commitment to the I-PRSP expenditure target for 2002/03 ( 4 percent of GDP). The deficit may be increased for higher social expenditure (up to 0.5 percent of GDP) if financed by additional grants, and for payment to KESC to settle arrears as part of the privatization strategy (up to 0.3 percent of GDP). The drive toward broadening the tax base ran into some difficulties following the extension of the sales tax to pharmaceuticals in March 2002. The tax had provoked widespread opposition and hostility, undermining the support for the program in general and the credibility of its anti-poverty focus in particular. In April 2002, the authorities attempted to diffuse such hostility by exempting life-saving drugs, consistent with program commitments. However, the large number of exemptions made administration of the tax nearly impossible, and public opposition did not subside. Thus, the authorities decided in August 2002 to eliminate the tax and take measures in the form of increased petroleum product taxation to offset the estimated annual revenue loss of PRs 2 billion. Since this offsetting measure is made outside CBR revenue, the quarterly CBR targets from December 2002 onward were reduced accordingly.

10. Broad money increased strongly in 2001/02, despite efforts to sterilize foreign exchange inflows. The SBP contained reserve money growth through an aggressive sterilization of its foreign exchange purchases during the second half of the fiscal year, which led to a sharp contraction of its net domestic assets (NDA). However, the banking system's NDA recorded a slight increase partly on account of a moderate rise in credit to the private sector. As a consequence, the very large accumulation of net foreign assets (NFA) by the banking system led to an almost 16 percent annual increase in broad money through end-June 2002 . Interest rates have remained relatively stable since early 2002 , with the yield on sixmonth treasury bills hovering about 6.5 percent. The main stock market index rose by 57 percent in the year to August 31, 2002.

11. The structural reform agenda is broadly on track (MEFP, para. 2). Significant tax policy and administration measures were taken in the past months, and a customs administration reform plan has been prepared (with technical assistance requested from the Fund for finalizing the plan). Steps toward better monitoring of large public enterprises include the adoption of performance plans and monitoring frameworks for the Water and Power Development Authority (WAPDA), Pakistan International Airlines (PIA), Pakistan Steel Mills (PSM), and Pakistan Railways (PR). Somewhat later than expected, the National Electric Power Regulatory Authority (NEPRA), the power sector's regulator, granted WAPDA a structural tariff increase of 9.2 percent, lower than initially expected under 
WAPDA's financial improvement plan (FIP), especially for the low-consumption "lifeline" slab, to protect poor consumers. The privatization program is experiencing delays in some of the more difficult cases, largely reflecting turmoil in global equity markets and security concerns (MEFP, para. 6 and 17). Nonetheless, a final bidding for United Bank Limited (UBL) took place in early September and a majority stake in UBL was sold to a foreign group. The sale of minority interests in various companies was also concluded.

12. In the run-up to the elections and confronted with surging international oil prices, the government has delayed or weakened the adjustment of energy prices. In September 2002, the authorities decided to postpone the increase in consumer gas prices scheduled for September under the medium-term gas pricing framework agreed to with the World Bank; a weaker-than-expected structural tariff increase was granted to KESC (NEPRA granted a 6.5 percent increase, whereas KESC had filed for 16 percent); and some petroleum surcharges were lowered mid-September and early October to cushion the impact of surging world oil prices on consumers. As indicated in the MEFP, the authorities committed to raising the petroleum surcharges by end-October 2002 to the levels consistent with program revenue projections. A first step was taken on October 15, 2002 with increases in the surcharges across all products; the authorities plan the remaining adjustment with the next fortnightly petroleum price adjustment on October 31, 2002.

13. Reforms in the financial sector made significant progress in the past three months. The Supreme Court's ruling in late June 2002 (MEFP, para. 20) has cleared the way for implementation of the authorities' evolutionary approach, developing Islamic banking alongside conventional banking and leaving market participants the choice between these institutions. Recent amendments to the SBP Act have increased the SBP's independence, in line with the Fund's Safeguards Assessment recommendations. A draft Anti-money Laundering Law is expected to be promulgated in the near future. It includes provisions to criminalize money laundering, set up a financial intelligence unit, and allow freezing and forfeiture of assets as well as international cooperation. With the support of the Asian Development Bank (AsDB), the authorities have started reforming the Agricultural Development Bank of Pakistan (ADBP), notably through preparing the separation of half of ADBP"s staff through a "golden handshake" and partial restructuring of its balance sheet (MEFP, para, 19). In July 2002, the SBP eliminated administrative restrictions on the setting of interest rates on foreign currency deposits (FCDs), and set a deadline of two years for moneychangers to transform into regulated foreign exchange companies (FECs). To better link the interbank foreign exchange market to the free ("kerb") market, banks have been allowed to buy foreign exchange from moneychangers at freely negotiated rates since January 2002.

\section{REPORT ON THE DISCUSSIONS}

14. The discussions were held against the background of the near-completion of the three-year rule of the military government and the imminent returi of parliamentary government. The authorities reminded the staff of the economic situation they had inherited in late 1999: after several failed attempts at addressing deteriorating public debt dynamics in 
the $1990 \mathrm{~s},{ }^{4}$ increasing external vulnerability eventually had resulted in a balance of payments crisis in 1998. The government, in office since October 1999, therefore put at the heart of its initial economic strategy a program of macroeconomic adjustment. Following the successful completion of a stabilization program supported by an IMF Stand-By Arrangement, a more comprehensive medium-term reform strategy was set forth in Pakistan's I-PRSP that aimed to (a) improve the investment climate in the country; (b) reduce the economy's vulnerability to external or internal shocks; and (c) put the economy on a sustainable growth path, and ensure that growth translates into palpable improvements in living standards for the population at large, and the poor in particular. The policy package to achieve these objectives centered on fiscal adjustment to bring debt to sustainable levels while raising social and poverty-related expenditure, and a wide range of governance reforms to stimulate private sector growth and improve social service delivery.

15. The 2002 Article IV consultation discussions focused on the effectiveness of this economic policy strategy to date. The authorities and staff also reassessed growth prospects, in particular in light of the relatively disappointing growth performance over the last decade. In the context of the third review under the PRGF arrangement, the authorities and staff more specifically (a) reviewed economic developments and policy implementation in the quarter to June 2002; (b) assessed the prospects for achieving the program targets for end-September 2002; and (c) formulated proposals for the end-March 2003 quantitative targets, as well as additional struciural measures on KESC and WAPDA reform. Discussion of other structural targets for 2003 was postponed to the next review, to be held with the new government, as critical input will be needed from the planned review of progress in tax and customs administration reform (with FAD technical assistance); the translation of the draft anti-corruption strategy into a specific action plan (Box 1); and the formulation of an alternative strategy regarding KESC should privatization in the near future prove impossible. This approach will also allow the new government emerging from the election to take full ownership of the future structural reform agenda.

\section{A. Achievements over the Last Two Years and Main Challenges Ahead}

\section{The authorities' policies, combined with strong international financial and} economic support, have been successful in restoring and consolidating macroeconomic stability over the past two years, despite several adverse shocks. A slowdown in the world economy, high oil prices, protracted drought, trade disruption in the wake of September 11, and regional and domestic security problems have increased uncertainty for businesses and hampered growth. In this unfavorable context, the overall economic performance has been quite encouraging: real GDP growth averaged about 3.5 percent over the past two years (and thus was modestly positive in per capita terms), and inflation remained subdued. The external accounts recorded a dramatic turnaround, allowing the SBP to build up reserves to levels unprecedented in Pakistan's history.

\footnotetext{
${ }^{4}$ See also the recent IEO case study on Pakistan (Evaluation of the Prolonged Use of Fund Resources-Report on the Case Studies, Volume II).
} 


\section{Box 1. National Anti-Corruption Strategy}

To improve upon existing mechanisms to fight corruption the new government established the National Accountability Bureau (NAB) in 1999. The anthorizing ordinance updated the Prevention of Cornption Act of 1947 by providing the govemment with extensive powers to investigate alleged corrupt behavior both by holders of public office and by members of the public, including for the first time legislators and willful defaulters. It permitted the presumption of guilt based on the accumulation of wealth and shifted the burden of proof to the accused.

Despite these efforts, corruption in Pakistan remains "pervasive and deeply entrenched", as acknowledged by a recent report by the NAB. While the NAB has had some successes in tackling "grand" corruption cases, little progress has been made in fighting low-level corruption. ${ }^{2 /}$ The annual Coruption Perceptions Index published by Transparency International (TI) -an intermational nongovernmental organization devoted towards combating comuption-ranked Pakistan $77^{\text {th }}$ out of 102 countries surveyed in 2002 . $^{3 /}$ This ranking indicates an improvement of Pakistan's relative position, as the proportion of countries ranked below Pakistan doubled from 12 percent of the total sample in 1999 to 25 percent in 2002, although it is in part due to an increase in the number of countries inchuded in the survey. Pakistan's score on the index improved marginally from 2.2 to 2.6 during the same period, broadly in line with other South Asian countries. In September 2002 , TI is expected to publish a survey of 3000 respondents' experience of corruption in Pakistan, providing some indication of the extent of corruption in government departments, among građes/posts within those departments, and the average bribe paid.

In an effort to accelerate the pace of reform, the NAB is formulating a National Anti-Corruption Strategy (NACS), ${ }^{4 t}$ based on a broad review and assessment of the causes and extent of conuption. According to a preliminary repotl, the strategy focuses on prevention to complement the existing enforcement approach. The preliminary report, which is to be finalized in September 2002, calls for strengthening accountability and transparency in government and civil society by:

- Creating the political will for reform by building a broad coalition of stakeholders through participatory mechanisms.

- Ensuring a wide adoption of anti-corruption policies by assigning responsibility for thcir implementation to a broad based Steering Committee consisting of stakeholder institutions.

- Downsizing the public sector to reduce opportunities for corruption through privatization, reduction of the number and level of selected taxes, and lowering the staff-to-officers ratio.

- Strengthening public sector management through decentralization, simplification, standardization and transparency of procedures, including procurement, introduction of "whistleblower" protection, and through introducing greater accountability (e.g. passage of Freedom of Information Act).
- Enhancing human resources in the public sector by increasing remuneration, providing an adequate and secure work environment for public employees, simplifying the code of conduct, and introducing meritbasedf recruitment procedures.

- Strengthening public watchdog bodies by giving them greater autonomy (Auditor General's Department), appointing chairmen from the opposition (Public Accounts Commituee), and building capacity (Ombudsman offices).

- Promoting social change by empowering civil society through increased access to govemment, enhancing consumer rights legislation, and improving regulation of nongovemmental organizations.

- Ensuring fair and efficient legal processes by vigorously implementing the Access to Justice Program, abolishing the ability to acquire assets under another person's name ("Benami" practice), and simplifying laws and procedures.

1/ The provincial Anti-Comption Establishments and the Federal Investigation Agency continue to pursue their anti-corruption tasks in parallel.

2/ The NAB has so far recovered PRs 80 billion and held 154 inquiries against politicians, including a former prime minister, former federal ninisters, 290 inquiries against bureaucrats, 38 agajnst businessmen, and seven against officials of the armed forces.

3/ The Corruption Perceptions Index score reflects the perception of the degree of corruption as seen by business people, academics, and risk analysts, and ranges between 10 (highly clean) and 0 (highly corrupt). It is a composite index using surveys from different sources. 4/ A Pretiminary report, discussed at a National Anti-Comuption seminar in Llamabad in July 2002. 
17. Though revenue collection has not improved as much as needed, progress in fiscal consolidation has been significant. Staff stressed that revenue collection has remained a weak spot in Pakistan's public finances, with CBR having repeatedly missed tax collection targets. The overall tax effort remains insufficient to extricate Pakistan from its debt trap, while simultaneously ensuring the needed significant increase in social expenditures. The authorities emphasized that, nonetheless, the overall fiscal situation has improved. The budget deficit (including grants) decreased from 5.5 percent of GDP in 1999/2000 to 4.2 percent of GDP last fiscal year. As highlighted in the public debt sustainability exencise (Annex II), this contributed-together with the appreciation of the Pakistani rupee and the use of government deposits to retire a large amount of treasury bills - to the significant decline in the gross public debt ratio last fiscal year (to 98 percent of GDP). However, the burden of public debt (with debt service absorbing nearly one-third of government revenue) remained heavy and constrained government spending on development. The authorities pointed to their (published) debt management strategy that endorsed continued fiscal adjustment to reduce public debt, along with policies to reduce the cost of borrowing. Specifically, nonconcessional external borrowing was to be kept within tight limits and the cost of borrowing under the National Saving Scheme (NSS) brought closer to market levels. The authorities recently published for public comment a draft Fiscal Responsibility Law (Box 2) that aims to enshrine the debt strategy in the law.

\section{The authorities pointed to the steadfast implementation of their comprehensive} structural reform agenda, focusing on improved governance. Staff recognized that tangible progress has been made in broadening the tax base through elimination of a wide range of sales tax and income tax exemptions, and in preparing the basis for an efficient and accountable tax administration through a modernization of CBR's procedures, including the ongoing move to self-assessment and functional integration of tax administration across taxes. Fiscal accountability and transparency have drastically improved with faster and more comprehensive reconciliation of federal and, to a lesser extent, provincial expenditure data, and regular publication of fiscal accounts including, more recently, progress reports on I-PRSP spending (see the fiscal ROSC update in Attachment III). Trade and exchange system reforms (Annex I) have substantially reduced protection and anti-export bias, and established an exchange system that is free of restrictions on current payments and transfers. ${ }^{5}$ The reduction of the number of special regulatory orders and adoption of a streamlined Foreign Exchange Manual have substantially increased transparency and reduced scope for rentseeking in this area. In the financial sector, the restructuring and privatization of the nationalized banks is advancing well (Box 3), and important reforms of prudential regulations and steps to tackle nonperforming loans have been undertaken. The authorities recognized that several important weaknesses of the financial sector had yet to be forcefully addressed, notably reform of the NSS and of various nonbank financial institutions.

\footnotetext{
5 All exchange transactions for current payments and transfers that can take place in the free ("kerb") market can also take place in the interbank market, and therefore no multiple currency practice arises.
} 


\section{Box 2. Draft Fiscal Responsibility and Debt Limitation Ordinance ${ }^{1 /}$}

- In June 2002, the government published a draft federal fiscal responsibility and debt limitation ordinance, inviting public comment. ${ }^{2 /}$ The draft ordinance is intended to achievc an ambitious debt reduction strategy over the coming decade. First, reporting requirements would inform the National Parliament and the public on fiscal developments, fiscal policy, and progress towards the debt target. Second, quantitative fiscal rules would constrain annual federal budgets. Successful debt reduction will reduce fiscal vulnerabilities and create room for additional non-interest expenditures in the areas of social and development spending.

- The draft ordinance requires the government to report regularly on fiscal policy and developments. The reports would nest the annual budget in a three-year medium-term budget framework and explain how the budget relates to the debt target. The reports would also provide background information on vulnerabilities, contingent liabilities, and underlying assumptions. Moreover, the reports would assess fiscal outcomes and progress on debt reduction. Staff considers that the reporting requirements are sound, but will require that additional administrative capacity to be built in the areas of medium-term budgeting, costing, and asset and debt reporting. Staff recommends that the ordinance set out a timetable for capacity building and phase in reporting requirements accordingly.

- The draft ordinance contains three quantitative rules (a) public debt is to be reduced to 60 percent of GDP by 2011/L2; (b) public debt is to be reduced by at least $2 \frac{1}{2}$ percent of GDP each year; and (c) the current balance must be in surplus by 2006/07. In case social and poverty-related expenditure falls below 4 percent of GDP or in case of a national emergency or a natural disaster, fiscal policy can deviate from the rules. The draft ordinance also limits issuing new guarantees to 2 percent of GDP per fiscal year.

- Staff believes that the draft ordinance could be simplifed by setting a debt target as the overarching objective and having a fiscal rule that determines an overall balance floor or an expenditure ceiling consistent with that target. An overall balance floor would be calculated based on the difference between the debt target and the actual debt stock, taking into account the GDP growth. An expenditure ceiling would be calculated from the overall balance floor and revenue projections. Both rules would directly feed into the budget process. The expenditure ceiling would allow for automatic stabilizers on the revenue side and thus be somewhat more flexible than the overall balance floor. The current balance rule ("golden rule") would not be needed for debt reduction, but could be useful in the budget process. The escape clause for social and poverty expenditure conld be restated as an overarching objective, which would feed into the process of prioritizing expenditures. The escape clause for national emergencies or natural disasters should be more clearly specified as an ex-post adjuster.

- The draft ordinance could be extended to provincial and local governments. As devolution proceeds, a larger share of fiscal policy is carried out at the subnational level and should be subject to the same debate and scrutiny as fiscal policy at the federal level. Moreover, devolution will reduce the federal government's control over macro fiscal policy and public debt, which could potentially threaten the debt reduction strategy. A balanced budget requirement for provincial and local governments could address such concerns.

1/ For a more detailed assessment, see the forthcoming Selected Issues and Statistical Appendix paper. $2 /$ Available at www.finance.gov.pk/law/main.html. 


\section{Box 3. Banks' Financial Soundness Indicators: Recent Results, Impact of Ongoing Reforms, and Challenges Ahead (continued)}

Pakistan initiated in-depth structural reforms in the banking sector in the early 1990 s to reverșe the previous trend of bank nationalizations, state control, and directed credit. Later, confronted with increasing credit risks and governance issues, the authorities accelerated banks' modernization, including the privatization of three major commercial banks, including UBL in September 2002, an overhaul of the legal and accounting framework, a strengthening of financial supervision, and a shift to market-oriented policies. A recent SBP study suggests a yet modest impact of these teforms on the soundness of the banking sector. "As of end-December 2001:

- The capital adequacy ratio was on average equal to 11.4 percent; four connercial banks were below the prudential minimum of 8 percent. ${ }^{2}$

- Credit risks remain high but limited to statc-owned banks. The ratio of nonperforming over cotal loans stabilized to 19.6 percent, from 19.5 percent in 2000 , and 22 percent in 1999 . Stricter classification rules enforced by the SBP pushed this ratio up, largely offsetting a stepped-up drive to loan recovery, and initial transfers of bad loans from stateowned banks to the Corporate and Industrial Restructuring Corporation (CIRC).

- The lack of profitability of commcrcial banks, both in terms of return on assets and return on equity, is mainly caused by the state-owned banks' situation. In spite of high spreads between lending and deposit rates (close to 6 perecnt), private banks" profitability has declined and also remains low by international standands. The decline reflects in part the impact of the freeze of FCDs in 1998 and the related elimination of schemes that provided safe and high returns to banks.

- Conmercial banks' liquidity risk is limited. Cash teserve requirements and statutory liquidity requirements constrain banks to keep 5 percent and 15 percent of their deposits in cash and government bonds that are eligible to SBP refinancing, respectively. Banks' liquidity has also been enhanced in 2001 by a low economic growth and the lack of opportunities to lend to the private sector.

- Available data do not permit a clear assessment of banks' exposure to risks of macroeconomic shocks. The dollarizalion of bank deposits has been considerably reversed (14.5 percent in June 2002, from 19.6 percent a year earlier, and more than 40 percent in 1998) but continues to expose banks to sjgnificant foreign exchange risks, since capital mobility is relatively high in Pakistan, although several prudential regulations imposed by the central bank limit these risks. "Maturity mismatch for some banks that hold large amounts of long-tem govemment bonds and the bigh concentration of loans in the textile industry are two possible risks which warrant attention.

\section{The impact of the ongoing reforms}

The authorities are pursuing policies that should bring more decisive improvements in the banks' financial soundness in the medium term:

- The SBP is progressively increasing banks' minimum capital requirements, from PRs 500 million to PRs 750 million by January 1, 2002 and to PRs 1 billion by Jantary I, 2003. This is expected to trigger mergers between or acquisition of undercapitalized banks.

- The ongoing privatization of state-owned banks, which still account for the majority of assets of the banking sector, and the restructuring measures prior to their privatization are expected to improve banks' overall capital-adequacy, asset quality, and profitability indicators. Measures include (a) the SBP's recapitalization of UBL (PRs 8 billion); (b) the consolidation of banks' outstanding tax refund claims on CBR (PRs 22 billion) and claims on KESC (another PRs 22 billion) into Ireasury bonds; (c) CIRC's purchases at a market-based discount of state-owned banks" assets (above PRs 30 million) in arrears for at least one year (as of August 2002, some PRs 26.5 billion of such assets had been sold for a market price of PRs 5.1 billion); and (d) cost-saving measures initiated in 2001, including the closure of nonprofitable branches and government-financed golden handshake programs (about 7,000 staff since June 2001, for a total cost of PRs 7 billion). 


\section{Box 3. Banks' Financial Soundness Indicators: Recent Results, Impact of Ongoing Reforms, and Challenges Ahead (concluded)}

\section{Remaining Challenges}

The SBP has identifiexl four directions for further refongs (a) further restructuring/privatization of specialized banks and nonbank financial institutions; (b) enhanced judicial/regulatory/supervision framework; (c) intproved monetary policy and market mechanisms for interest rates; and (d) improved supply of financial instruments. While broadly agreeing with this strategy, staff insisted on the need to rely more on market forces to reshape a modern financial system. In addition, staff stressed the need to improve the SBP's monitoring of the banks' resilience to macroeconomic shocks, and raised three additional challenges. ${ }^{\text {t }}$

- The Einancial system remains too fragmented by tax distortions, including discriminatory income tax rates against. banks. Tax rates have been reduced from 58 percent to 50 percent but are still well above the standard corporate tax rate of 35 percent, which applies for other financial institutions such as leasing companies and investment banks. Banks' specific provisions against nonperforning loans should be tax deductible. Tax distortions also discourage mergers between banks, as well investment in pension funds.

- Distortions affecting deposit collection or credit allocations prevent banks' fair competition with other finance institations. Although adequate regulations for the stock exchange and for the leasing industry have been in place for some years, the development of modern long-term financial intermediation instruments is still hampered by statesponsored savings schemes, and public nonprofitable development finance institutions and insurance companies. At end-June 2002 , about 40 percent of total financial savings were still channeled to the government through the National Saving Schemes. No paper except government bonds was eligible to the refinancing of the SBP, and credit to the agricultural sector was still directed.

- The regulatory and judicial framework needs further reform. The recovery of bad loans is still excessively long and costly. The treatment of nonperforming loans is hampered by the lack of clear guidelines for writing-off bad loans. Banks should be given more opportunities to diversify their loan portfolio and reduce their vulnerability to cyclical shocks, in particular the textiles sector, through legal steps to iruprove the solvable demand for credit in housing and agriculture, as well as measures to improve corporate governance and companies" financial disclosure. The recent adoption of a regulacory framework to promote the development of sound microfinance institutions, while key for poverly reduction, could also offer new development perspectives for banks.

1f At end-December 2001, the banking sector consisted of 39 banks (8 state-owned banks, 12 domestic private banks, and 19 foreign banks).

2f These prodential ratios, which are discussed in more details in the forthcoming Selected Issues and Statistical Appendix paper, are subject to confirmation on a bank-by-bank basis, one of the tasks that an FSAP mission is expected to perform in the coming months.

3/The CIRC was established in September 2000 as an autonomous body under the Ministry of Finance to "promote the revitalization of the economy by reviving sick industrial units." Its main function is to rccover minimum one-year overdue loans of PRs 30 million and more on behalf of the state-owned banks and development finance institutions. As of end-June 2002, some 10.2 percent of the total stock of NPLs had been transferred to CIRC at market prices, for about 19.2 percent of their face value. CIRC has at most three years to pay for the transfer (less if the bank is privatized), partly in cash (through the liquidation of the collateralized assets), partly in five-year bonds (for the residual).

4/ Banks' foreign exchange position cannot exceed 10 percent of their capital; 20 percent of FCDs need to be placed with the central bank and banks are not allowed to collect FCDs more than 20 percent of their total deposits and provide for exchange-denominatci loans to enterprises, except. for short-term export credits.

5/ These and other issues were debated in depth during a large conference organized to discuss the results of the SBP study on the financial system in June 2002 in Karach. Many of the planned reforms are being formulated in the context of a second capital market reform operation supported technically and financially by the AsDB. 
Reform of social service delivery is also underway, with an ambitious devolution plan aimed at empowering local communities to take charge of basic social services. Staff felt that significant challenges still loom in the public enterprise sector, where privatization and restructuring have made only limited progress.

19. Staff concurred with the authorities' assessment that the economic strategy adopted over the past two years was broadly the right one. During the discussions, some voices within the government expressed the view, quite widespread in Pakistan's academia and media, that fiscal policy has been overly tight in recent years, thus depressing private investment and curbing economic growth. Other officials concurred with staff that there was no real alternative to the modest fiscal adjustment of the past few years to prevent public debt from spiraling out of control, and to avoid further undermining business confidence and private investment.

20. While firm quantitative evidence is not (yet) available, the authorities concurred with staff that it was unlikely that much progress has been made in recent years in reducing poverty, although without the reforms poverty might have risen quite dramatically. The lack of progress on poverty reduction mostly reflects continued low levels of private investment and growth, the impact of drought on the rural regions, and inadequate provision of basic social services as public spending on human development remains too low (0.5 percent of GDP on health and 1.8 percent on education in 2001/02, about half of the ratio in the average low income country). Staff pointed to World Bank analysis indicating that some of the main institutional causes of poverty (ownership of land and other assets, lack of a functioning judicial system, deep-rooted gender issues, etc.) have yet to be fully addressed. In finalizing the PRSP, even greater emphasis and specificity needs to be given to such issues. Another urgent task in the context of finalizing the PRSP will be a realistic costing of achieving the authorities' social targets, to ascertain more firmly the level of human development expenditure required to rapidly improve Pakistan's poor social indicators. Staff welcomed the strong increase in 2001/02 in education and health spending over the preceding year (by 17 percent and 34 percent, respectively), and the planned further increase in $2002 / 03$ (by 18 percent and 10 percent, respectively), which would put I-PRSP spending ahead of defense spending. Staff sympathized with the authorities' view that, concomitant with stepping up such expenditure, better expenditure and outcome controls have to be put in place, but expressed concern that implementation of systems to monitor (intermediate) outcomes has been too slow. Staff urged the authorities to put in place quickly practical monitoring systems so as to get at least preliminary indications on which social programs work and which do not. In this way, the authorities would have an important input for formulating the next budgets at the district and provincial levels. At least as important, timely accounting of all expenditure at the local government levels needs to be fully assured, without which I-PRSP spending cannot not be meaningfully assessed. Led by the World Bank's Social Development Unit, social impact analysis is currently underway to assess the (a) devolution and its impact on the quality of service delivery, especially to the poor, and (b) the impact of tariff reforms in the gas and power sectors. 


\section{B. Development Strategy for the Medium Term}

21. In light of these achievements and challenges, the authorities and staff reviewed the development strategy for the medium term. Discussions focused on macroeconomic policies, the structural reform agenda, sustainability and vulnerability issues, and political economy considerations regarding reform ownership and acceptance by the population.

22. The authorities believe that current macroeconomic policies remain appropriate to foster high growth, reduce vulnerability, and ensure public debt sustainability. They underscored that these policies have already brought significant macroeconomic stability gains and increased the economy's resilience to shocks. With time, and in a less disruptive economic context than last year's, these policies should help create an enabling environment for private investment and activity as the driving force for growth and poverty reduction. The authorities recognized the need to diversify the export base, especially in light of the prospective expiration of the multi-fibre agreement. They hoped to achieve this diversification through removing anti-export biases in trade policies and maintaining a competitive exchange rate, in certain cases complemented through sector-specific strategies. The authorities were encouraged by the results of the public debt sustainability exercises: debt to GDP ratios are expected to decrease steadily, assuming that current reforms will continue to be implemented and have the intended impact within a relatively short time. Shocks of magnitudes similar to those experienced in the 1990s seem unlikety to trigger unsustainable debt dynamics. Staff stressed that a combination of such shocks could still result in instability, and that the most important danger, which had so often materialized in Pakistan's history, was that the reform effort was not sustained over a sufficiently long period.

23. The authorities stressed their commitment to pursue the implementation of their structural reform agenda, centered on improving governance at all levels of government and the further liberalization of the economy. The most urgent task was reform of the public enterprise sector, as it accounts for a significant share in GDP and employment. Within this sector of about 50 enterprises, many were on track for privatization (banks, oil and gas enterprises, telecommunications, cement) and others currently required only limited budgetary support (steel and airline), within the context of ongoing restructuring operations that involved in some cases partial privatization. The bulk of direct budgetary support went to WAPDA and KESC (about 1 percent of GDP in 2001/02), and staff stressed that for the two utilities the need to implement greater efficiency and accountability was largest. The authorities shared with staff a comprehensive draft anti-corruption strategy, to be discussed by the cabinet shortly. In the context of preparing the PRSP, which is expected to be finalized by the new government, the authorities stressed their willingness to deepen participation through consultation at provincial and district levels, strengthen mechanisms to measure and monitor poverty-related data and intermediate outcome indicators, and improve the costing of reaching the social targets in the context of a medium-term budgeting framework. The authorities regretted that repeated postponement of the planned FSAP mission (for security reasons) has deprived them of important input for their financial sector reform strategy. 


\section{Staff broadly concurred with the reform agenda but cautioned the authorities} about the risk of being overly optimistic regarding expected outcomes, and highlighted the vulnerability of the outlook to various risks. In particular, staff argued that, given the modest growth performance of the late 1990s (Box 4), medium-term projections should be based on cautious growth assumptions. The baseline projections imply a pronounced structural break in economic and financial outcomes compared to the $1990 \mathrm{~s}$, in particular a significantly higher growth rate (about 5 percent on average, compared to 3.4 percent during the preceding 10 years). Such a break could be achieved through governance and other reforms resulting in an acceleration of total factor productivity (TFP) growth by about 1 percentage point, and a modest increase in investment. To the extent that reforms would accelerate human capital growth and/or labor force participation, growth could also be higher (or fewer improvements in TFP may be needed). At the same time, the impact of the reforms may not be as pronounced as expected and some of it may bear fruit later than hoped for. Another major risk is that the reform effort proves once again short-lived, as has happened so often in Pakistan's history. The authorities were, however, confident that reforms would be maintained, and saw the forthcoming election as an opportunity to anchor reforms in a broader political consensus. They concurred that continued regional tensions were an important risk. The latter could manifest itself in different ways: higher defense expenditure if the stand-off with India is prolonged or escalates; acts of domestic terrorism deterring investors; real and/or perceived security concerns affecting export orders, insurance premia and other trading costs; and loss of confidence leading to pressures on the capital account. They agreed with staff that they needed to be ready with appropriate contingency measures to deal with such risks (as discussed below).

\section{The authorities and staff discussed some political economy aspects of the} reforms. Noting that many media in Pakistan take it for granted that measures are dictated by the IMF, with little government ownership, staff stressed the need for the authorities to explain more actively the rationale for the reforms and their ownership by the government. The authorities acknowledged hostility to the reform program in some media, which they attributed partly to the absence of "tangible" early successes to demonstrate that reforms are paying off. The progress in reducing inflation and the build-up of reserves were not perceived as tangible benefits by the "common man." By contrast, the steps needed to pass on unexpectedly high oil prices had reinforced a public perception associating the adjustment program with a never-ending series of hikes for oil product prices and utility tariffs. While the business community was broadly supportive of the reforms, opposition reflected in part the stance of interest groups that stood to lose from the reforms: part of CBR staff and tax dodgers benefiting from weaknesses in the tax administration; workers and bureaucrats who stood to lose rents and power through the restructuring/privatization of public enterprises and banks; households and selected groups of consumers benefiting from current distortions in utility tariffs and weak bill collection; and certain industries benefiting from high protection. While acknowledging these constraints, staff stressed that greater focus on poverty reduction through improved social services would help to deliver tangible benefits and thereby increase public support for the reforms. 


\section{Box 4. Growth Accounting, 1960-2001 ${ }^{\text {y }}$}

From 1960 to 2001 Pakistan's real GDP growth rate trended downward, to about 3 percent in the late 1990 s compared with 6 percent in the $1960 \mathrm{~s}$. To highlight the role of factor accumulation in explaining this trend, a standard growth accounting exercise was based on a Cobb-Donglas production function with three aggregate inputs - physical capital $(K)$; labor $(L)$; and human capital $(H)$-and assuming constant returns to scale and equal factor-income shares. ${ }^{2 /} A$ denotes total factor productivity (TFP) and $\boldsymbol{Y}$ regl GDP, thus:

$Y=A K^{1 / 3} H^{1 / 3} L^{1 / 3}$

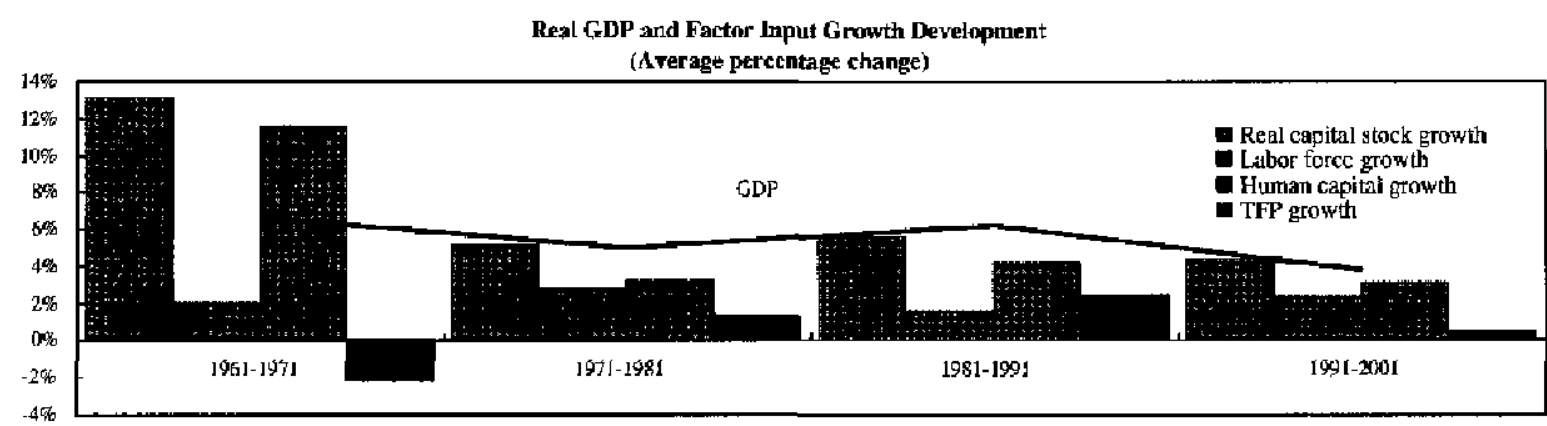

The results" indicate that awerage real GDP growth of 5.5 percent during 1961-2001 was mininly driven by factor accumulation, especially of physical and human capital. The real capital stock grew by an average of 7.2 percent annually during 1961-2001, faster than any other production factor and peaking in the 1960s with average annual growth rates of 13 percent. The average human capital stock growth of 5.8 perceut reflects solid improvements in education (especially in the $1960 \mathrm{~s}$, when average schooling years for the population increased to $1.68 \mathrm{in} 1970$, from 0.63 in 1960 ), as well as an average labor force growth of 2.3 percent per year. The decline in trend growth over the period is mostly explained by slowing human and physical capital stock growth (e.g-s average schooling years increased to only 1.74 by $1980,2.29$ by 1990 , and 2.45 by 2000 ).

TFP growth was a minot contributing factor in explaining overall growth. It grew by 0.4 percent per year on average, but experienced negative average growth rates in the 1960 s (-2.2 percent from 1961 to 1971) and again in the mid-1990s (-0.8 percent from 1994 to 1998). The causes of negative TFP growth deserve further investigation. Empirical economic growth studies suggest that low TFP growth may be explained by low foreign direct investment and trade, which would slow incorporation of technological progress in the economy, as well as a deterioration of governance. ${ }^{a /}$

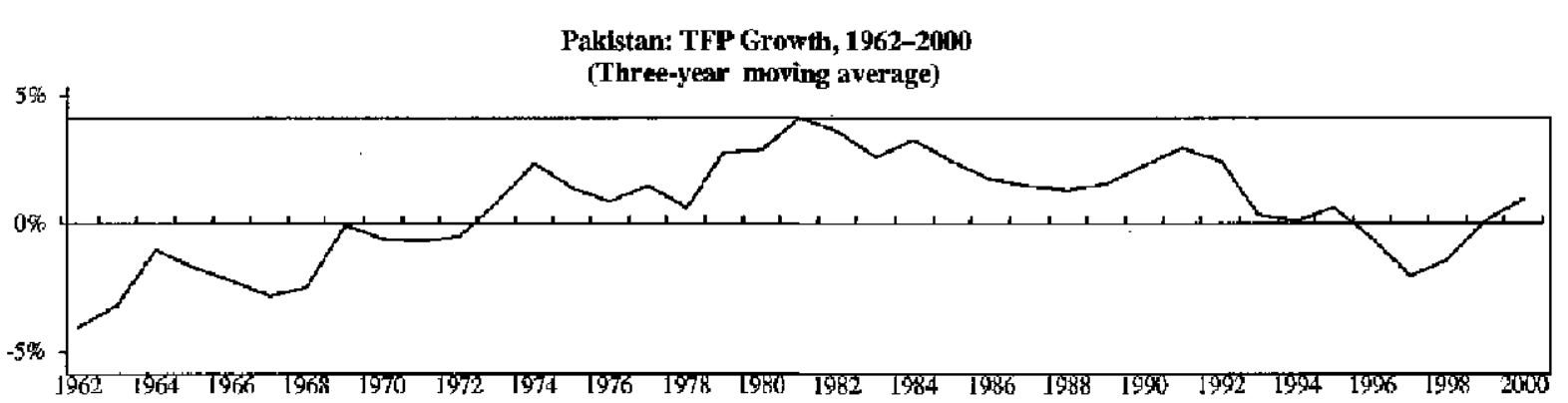

1/ For an expanded analysis, the forthooning Selected Issues and Statistical Appendix paper.

$2 /$ Human capital data, proxied by average years of schooling for the population aged over 25 years, come from Barto, Robert, and Jong-Wha Lee, 2001, "Intemational Data on Educational Anainment: Updates and Implications", Working Paper 79|1. NBER.

3/ To assess the robustness of this exercise, different factor-income shares were used with no significant effects on the overall results.

4/ An important role of governance (proxied by the International Conntry Risk Guide (ICRG) ratings) is found in Olson, M., Sama, N., \& Swamy, A.V., Govemance and Growth: A Simple Hypothesis Explaining Cross-Country Differences in Productivity Growth, Pubfic Choice, 102: 341-364. 


\section{Macroeconomic Policy Mix for $2002 / 03$}

26. Despite the persistence of significant uncertainty, the main macroeconomic objectives under the program for 2002/03 were maintained (MEFP, para. 10). Recent developments are consistent with real GDP growth of 4.5 percent and inflation of 4 percent. The current account (including official transfers) is expected to move from a surplus to balance on account of a strong increase in imports and lower remittances and official transfers, more in line with historical trends. The capital account deficit is projected to be marginally lower compared to 2001/02 due to lower public sector net short-term outflows. Net private capital flows are expected to fall from the levels recorded in 2001/02, assumed to reflect in part one-time portfolio shifts, although certain structural shifts are likely to be sustained: first, a decline in the supply of foreign exchange in the free market, reflecting some shift in transfers from the Hawala system to formal channels, possibly along with a decline in unrecorded exports to Afghanistan. Second, a fall in demand because of lower capital outflows (reflecting relatively greater confidence in Pakistan-held assets), as well as possibly a fall in smuggling from Afghanistan. Net exceptional financing would somewhat decrease from a record 2001/02 level. Gross official reserves are expected to rise by about US $\$ 1$ billion in the course of the year, to the equivalent of about five months of imports.

27. The authorities intend to maintain the current combination of a flexible exchange rate and monetary policy aimed at keeping inflation in check. They concurred with staff that, given the recent inflation pickup and uncertainty about money demand, monetary policy should be tightened to prevent the emergence of further inflationary pressures, and they revised the targets for broad money and reserve money growth stightly downwards. This would be implemented through more aggressive open market operations to sterilize the impact of foreign exchange purchases. At the same time, the authorities felt that there had been a shift toward higher money demand, part of an overall shift in favor of Pakistani assets. They concurred, however, that should inflation accelerate, further tightening would be needed, even though relatively high real interest rates, and a strong exchange rate, pointed to relatively tight monetary conditions at this time. The authorities were aware of the need to develop more forward looking monetary policy indicators and were assessing the option of moving to an inflation targeting framework.

28. The authorities consider that a flexible exchange rate has served the economy well and concurred with staff that the exchange rate does not seem to be currently misaligned, a view that appears to be shared by the private sector. Staff argued that a sustained appreciation of the real effective exchange rate should be avoided, if needed by stepping up sterilized foreign exchange purchases. Maintaining competitiveness was critical, given the need to run relatively low current account deficits to reduce the external debt burden over the next few years, and to diversify the export base. The large net private capital and remittances inflows observed since late 2001 have allowed Pakistan to achieve a step increase in international reserves that provided a more comfortable cushion against major future shocks. In case of a reversal of the capital flows, which could not be excluded if the regional/political environment were to deteriorate, allowing a market-based depreciation and financial tightening should be the first line of defense, with reserves used only sparingly to 
maintain orderly market conditions. At the same time, staff recognized that developments through August/September pointed to the possibility that higher levels of capital inflows could continue longer than expected. Staff and authorities concurred that the run-up in the stock market was not of major concern: capitalization was still very low (about 10 percent of GDP) and while there was probably an element of speculation, it also reflected a fundamental improvement in business confidence.

29. The fiscal projections for $\mathbf{2 0 0 2 / 0 3}$ have been revised, including several changes to the planned expenditure composition, but remain consistent with the original financial program. CBR revenue has been reduced by PRs 1.7 billion on account of exempting medicines from the GST, to be offset by an increase in petroleum surcharges. Nontax revenue has been revised upwards on the assumption that WAPDA would pay its full dues to the budget. While projected foreign interest payments have been lowered due to revised data and more favorable interest rate assumptions (based on preliminary bilateral debt relief negotiations), other expenditure items have been increased. In particular, additional subsidies of about PRs 20 billion were allocated for KESC, WAPDA, ADBP, and PIA as detailed in the MEFP (para. 12). These include a PRs 11 billion settlement of KESC supplier arrears for which the original program deficit ceiling was to be adjusted. ${ }^{6}$ Taken together, the overall deficit (excluding grants) is projected to reach 4.7 percent of GDP, consistent with the original program. While recognizing that continued efforts were needed to tackle some contingent tabilities and restructure PSEs, staff expressed concern that some of the new expenditure items aim to restructure public enterprises without a firm strategy and timetable for privatization (see below). Moreover, staff voiced concern that introducing new expenditure items soon after passing the budget weakened the budget process itself.

30. Staff underscored the risks to the deficit target and the need for contingency measures. In addition to the political and security risks mentioned above, staff stressed that achievement of the budget target was also conditional upon efficiency gains in the management of public enterprises, in particular the two power utilities. The authorities indicated that should unexpected events--such as higher defense outlays, failure to privatize or restructure KESC, or insufficient improvement in WAPDA's finances - threaten the deficit target, they would consider cutting nonpriority expenditure. They were confident that the I-PRSP expenditures would be more effective in supporting social service delivery than in the past, now that district governments are operational. These expenditures would be protected from any contingent cuts as mucb as possible.

\footnotetext{
${ }^{6}$ See the June 2002 Technical Memorandum of Understanding, para. 17.
} 


\section{Structural Reform Agenda}

\section{Public enterprise reform and privatization}

31. Staff welcomed the authorities' efforts to reform major public enterprises and to improve their monitoring and accountability. The authorities and staff reviewed restructuring plans for PIA, PR, PSM, and WAPDA/successor companies. Staff stressed the importance of designing a clear privatization strategy in each case. For instance, the privatization of PIA should be considered at an early stage and any kind of government support, including guarantees for planned borrowing to finance renewal of PIA's fleet, should be strictly limited now that the airline has become profitable again. In the case of PR, staff supported the plan to involve the private sector in some activities, and encouraged the authorities to seek the World Bank's views on their ambitious plan to revamp the railways. Any government support for such a plan should be formulated only in the context of next year's budget, a view that the authorities did not fully share as they feared it could delay useful reforms. Because of the uncertain prospects for privatization, the authorities have prepared a financial improvement plan for KESC, similar to WAPDA's, with quarterly public reporting to start in November 2002. Staff underlined the need to strictly implement the plan to ensure no further budgetary support during FY 2002/03 would be needed, along with close financial reporting and monitoring of WAPDA. For the latter, it was also urgent to come to closure on the long-delayed splitting-up of assets and liabilities, and on setting transfer pricing rules among the successor companies.

\section{Staff was impressed by the authorities' willingness to push ahead with the} privatization program, despite a difficult environment. Habib Bank's privatization remains on schedule: nine expressions of interest (EOIs) and four statements of qualification (SOQs) have been received from domestic and foreign investors. Various enterprises in the petroleum sector are being prepared for privatization in the near future. In particular, EOIs have been received for Oil and Gas Development Company (OGDC, the main domestic oil producer) and Pakistan State Oil (PSO, the main distribution company). The authorities are also exploring alternative scenarios, such as management contracts, for certain public enterprises whose privatization remains uncertain in the near future.

\section{Customs and tax administration}

33. The CBR reform process remains broadly on track. A reform strategy for customs administration was drafted within the CBR and sent to Fund staff for comments; it also awaits input from consultants whose arrival in Pakistan was delayed for security reasons. A pilot model office for small- and medium-sized taxpayers will be opened in Lahore by end-October 2002, in which, as in the Karachi Large Taxpayer Unit, tax administration is organized to some extent along functional lines, breaking with traditional practices. Revised customs and sales tax refund rules and procedures are to be implemented by end-September 
2002. The authorities stressed the importance of having upgraded the CBR's supervisory council to a cabinet committee chaired by the minister of finance. The committee has been able to grant the CBR leeway in its human resource policy, including remuneration, and has endorsed financial autonomy for the CBR.

\section{Fiscal responsibility law and fiscal transparency}

34. Staff expressed strong support for the draft fiscal responsibility law, which provides a good framework that should help ensure fiscal transparency and sound fiscal management. The law is expected to be promulgated in the near future, probably once a new government has been formed. Staff commended the authorities for progress made in the past two years in terms of fiscal reporting and transparency, but stressed the importance of strengthening accounting at the local government levels and accelerating reconciliation of expenditure data to make more accurate data available within reasonable lags. Staff expressed frustration that expenditure data were still not available in appropriate functional breakdown, and emphasized the importance of moving rapidly to adoption of the new accounting model at all levels of government.

\section{Trade and exchange system reform}

35. The authorities emphasized recent measures aimed at further liberalizing the trade system, such as the tariff simplification and reduction in external protection, undertaken in June 2002, the reduction in the number of statutory regulatory orders (SROs) governing tariff exemptions, the repeal of requirements for importers and exporters to register with the Export Promotion Board, and elimination of various other administrative controls. The authorities indicated that they did not plan to introduce major changes to the trade system in the near future, so as to provide a stable environment for importers and exporters. Staff commended the authorities for their efforts to further unify foreign exchange markets. However, staff pointed out that the exchange rate premium could reappear if the free market were to return to a situation of excess foreign exchange demand, because FECs are allowed to sell (but not buy) foreign exchange in the interbank market. The authorities indicated that they would take appropriate measures to prevent emergence of a spread in excess of normal operational costs.

\section{Financial sector reform}

36. The authorities' reform strategy for the financial sector (MEFP, paras. 19-20) during the past years has increased the financial soundness of the banks overall, although further improvement is needed. Privatization of the nationalized commercial banks remains the key element to improve banks' low profitability, while efforts to recover nonperforming loans (NPL) should be increased. Staff expressed reservations about the idea of keeping some specialized financial institutions in the public sector to address possible market failures. For instance, given ADBP's poor governance record and financial situation, staff would have preferred its liquidation rather than the planned restructuring which carried the risk of continued NPL accumulation. The authorities stressed that immediate liquidation 
of ADBP would have high social costs given the absence of alternative providers of credit in the rural sector. Staff encouraged the authorities to phase out the remaining directed credit scheme to agriculture as well as to scale down the financing of commodity operations (government guaranteed bank credit extended to various public commodity boards), in line with increased private sector involvement in these activities. Staff welcomed the planned further reform of the various financial instruments offered (on tap) to individual investors under the NSS, whose generous terms unduly burden the budget and hamper the development of more market-based financial instruments. The recent establishment of privately-financed microfinance institutions (MFIs) and the related regulatory framework could address the financial needs of a significant proportion of the poor in the coming years.

\section{E. Statistical Issues}

\section{The authorities plan to speed up progress in data compilation and}

dissemination, and recently completed the last three studies that are part of the project to revise and change the base year of the national accounts. Staff expressed disappointment that publication of the new accounts is now scheduled only for 2003, and urged the authorities to take the few steps needed to participate in the GDDS, and to take up the Fund's and the World Bank's offer for assistance to compile the metadata. The authorities emphasized recent improvements in data dissemination, such as the publication of: an advance release calendar for selected statistical data; quarterly balance of payments statistics; and monthly analytical accounts of the SBP. They also indicated that they would publish by endSeptember 2002 data on reserves and foreign currency liquidity at end-June 2002 in accordance with the SDDS template. Staff urged the authorities to release the data from the latest Pakistan Integrated Household Survey (PIHS) as soon as possible, to get an updated view of recent poverty developments and allow Bank staff to conduct the social impact analyses for selected reforms envisaged in the I-PRSP. The authorities expressed, however, reservations about the reliability of these data which in their view suffered from substantive methodological problems. Apart from a few deficiencies, notably regarding the classification of government outlays and the need for better reconciliation of public debt data, staff considers that data provision to the Fund for surveillance and program monitoring purposes is broadly satisfactory (Appendix III).

\section{F. Program Financing}

38. The program remains fully financed for $2002 / 03$. The authorities and staff concurred that foreign reserve targets could be exceeded should remittances and private capital inflows continue at their current pace. However, in view of considerable uncertainty to the short-term outlook, further foreign exchange accumulation to constitute a buffer stock seems warranted. Staff urged the authorities to continue their best efforts toward concluding as soon as possible the bilateral agreements implementing the recent Paris Club Agreed Minute. The government's request for an extension of the deadline for the bilateral agreements was granted by the Paris Club creditors, and the authorities confirmed their 
intention to ensure comparable treatment of all bilateral creditors in line with the Agreed Minute. It has issued aide-mémoires to this effect to official non-Paris Club creditors. With respect to private creditors, it has initiated a restructuring of a US\$100 million loan from foreign branches of one of the nationalized banks.

\section{G. Program Monitoring}

39. Proposed prior actions, quantitative and structural performance criteria and indicative targets, and structural benchmarks are specified in the MEFP (see also Box 5). Amendments to the June 2002 TMU clarify the treatment of the privatization accounts, and update the baseline assumptions for external program financing, external grants, and deposit reserve requirements. In view of the uncertainties surrounding Pakistan's economic outlook, the program will continue to be monitored through quarterly reviews. The discussions with staff for the fourth review are expected to take place by November/December 2002 .

\section{STAFF APPRAISAL}

40. The authorities have been remarkably successful in consolidating macroeconomic stability in the past two years. Despite drought, regional and domestic security problems, and high oil prices, growth has been perking up, inflation remains subdued, the extemal accounts are in near-balance, and the central bank has made good use of continued high remittances and private capital inflows to build reserves to levels unprecedented in Pakistan's history. Fiscal adjustment, helped by external support, has begun to improve public debt dynamics. An impressive structural reform agenda is being implemented, focused on improved governance across a wide range of areas, with tangible progress in tax policy and tax administration reform, energy pricing, privatization, and fiscal accountability and transparency. There is little doubt that the economy today is far less vulnerable to extemal shocks than even a year ago. This in itself is an important contribution to the fight against poverty, both because vulnerability to economic volatility has been identified as an important cause of poverty in Pakistan, and because it is a necessary condition for the resumption of higher private investment, growth, and job creation.

\section{The discussions provided an opportunity to review the successes and}

shortcomings of recent policies and reforms. Staff hopes that the lessons drawn will prove useful input for the government emerging from the October 2002 elections in finalizing the PRSP. Staff by and large concurs with the authorities' assessment that the economic strategy adopted over the past three years was broadly the right one and that there was little alternative. In particular, staff believes it is imperative to continue the modest fiscal adjustment of the past few years, as extricating Pakistan from high public debt remains key to any recovery of private investment and for financing human capital and infrastructure development in a sustainable manner. 


\section{Box 5. Structural Conditionality ${ }^{1 /}$}

\section{Coverage of structural conditionality in the PRGF program for FY 2002/03}

Most of the structural conditionality for FY $2001 / 02$ was met. Structural conditionality for FY $2002 / 03$ is detailed in Tables 2(a) and 2(b) of the MEFP. The focus remains on tax policy and tax administration reforms, public expenditure management reforms, and fiscal transparency-all considered essential to the success of the government's growth and poverty reduction strategy. Particular emphasis is also given to public enterprise monitoring, because improving the financial situation of some of them, particularly the power utilities, is critical for achieving the targets for public tinances. The privatization of a nationalized bank is a structural benchmark, as privatization is critical to create a sound and efficient financial sector that contributes to growth, and is less vulnerable to government interference. The program includes other measures to further liberalize the financial system and to strengthen central bank autonomy in line with the Safeguards Assessment recommendations. Additional conditionality will be formulated during the next reviews, and once needed input especially from a planned teview (with technical assistance) in the area of tax policy and the tax administration reform is available.

\section{Status of structural conditionality from earlier programs}

Virtually all structural measures included in the Stand-By Arrangement, which expired in September 2001, were implemented. A benchmark on the establishment of best practice anti-money laundering rules was missed because of a postponement in the scheduled FSAP mission, that was expected to provide technical advice. The benchmark on the reconciliation of provincial expenditure was only partially met because of limited institutional capacity in managing both the devolution initiative and revising accounting procedures to include the newly created district administrations. The structural reform program in the PRGF program includes a series of steps to improve expenditure reconciliation over the program period.

\section{Structural areas covered by World Bank and other donors' lending and conditionality}

World Bank program lending for FY 2001/02, as for the previous fiscal year, was delivered under a onetranche Structural Adjustment Credit (SAC). The IDA-financed US\$500 million SAC II disbursement (in June 2002) was conditional on (a) accelerating power sector reforms with a view to restoring the sector's financial viability; (b) revamping the tax administration system to improve governance and increase revenues; (c) improving the policy framework in the oil and gas sectors to attract domestic and foreign investment; (d) improving the effectiveness in the delivery of social services through civil service reforms, and enhanced transparency and accountability in the use of public resources; (e) accelerating the tmplementation of the Education Sector Reforms Action Plan and the National Health Policy; and (f) establishing monitoring and evaluation systems to assess progress in the implementation of the poverty reduction strategy. The World Bank also approved (in July 2002) \$ACs for two provinces (Sindh and North West Frontier Province) totaling US $\$ 190$ million supporting provincial reform strategies to improve fiscal transparency, resource management, and strengthen provision of public services by local governments and communities. Conditionality related to the restructuring of three nationalized banks is part of a banking sector project loan approved in October 2001.

4. The AsDB is supporting Pakistan's adjustment effort through various program loans: an Energy Sector Restructuring Program loan (including conditionality leading to the privatization of KESC and two of the corporatized WAPDA entities); a Small and Medium Enterprise Trade Enhancement Finance loan; a Trade, Export Promotion and Industry program; an agricultural policy reform loan, aimed at reducing the government's intervention in agriculture and raising agricultural productivity, and a loan to enhance access to justice, raise the accountability of justice and law enforcement agents, and strengthen the rule of law.

1/ Updated from Country Report No. 02/141. 
42. Staff is concerned that too little progress has been made in recent years in reducing poverty, although quantitative evidence is not yet available. Low levels of growth and job creation, the impact of drought on the rural areas where most of the poor live, as well as continued insufficient provision of basic social services, have been the main culprits in this regard. Staff urges the authorities to speed up the development and monitoring of poverty data and intermediate social ontcome indicators to allow a better and more timely measurement and analysis of poverty developments, and of the efficiency of the various social programs. World Bank analysis indicating that some of the main causes of poverty were the lack of assets, a malfunctioning judicial system, deep-seated gender issues, the degradation of natural resources, and growing vulnerability to tertiary diseases, highlights the need to more forcefully tackle these issues in the context of the full PRSP.

43. Staff concurs with the authorities' proposed macroeconomic policy mix of a monetary policy geared toward keeping inflation low, within a flexible exchange rate regime, and continued fiscal adjustment to bring public debt dynamics on a clear downward path. For the short term, staff believes some tightening of monetary policy may be appropriate, as the recent up-tick in inflation indicates that the rapid growth of broad money may not entirely reflect a sustained increase in money demand. Given the objective of continued reserve accumulation and the need to avoid a large real appreciation of the Pakistani rupee, foreign exchange purchases and sterilization policy will have to be finely calibrated and monetary and price developments be kept under close watch.

44. Regarding the fiscal strategy, staff is concerned about plans to support the restructuring and/or investment programs of various public enterprises with "one-off" budgetary transfers. Unless such restructuring is part of a clearly articulated strategy to privatize or liquidate, staff sees a high risk that a recapitalized public enterprise may again be abused to finance quasi-fiscal activities or to provide the means for outright patronage and political favors. Thus, while the AsDB-supported reform of ADBP is a step in the right direction, staff urges the authorities to explicitly make privatization in the near future the ultimate goal. Similarly, while guaranteeing PIA's borrowing to finance renewal of its fleet may be based on a viable business plan, the recent gains in governance and performance should be locked in through privatization of the company. More generally, there is little doubt that over the coming years more contingent public liabilities will have to be absorbed by the budget. Such liabilities may arise from guarantees on public enterprise borrowing, the nonperforming assets of nationalized banks and public development banks, commodity operations, and the public pension system. The authorities' commendable publication of estimates of contingent public liabilities ahead of each budget has greatly increased transparency on this issue. In the context of the planned move to medium-term budgeting, staff encourages the authorities to more explicitly incorporate the settlement of these liabilities in the budget, and avoid bringing them up ad hoc after the budget has been passed. This would more clearly highlight the constraints under which public finances operate, and ensure that the related hard choices and trade-offs are part of the budget process. 
45. The economic outlook for Pakistan is subject to considerable downside risks. One risk, in view of the historical record of Fund-supported programs in Pakistan, is that the projections underlying the program, which reflect the assumption that the current reforms will continue and will have a strong impact within a relatively short time, may be overly optimistic. Some comfort may be drawn from the stress tests, which indicate that various standard shocks to the baseline, of magnitudes similar to those experienced in the $1990 \mathrm{~s}$, are unlikely to trigger a quick descent into unstable debt dynamics. However, the main danger is that the reform efforts will not be sustained over a sufficiently long period of time, as happened so often in Pakistan's history. In this regard, staff is concerned that, for the second time this year, petroleum taxes have been temporarily lowered to smoothen the impact of surging international oil prices on consumers. This adds to the risks for the budget and weakens the credibility of the rules-based petroleum pricing policy. Staff hopes that the recent election will result in a broadening and deepening of the political consensus for sustaining the reforms, rather than a shift to populist policies. The continued regional tensions and domestic security concerns are another important risk, that could manifest itself in different ways, each requiring the timely enactment of appropriate contingency measures.

46. In view of Pakistan's track record over the last two years, staff is confident that the authorities will be able to hold the program broadly on course, even if such risks were to materialize. Strong reserves and a flexible exchange rate regime should help cushion possible shocks. The recent electricity tariff increases indicate willingness and ability to implement structural reform, even if unpopular. Staff supports the request for the three waivers. The end-June 2002 performance criterion on CBR revenue was missed largely for exogenous reasons, as already expected during the previous review, and the criterion on bringing KESC to the point of sale was not observed essentially because of lack of investor interest, something largely outside the control of the government. Staff fully supports the authorities' decision to withdraw the GST on pharmaceuticals, because maintaining this extremely unpopular measure would have sharply weakened public support for the overall adjustment effort, and because the technical complications arising from exempting lifesaving drugs had made the tax unworkable and open to abuse. Strong corrective measures are in place: (a) a strong tax policy and tax administration reform package was put in place with the last budget and its implementation is on track; (b) measures to improve KESC's financial performance and enhance monitoring and accountability of its performance have been put in place and could form the basis for a restructuring effort under a private management contract should privatization prove impossible; and (c) a set of additional tax measures is to be completed by end-October 2002 , as a prior action for Board consideration of this review, to replace the revenue lost through the withdrawal of the GST on medicines and the temporary lowering of petroleum surcharges in September and early October 2002. On this basis, staff recommends the granting of the requested waivers and modification of performance criteria to allow completion of the third review under the PRGF arrangement.

47. It is recommended that the next Article IV consultation with Pakistan be held on the 24-month cycle, subject to the provisions of the decision on consultation cycles approved on July $15,2002$. 
Figure 1. Pakistan: Output and Inflation, 1995/96-2002/03

Real and Agricultural GDP 1/

(Annual percentage change)

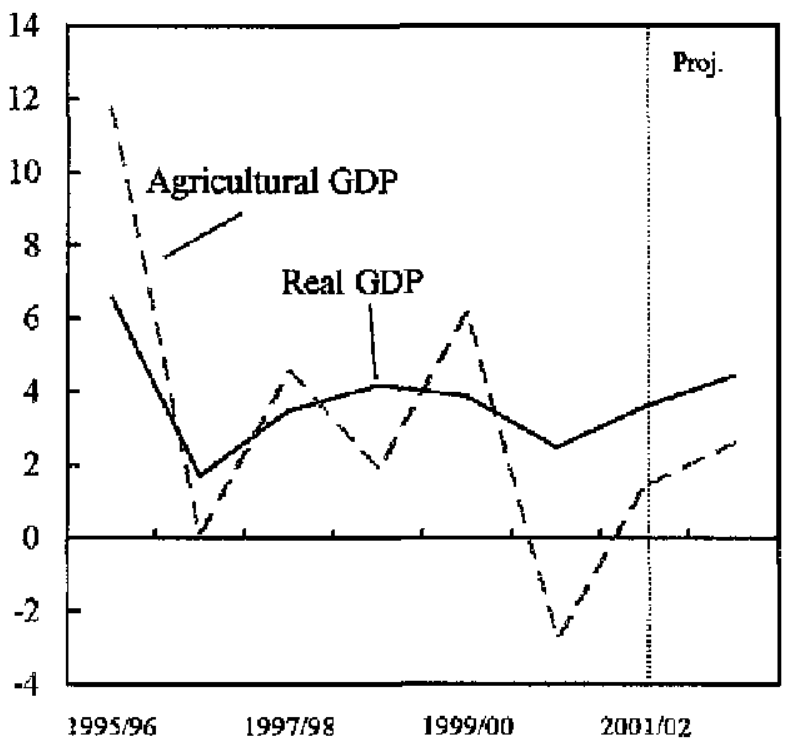

CPI Inflation 3/

(Year-on-year percentage change)

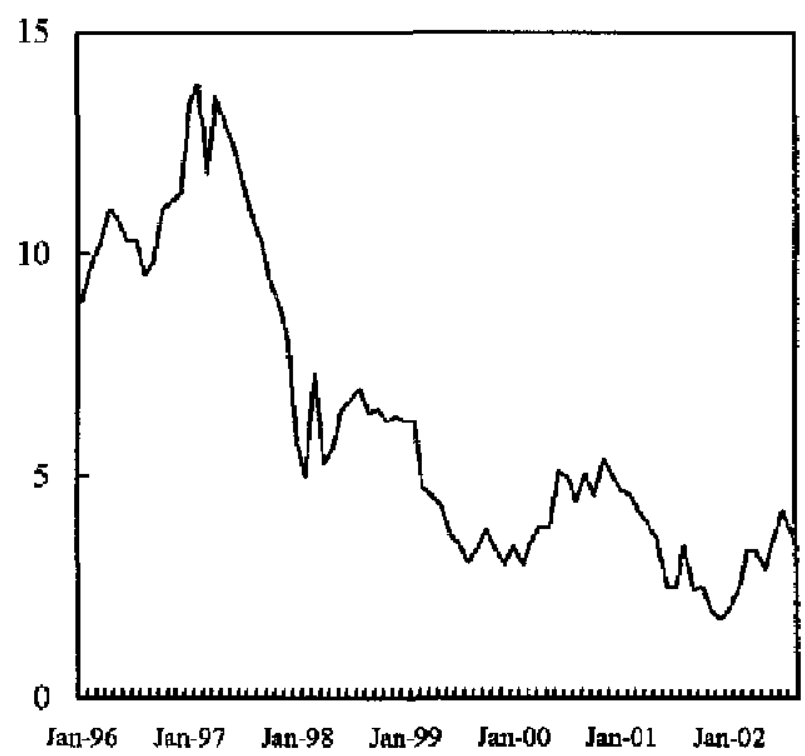

Manufacturing Production Index 2/

(Year-on-year percentage change)

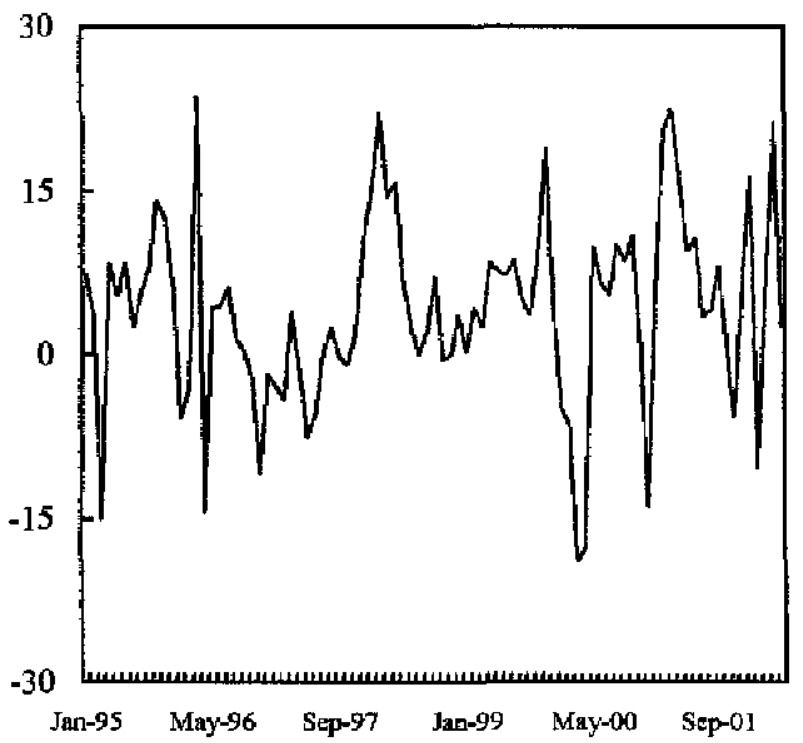

CPI Inflation 3/

(Year-on-year percentage change)

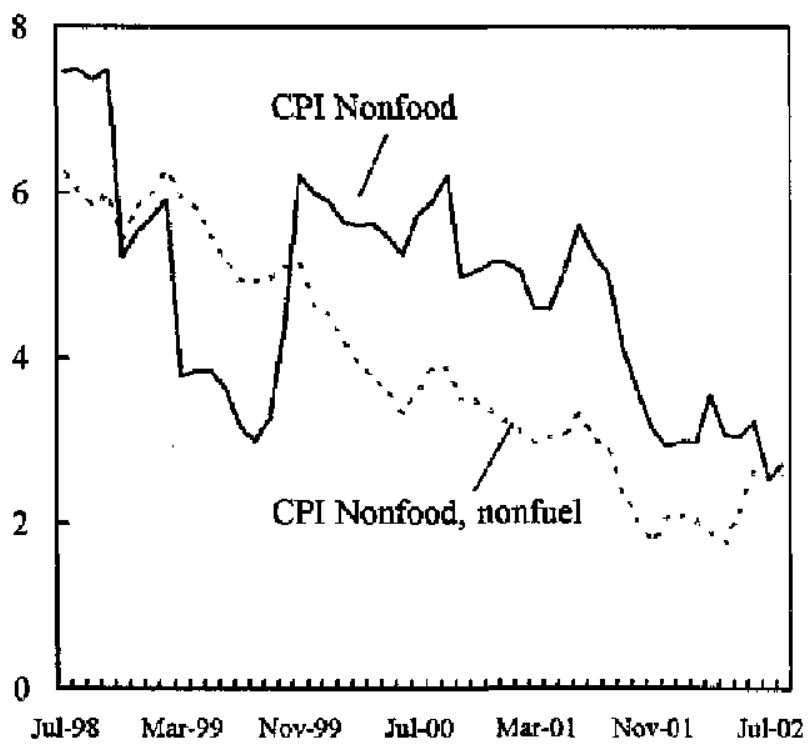

Sources: Data provided by the Pakistani authorities.

1/ Last observation: projection for 2002/03.

2/ Last observation: May 2002.

3/ Last observation: August 2002. 
Figure 2. Pakistan: External Sector Developments, 1994/95-2002/03

Exports 1/

(Year-on-year percentage change)

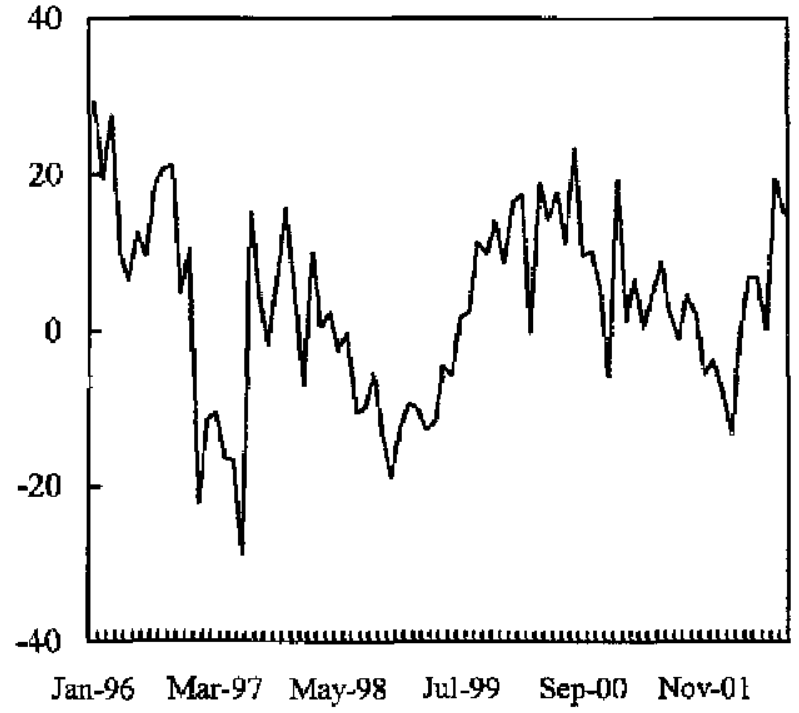

Current Account 2/

(In percent of GDP)

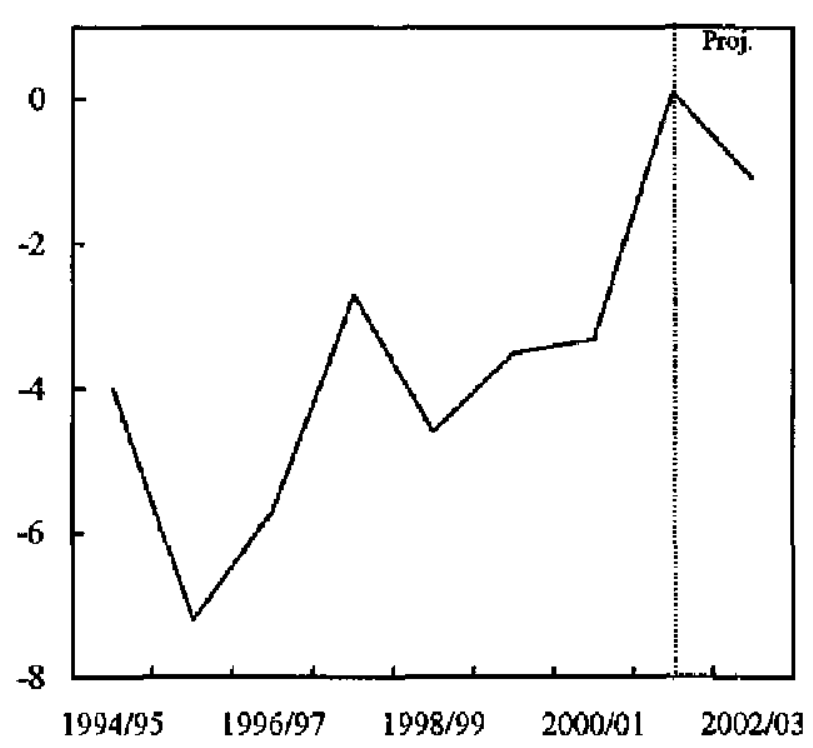

Imports $1 /$

(Year-on-year percentage change)

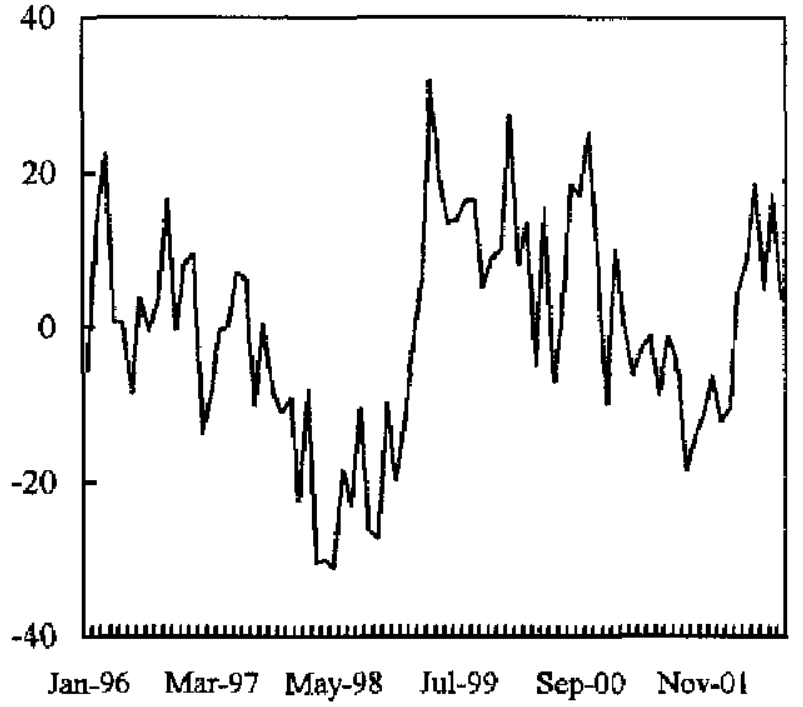

Gross Official Reserves 3/

(In bilitions of U.S. dollars)



Sources: Data provided by the Pakistani authorities.

I/ Customs basis. Last observation: August 2002.

2/ Excluding official transfers. Last observation: projection for 2002/03.

3/ Excluding gold, foreign deposits held with SBP, short-term swap and forward commitments. Last observation: September 11, 2002. 
Figure 3. Pakistan: Exchange Rate and Stock Market Developments, 1995-2002

Pakistani rupee per U.S. Dollar $1 /$

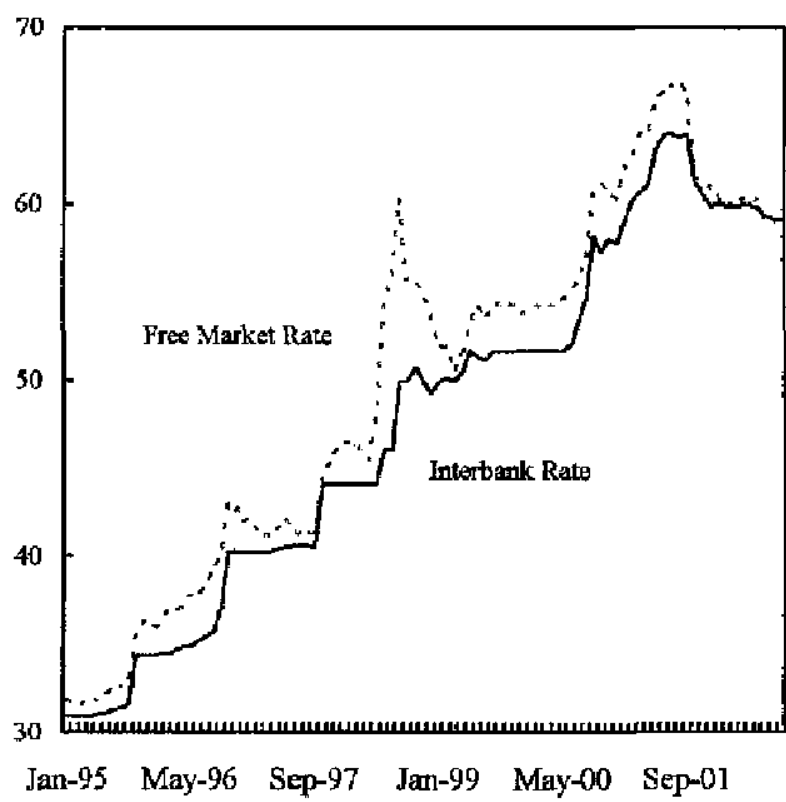

Free Market Premium 1/

(In percent)



Nominal and Real Effective Exchange Rates 2/

$(1990=100)$

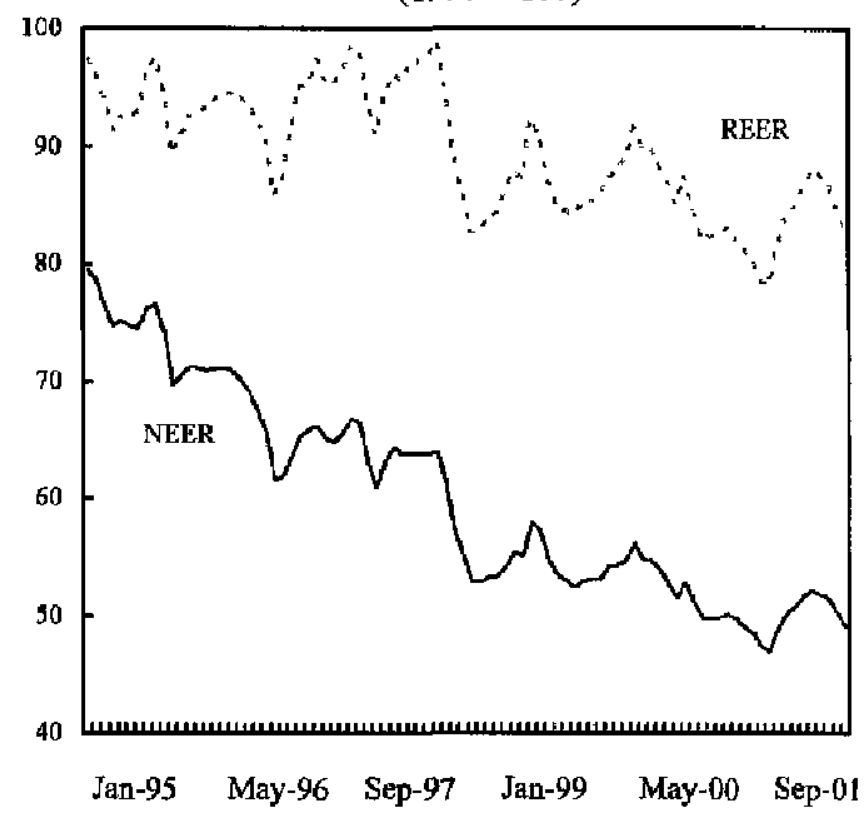

Karachi Stock Exchange Index 1/

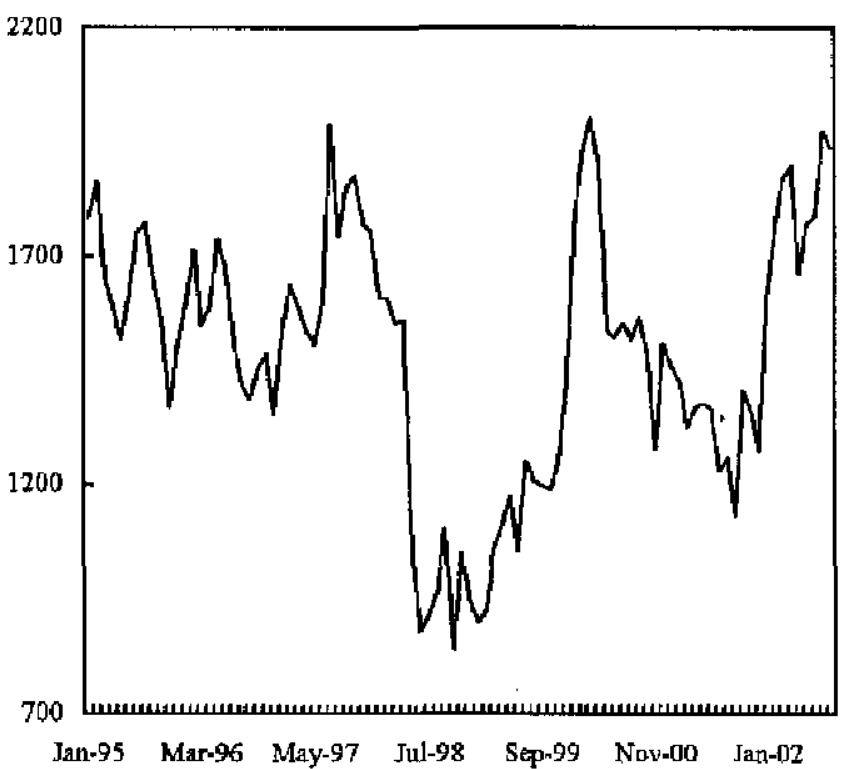

Sources: Data provided by Pakistani authorities; and Fund staff estimates.

1/ Last observation: September 11, 2002

2/ Last observation: June 2002. 
Figure 4. Pakistan: Monetary Developments, 1996-2002

Interest Rates 1/

(In percent)

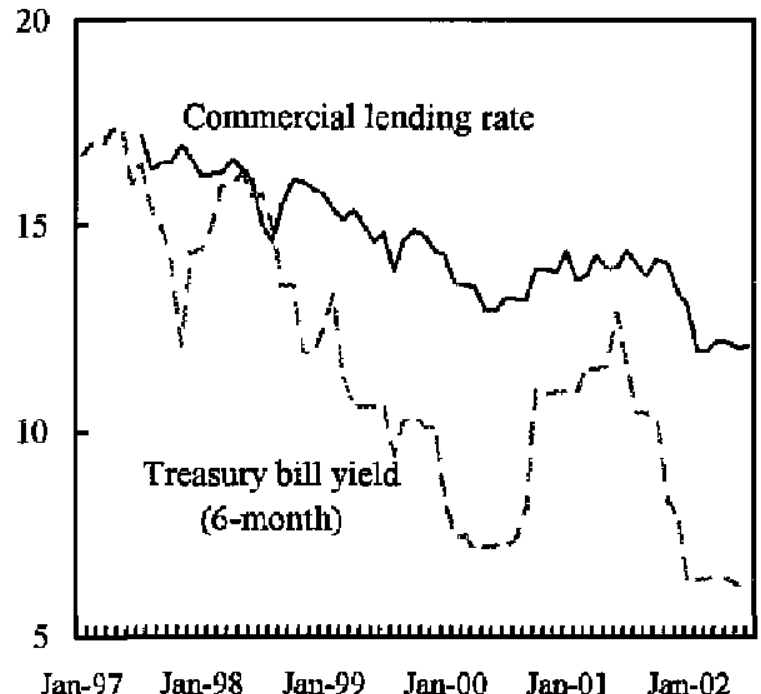

Broad Money 2/

(Year-on-year percentage change)

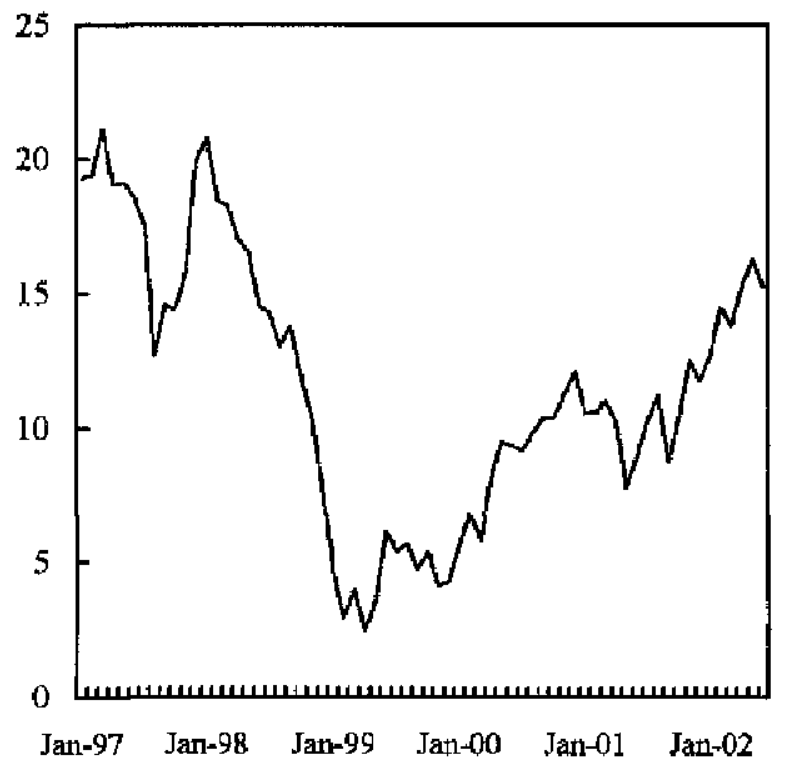

Ratios 2/

(In percent)

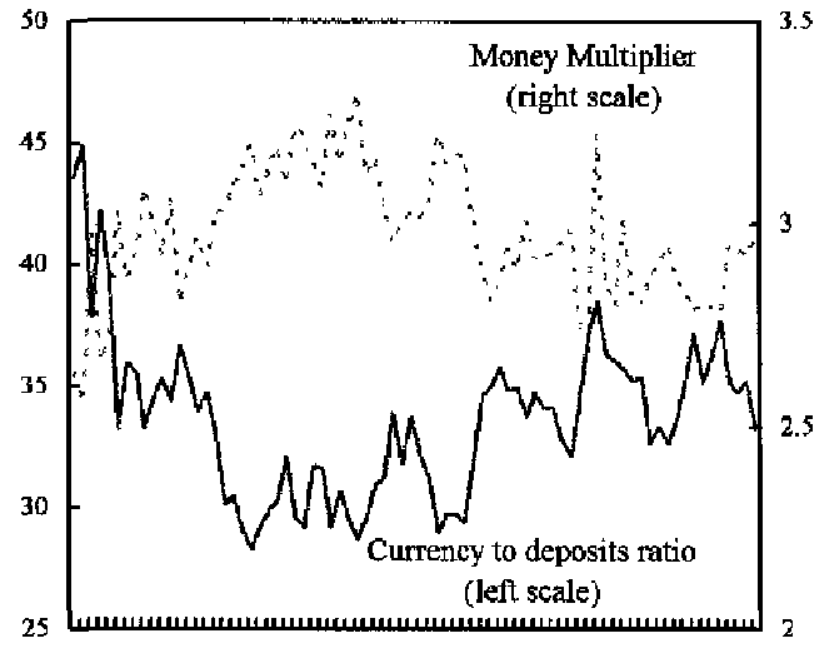

Jan-96 Jan-97 Jan-98 Jan-99 Jan-00 Jan-01 Jan-02
Reserve Money $2 f$

(Year-on-year percentage change)

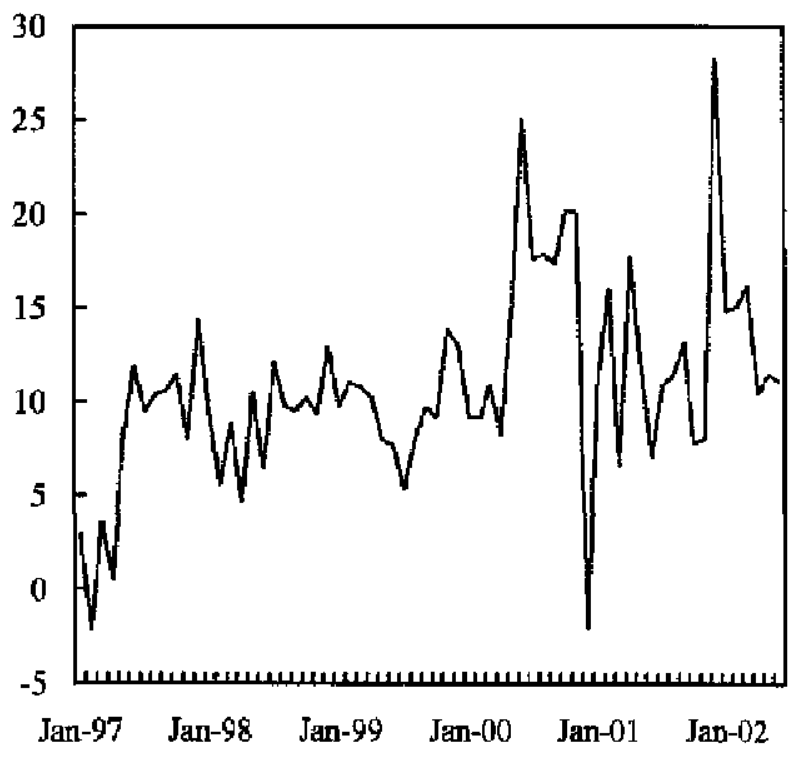

Sources: Data provided by the Pakistani authorities.

1/ Last observation: July 2002.

2/ Last observation: June 2002. 
Figure 5. Pakistan: Fiscal Developments, 1993/94-2002/03 1/

Fiscal Balance Excluding Grants (In percent of GDP)

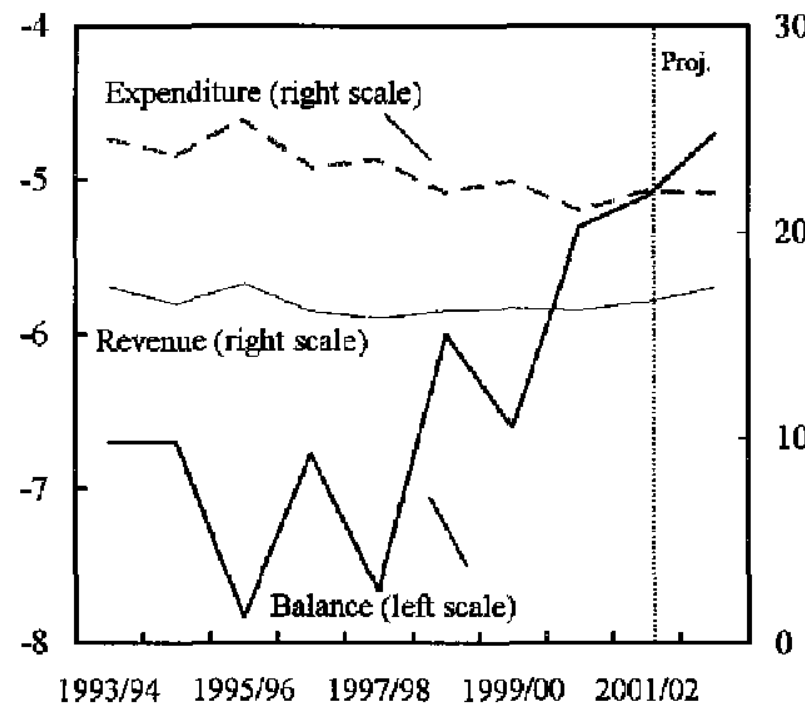

Composition of Revenue

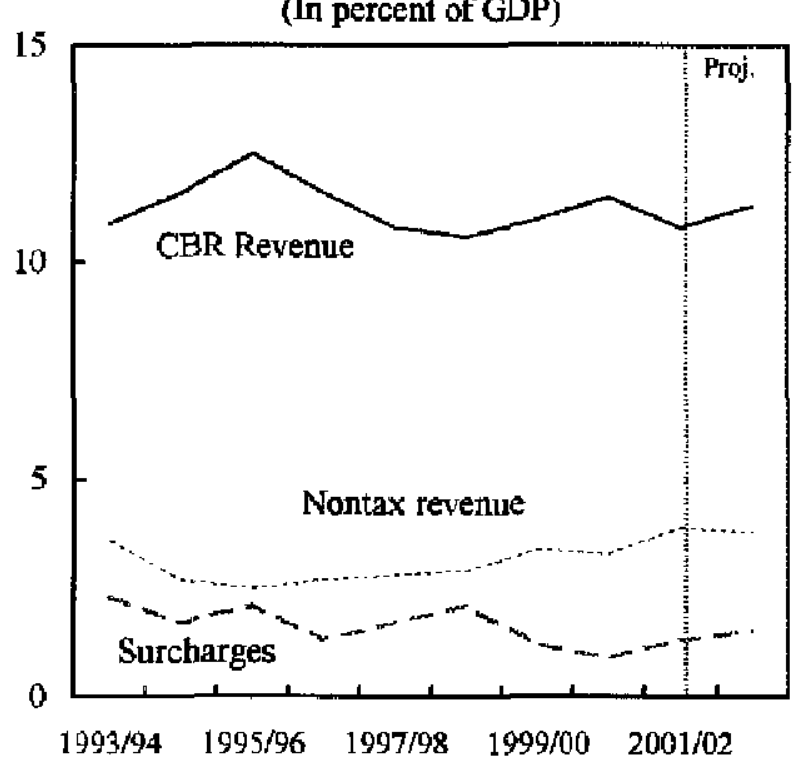

Composition of Debt (In percent of GDP)

30

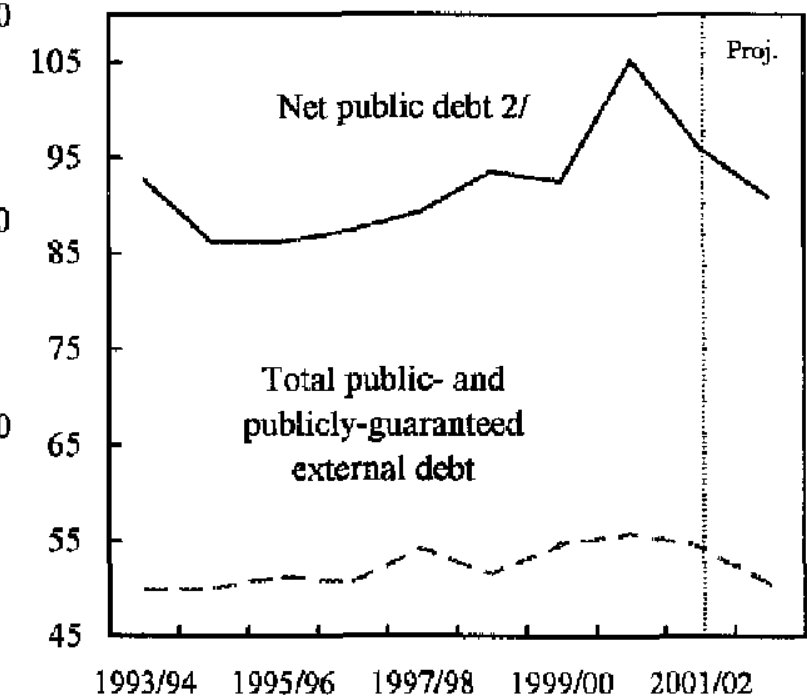

Composition of Expenditure

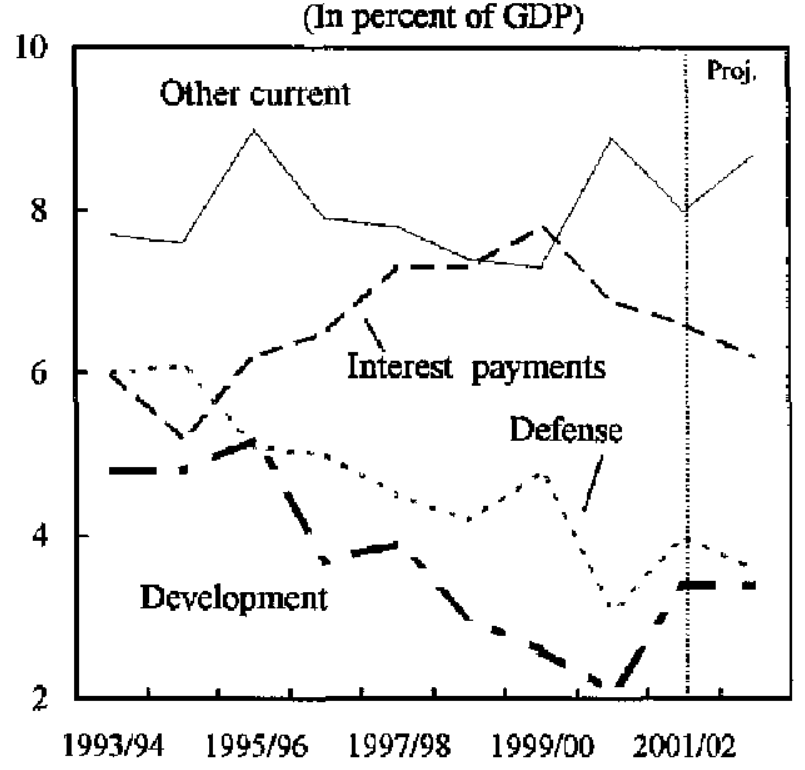

Sources: Data provided by the Pakistani authorities.

1/ Last observation: projection for 2002/03.

2/ Net public debt is the sum of net domestic government debt and external public- and publicly-guarănteed debt. 
Figure 6. Pakistan: Recent Financial Market Developments 2001-2002 1/

Exchange Rate Premium in Kerb Market Over Interbank Market

(Pakistani rupee per U.S. Dollar, in percent)

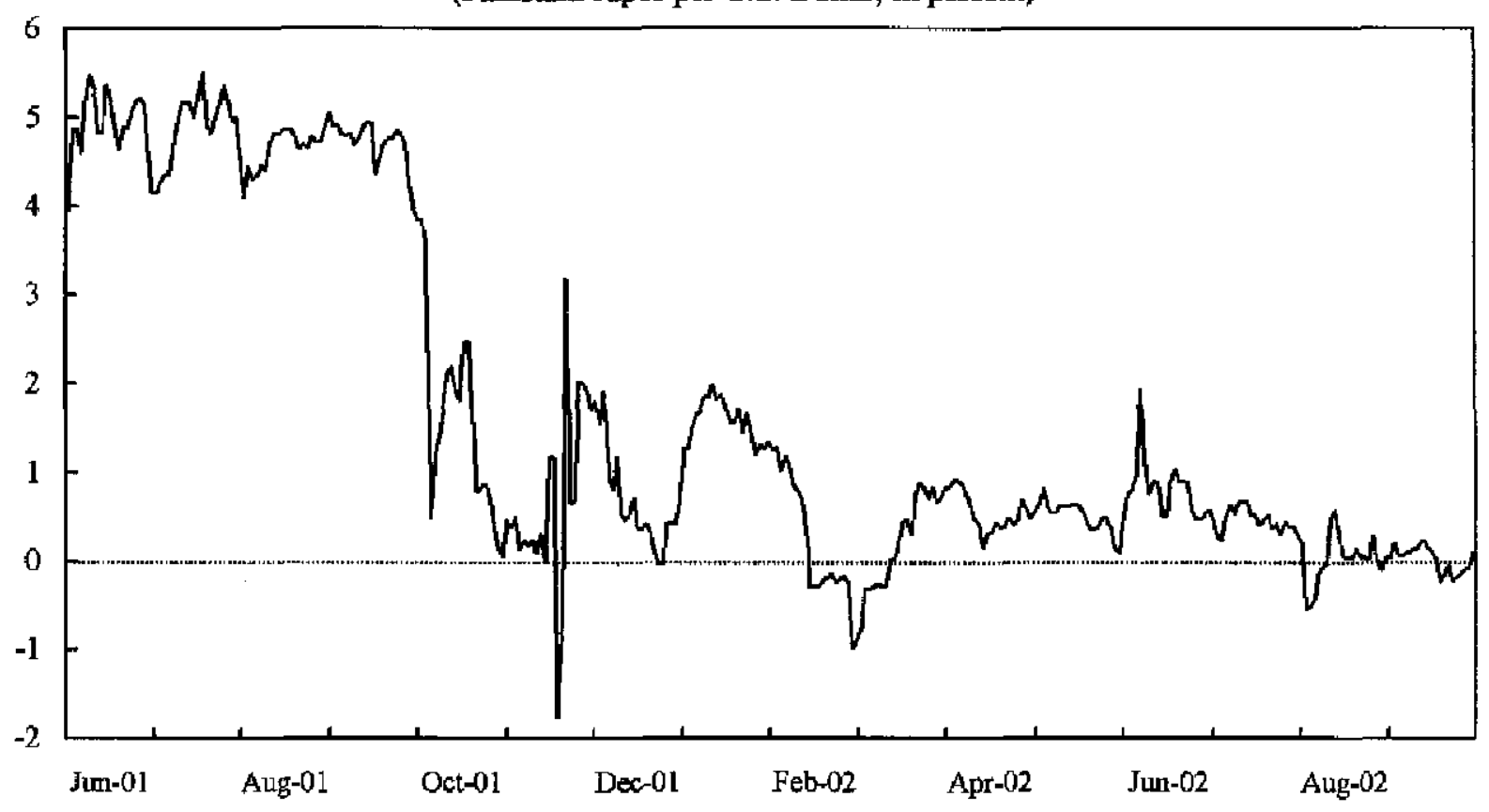

Spread Over Generic U.S. Treasury Bond $2 /$

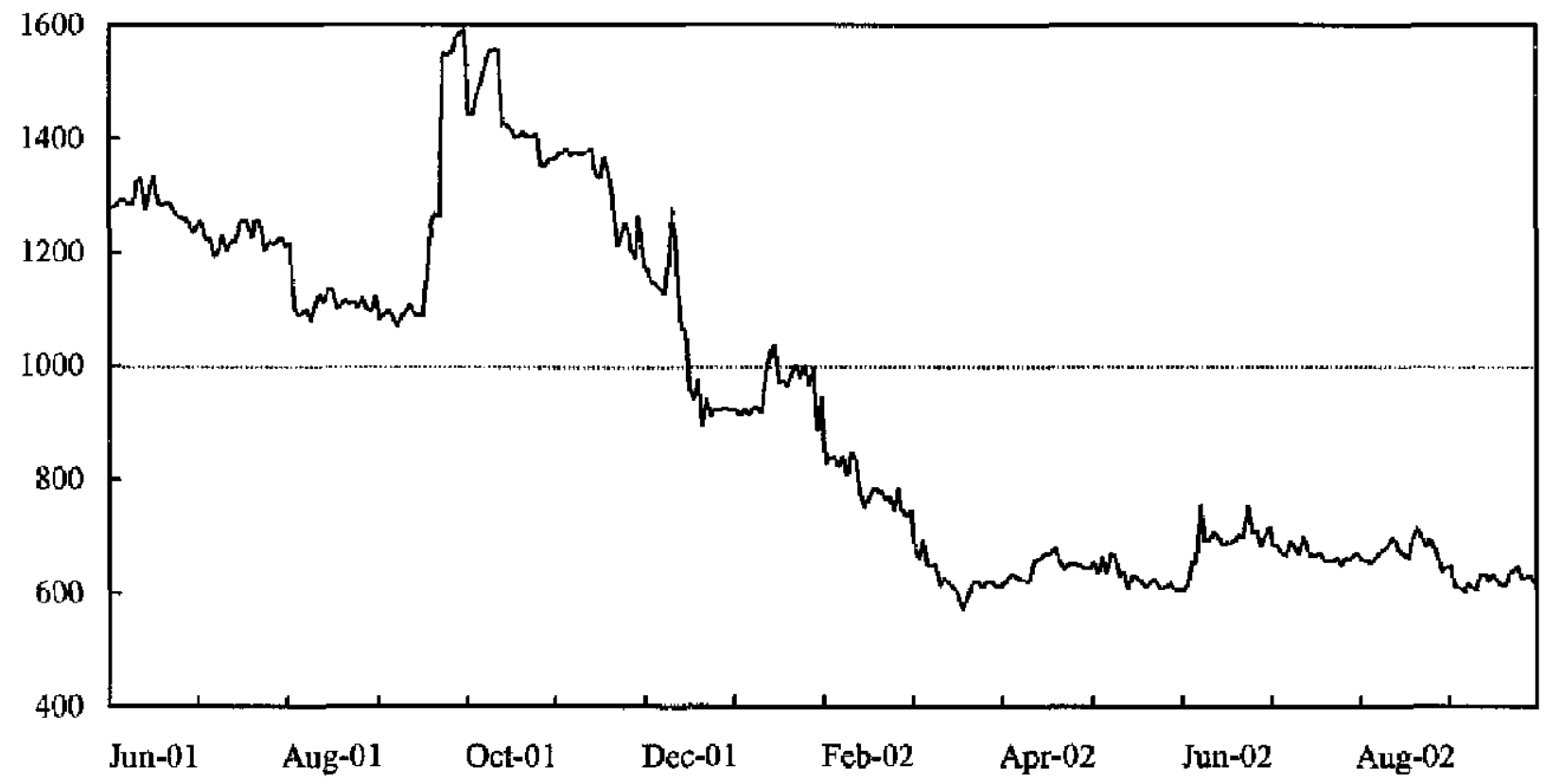

Sources: Data provided by Pakistani authorities; and Datastream.

1/ First observation: June 1, 2001; last observation: September 11, 2002.

2/ Calculated for Pakistan Islamic Republic 10 percent bond maturing on December 13, 2005. 
Table 1. Pakistan: Medium-term Macroeconomic Framework, 2000/01-2006/07 (continued)

Prog. $1 /$ Est. Rev. Prog. Proj.

$2000 / 012001 / 02 \quad 2001 / 02 \quad 2002 / 03 \overline{2003 / 042004 / 052005 / 062006 / 07}$

Output and prices

Real GDP at factor costs

Real GDP at market prices

Partner country demand

Consumer prices (p.a.)

Pakistani rupees per U.S. dollar (p.a.)

Savings and investment

Gross national savings

Government

Nongovermment $2 /$

Gross capital formation

Government $3 /$

Nongovermment 2/

Public finances

Revenue (including grants)

Expenditure 4/5/

Overall balance (including grants) $5 /$

Primary balance (including grants)

Net public debt 6 /

Net domestic government debt $7 /$

Implicit interest rate on public debt (in percent) 8/

Monetary sector $9 /$

Net foreign assets

Net domestic assets

Of which: credit to the private sector

Of which: net claims on the government $5 /$

Broad money

Six-month treasury bill rate (in percent, p.a.)

External sector

Merchandise trade balance

Merchandise exports

Merchandise imports

Current account excluding official transfers

Current account including official transfers
(Annual changes in percent)

\begin{tabular}{rrrrrrrr}
2.5 & 3.3 & 3.6 & 4.5 & 5.0 & 5.0 & 5.0 & 5.0 \\
2.7 & 3.4 & 4.4 & 4.9 & 5.1 & 5.1 & 5.1 & 5.1 \\
3.1 & 1.5 & 1.7 & 2.5 & 3.4 & 3.8 & 3.8 & 3.6 \\
4.4 & 3.0 & 2.7 & 4.0 & 4.0 & 4.0 & 4.0 & 4.0 \\
12.8 & $\ldots$ & 5.2 & $\ldots$ & $\ldots$ & $\ldots$ & $\ldots$ & $\ldots$ \\
\multicolumn{7}{c}{ (In percent of GDP) }
\end{tabular}

$\begin{array}{rrrrrrrr}14.0 & 15.4 & 16.4 & 15.2 & 16.0 & 16.4 & 17.0 & 17.1 \\ -1.5 & 0.2 & 0.2 & 0.1 & 1.7 & 1.7 & 1.8 & 1.9 \\ 15.6 & 15.2 & 16.1 & 15.1 & 14.3 & 14.7 & 15.2 & 15.3 \\ 15.9 & 15.2 & 13.9 & 15.0 & 16.0 & 16.5 & 17.0 & 17.2 \\ 2.6 & 3.4 & 3.4 & 3.5 & 4.1 & 4.2 & 4.3 & 4.4 \\ 13.3 & 11.8 & 10.5 & 11.5 & 11.9 & 12.3 & 12.7 & 12.8\end{array}$

(In percent of GDP)

$\begin{array}{rrrrrrrr}17.4 & 19.3 & 18.8 & 18.6 & 18.5 & 18.5 & 18.7 & 18.7 \\ 21.4 & 22.7 & 23.0 & 21.9 & 20.8 & 21.0 & 21.2 & 21.2 \\ -4.1 & -3.3 & -4.2 & -3.3 & -2.3 & -2.5 & -2.5 & -2.5 \\ 2.8 & 3.6 & 3.7 & 2.9 & 3.4 & 2.7 & 2.3 & 1.9 \\ 103.8 & 94.1 & 96.2 & 91.2 & \mathbf{8 3 . 7} & 77.9 & 72.6 & 68.0 \\ 42.6 & 41.8 & 42.9 & 40.5 & 37.7 & 35.3 & 33.7 & 32.3 \\ 8.6 & 7.3 & 6.9 & 7.0 & 6.9 & 6.8 & 6.7 & 6.6\end{array}$

(Annual changes in percent of initial stock of broad money)

$\begin{array}{rrrrllll}5.1 & 3.4 & 13.4 & 5.1 & \ldots & \ldots & \ldots & \ldots \\ 3.9 & 5.7 & 1.8 & 4.4 & \ldots & \ldots & \ldots & \ldots \\ 3.5 & 5.1 & 2.4 & 5.2 & \ldots & \ldots & \ldots & \ldots \\ -3.3 & -2.1 & 1.4 & -1.9 & \ldots & \ldots & \ldots & \ldots \\ 9.0 & 9.1 & 15.2 & 9.5 & \ldots & \ldots & \ldots & \ldots \\ 10.4 & \ldots & 8.1 & \ldots & \ldots & \ldots & \ldots & \ldots\end{array}$

(In percent of GDP)

$\begin{array}{rrrrrrrr}-2.2 & -1.4 & -0.6 & -0.9 & -0.8 & -0.8 & -0.8 & -0.9 \\ 15.2 & 14.9 & 15.0 & 14.9 & 14.8 & 14.9 & 14.9 & 14.9 \\ 17.4 & 16.4 & 15.6 & 15.8 & 15.7 & 15.7 & 15.8 & 15.8 \\ -3.3 & -2.3 & 0.1 & -1.1 & -1.3 & -1.1 & -1.0 & -1.0 \\ -1.9 & 0.2 & 2.5 & 0.2 & 0.0 & -0.1 & 0.0 & -0.1\end{array}$


Table 1. Pakistan: Medium Term Macroeconomic Framework, 2000/01-2006/07 (concluded)

\begin{tabular}{|c|c|c|c|c|c|c|c|c|}
\hline \multirow[b]{3}{*}{ External public- and publicly-guaranteed debt } & \multirow{3}{*}{$\begin{array}{r}2000 / 01 \\
\quad 318.4\end{array}$} & $\begin{array}{l}\text { Prog. 1/ } \\
001 / 02\end{array}$ & \multirow[t]{2}{*}{$\begin{array}{r}\text { Est. } \\
2001 / 02\end{array}$} & \multirow[t]{2}{*}{$\begin{array}{r}\text { Rev. Prog. } \\
2002 / 032\end{array}$} & \multicolumn{4}{|c|}{$\frac{\text { Proj. }}{0520}$} \\
\hline & & \multicolumn{5}{|c|}{ (In percent of exports of goods and nonfactor services) } & & \\
\hline & & 316.9 & 300.2 & 286.6 & 268.1 & 248.2 & 227.8 & 210.3 \\
\hline Debt service 10f & 28.2 & 36.5 & 33.9 & 33.5 & 31.3 & 27.4 & 24.5 & 22.0 \\
\hline Implicit interest rate (in percent) $11 /$ & 4.4 & 4.3 & 3.9 & 3.9 & 4.1 & 4.0 & 3.8 & 3.6 \\
\hline Grass reserves (in millions of U.S. dollars) $12 /$ & 1,679 & 2,647 & 4,329 & 5,292 & 5,736 & 6,370 & 7,008 & 7,647 \\
\hline In months of next year imports of goods and services & 1.7 & 2,5 & 4,0 & 4,6 & 4.7 & 4,9 & 5,1 & 5.2 \\
\hline In percent of short-term external debt 13 / & 23.7 & 63.4 & 71.7 & 103.4 & 149.8 & 181.8 & 209.9 & 246,5 \\
\hline \multicolumn{9}{|l|}{ Mernorandum items: } \\
\hline Real effective exchange rate (percentage change) & -2.6 & & -1.2 & & & & & \\
\hline Terms of trade (percentage change) & -1.6 & 0.3 & -0.9 & 0.9 & 1.9 & 2.0 & 1.5 & 0.9 \\
\hline Real per-capita GDP (percentage change) & 0.5 & 1.1 & 2.2 & 2.6 & 2.9 & 2.8 & 2.8 & 2.8 \\
\hline GDP at market prices (in billions of Pakistani nupees) & 3,416 & 3,695 & 3,727 & 4,063 & 4,440 & 4,852 & 5,301 & 5,792 \\
\hline
\end{tabular}

Source: Data provided by the Pakistani authorities; Fund staff and World Economic Outlook.

1/ Program underlying the quantitative performance criteria for end-June 2002 as set during the first review (EBS/02/43).

$2 /$ Includes public sector enterprises.

3/ Expenditures included in the Publtc Sector Development Program.

4/ Including the statistical discrepancy.

5/ Including KESC recapitalization and CBR bonds in 2001/02.

6/ Defined as the sum of net domestic government debt and external public- and publicly-guaranteed debt.

7/ Gross domestic government debt, including U.S. dollar bonds, net of government deposits with the banking system.

8/ The implicit interest rate on public debt is calculated as interest payments in percent of the end-of-period debt stock of the previous year.

9/ Program data for 2001/02 and revised program for 2002/03 are evaluated at program exchange rates.

$10 /$ Including interests on short-term debt.

11/ The implicit interest rate on external public debt is calculated as interest payments in percent of the average stock of debt of the current and previous fiscal year.

12/ Excluding gold, foreign deposits held with the SBP, and net of outstanding short-term foreign currency swap and forward contracts.

13/ Short-term debt is defined on the basis of remaining maturity. 
Table 2. Pakistan: Balance of Payments, 2000/01-2003/04

(In millions of U.S. dollars)

$$
\text { Q1 } \quad \text { Q2 } \quad \text { Q3 } \quad \text { Q4 }
$$

Prog. $\quad$ Est. Rev. Prog. Rev. Prog. Rev, Prog. Rev. Prog. Rev. Prog. Proj.



\begin{tabular}{|c|c|c|c|c|c|c|c|c|c|}
\hline Current account (excluding official transfers) & $-1,951$ & $-1,364$ & 32 & 99 & -261 & -358 & -239 & -759 & -918 \\
\hline Current account balance (including official transfers) & $-1,112$ & 127 & 1,500 & 358 & -9 & -128 & -56 & 164 & .35 \\
\hline Trade balance & $-1,258$ & -866 & -360 & -101 & -176 & -214 & -97 & -588 & -603 \\
\hline Exports fo.b. & 8,934 & 8,914 & 9,133 & 2,426 & 2,404 & 2,484 & 2,550 & 9,864 & 10,633 \\
\hline Imports f.o.b. & $-10,202$ & $-9,780$ & $-9,493$ & $-2,527$ & $-2,580$ & $-2,698$ & $-2,647$ & $-10,452$ & $-11,236$ \\
\hline Services (net) & $-3,143$ & $-2,957$ & $-2,621$ & -655 & -658 & -713 & -691 & $-2,718$ & $-3,011$ \\
\hline Of which: interest payments & $-1,657$ & $-1,543$ & $-1,573$ & -343 & -447 & -322 & -425 & $-1,536$ & $-1,522$ \\
\hline Private transfers (net) & 2,450 & 2,459 & 3,013 & 855 & 573 & 569 & 550 & 2,547 & 2,696 \\
\hline Official transfers (net) 1 / & 839 & 1,491 & 1,468 & 259 & 252 & 230 & 182 & 923 & 883 \\
\hline Of which: Saudi Oil Facitity & 683 & 609 & 579 & 164 & 161 & 159 & 158 & 642 & 628 \\
\hline Of which: additional grant pledges & $\ldots$ & 767 & 742 & 73 & 70 & 49 & 4 & 197 & 111 \\
\hline Capital account & -623 & $-2,526$ & $-2,234$ & -564 & -591 & -519 & -376 & $-2,051$ & $-1,980$ \\
\hline Public medium- and long-term capital & -652 & -962 & $-1,495$ & -577 & -493 & -189 & -171 & $-1,429$ & $-1,375$ \\
\hline Project and nonproject loans & -332 & -781 & -864 & -175 & -171 & -153 & -139 & -637 & .797 \\
\hline Distursements & 1,463 & 738 & 643 & 186 & 186 & 186 & 186 & 744 & 697 \\
\hline Of which nonproject financing & 678 & 0 & 0 & 0 & 0 & 0 & 0 & 0 & 0 \\
\hline Amortization & $-1,795$ & $-1,519$ & $-1,507$ & -361 & -357 & -339 & -325 & $-1,381$ & $-1,494$ \\
\hline Commercial banks and IDB (net) & -76 & -224 & -224 & -14 & -114 & .15 & -15 & -158 & -33 \\
\hline Other & -244 & 44 & -407 & -388 & -208 & -21 & -17 & -634 & .545 \\
\hline Public sector short-term (net) & -59 & .725 & $-1,062$ & 46 & -75 & 23 & -44 & -51 & -618 \\
\hline Private mediun- and long-term & 343 & .182 & -95 & .77 & 56 & 35 & 18 & 32 & 403 \\
\hline Of which: FDI & 322 & 355 & 369 & 100 & 120 & 80 & 60 & 360 & 500 \\
\hline Private short-term (including errors \& omissions) $2 /$ & -256 & -658 & 418 & 44 & -79 & -388 & -179 & -602 & -390 \\
\hline Overall balance (before debt relief ) & $-1,735$ & $-2,400$ & -734 & -206 & -600 & -648 & -432 & $-1,886$ & $-2,015$ \\
\hline Finatncing & 1,735 & 2,400 & 734 & 206 & 600 & 648 & 432 & 1,885 & 2,015 \\
\hline Reserve assets (increase -) & $-1,088$ & $-1,284$ & $-3,079$ & -771 & -243 & -151 & -200 & $-1,365$ & -819 \\
\hline State Bank of Pakistan (including FE-25s) & -729 & $-1,048$ & $-2,716$ & -680 & -152 & -60 & -109 & $-1,002$ & -519 \\
\hline Deposit money banks & -359 & -236 & -363 & 91 & -91 & -91 & -91 & -363 & -300 \\
\hline Fund repurchases & -194 & -195 & -194 & -84 & -60 & -108 & -72 & -324 & -389 \\
\hline Net exceptional financing & 3,017 & 3,878 & 4,007 & 1,061 & 903 & 906 & 704 & 3,575 & 3,223 \\
\hline Arrears (increase + ) & -525 & 0 & 0 & 0 & 0 & 0 & 0 & 0 & 0 \\
\hline Rescheduling $3 /$ & 1,587 & 1,251 & 1,210 & 271 & 313 & 246 & 194 & 1,025 & 1,031 \\
\hline Of which: Private Sector Involvement & 0 & 0 & 0 & 0 & 100 & 0 & 0 & 100 & 100 \\
\hline Rollover of foreign deposits with banking system $4 /$ & 1,676 & 1,189 & 1,314 & 250 & 150 & 300 & 200 & 900 & 500 \\
\hline Program finamcing from IFIs & 279 & 1,438 & 1,367 & 490 & 390 & 310 & 260 & 1,451 & 1,442 \\
\hline World Bark & 0 & 581 & 698 & 200 & 100 & 100 & 150 & 550 & 550 \\
\hline AsDE & $\mathbf{0}$ & 370 & 185 & 175 & 180 & 100 & 0 & 455 & 450 \\
\hline EMF & 279 & 488 & 484 & 115 & 110 & 110 & 110 & 446 & 442 \\
\hline Privatization receipts & 0 & 0 & 117 & so & 50 & 50 & 50 & 200 & 250 \\
\hline Financing gap & 0 & 0 & 0 & 0 & 0 & 0 & 0 & 0 & 0 \\
\hline & \multicolumn{9}{|c|}{ (In percent of GDP) } \\
\hline \multicolumn{10}{|l|}{ Memorandum items: } \\
\hline Current account (excluding official transfers) & -3.3 & -2.3 & 0.1 & 0.1 & -0.4 & -0.5 & -0.4 & -1.1 & -1.3 \\
\hline Current account balance (including official transfers) & -1.9 & 0.2 & 2.5 & 0.5 & 0.0 & -0.2 & $-0,1$ & 0.2 & 0.0 \\
\hline Exports fo.b. (growth rate, percent) & 9.1 & -0.2 & 2.2 & 10.1 & 3.7 & 16.2 & 193 & 8.0 & 7.8 \\
\hline Intports f.o.b. (growth rate, percemt) & 6.2 & -4.1 & -6.9 & 4.8 & 16.5 & 20.8 & 18.5 & 10.1 & 7.5 \\
\hline End-period gross official reserves 5/ & 1,679 & 2,647 & 4,329 & 5,039 & 5,169 & 5,206 & 5,292 & 5,292 & 5,736 \\
\hline (In weeks of next year imports of goods and nonfactor services) & 7.5 & 11.0 & 17.5 & 19.1 & 19.5 & 19.7 & 20.0 & 20.0 & 20.3 \\
\hline
\end{tabular}

Sources: State Bank of Pakistar; Ministry of Finance; and Fund staff estimates.

1/ Includes a grant from Saudi Arabia in the form of oil that has been agreed on through 2002/03.

2/ Includes repayment of foreign currency deposits held in NBFIs and banks (reschedulings shown as exceptional financing).

3/ Includes rescheduling of bilateral debt in 1999 and 2001, and rescheduling of commercial bank credit and Eurobonds in 1999.

4/ Includes sollover of FE-4S deposits with the banking system, of Kwwait's and U.A.E.'s deposits with the SBP, and Bank of China's deposits with the NBP.

S/ Excluding gold, forejgn curtency deposits held with the SBP, and net of outstanding short-term foreign currency swap and forward contracts. 
Table 3. Pakistan: Consolidated Government Budget, 1999/2000-2003/04

(In billions of Pakistanti rupees)

\begin{tabular}{|c|c|c|c|c|c|c|c|}
\hline & $\begin{array}{l}\text { Prov. A.ct. } \\
1999 / 2000\end{array}$ & $\begin{array}{r}\text { Prov. Act. } \\
200001\end{array}$ & $\begin{array}{r}\text { Prog. } \\
200102\end{array}$ & $\begin{array}{l}\text { Prov. Act. } \\
2001 / 02\end{array}$ & $\begin{array}{l}\text { Prog. 1/ } \\
2002 / 03\end{array}$ & $\begin{array}{c}\text { Rev. Prog. } 2 \\
200203\end{array}$ & $\begin{array}{r}\text { Proj. } \\
2003104\end{array}$ \\
\hline Reverue and grants & 546.0 & 593.5 & 714.4 & 707.2 & 750.0 & 756.7 & 820.7 \\
\hline Revenue & 512.6 & 553.0 & 625,4 & 624.1 & 693.7 & 702.1 & 768.4 \\
\hline Tax revenus & 405.6 & 441.5 & 486.0 & 478.1 & 546.2 & 546.6 & 610.2 \\
\hline Federal & 386.8 & 422.5 & 464.6 & 459.3 & 522.8 & 523.5 & 583.9 \\
\hline CBR revenue & 346.6 & 392.1 & 414.3 & 403.9 & 460.6 & 458.9 & 512.9 \\
\hline Petroleum surcharge & 25.4 & 17,9 & 34.0 & 36.6 & 45.5 & 48.0 & 53.4 \\
\hline Ges surcherge & 13.5 & 12.3 & 15.0 & 17.7 & \pm 5.0 & 15.0 & 15.8 \\
\hline Other & 1.4 & 0.2 & 1.3 & 1.1 & 1.7 & 1.7 & 1.9 \\
\hline Provinajal & 18.8 & 19.0 & 21.4 & 18.8 & 23.4 & 23.1 & 26.3 \\
\hline Nontax revenue & 106.9 & 111.4 & 139.4 & 146.0 & 147.5 & 155.5 & 158.3 \\
\hline Feteral & 90.8 & 91.5 & 117.3 & 124.7 & 125.2 & 132.7 & 134.7 \\
\hline Provincial & 16.1 & 19.9 & 22.1 & 21.3 & 22.3 & 22.7 & 23.6 \\
\hline Grants & 33.4 & 40.5 & 89.0 & 83.1 & 56.3 & 54.6 & 52.3 \\
\hline Expenditure & 709.1 & 717.9 & 837.6 & 826.2 & 872.0 & 891.3 & 924,9 \\
\hline Current expenditure & 626.4 & 645.7 & 705.5 & 700.2 & 735.0 & 751.3 & 746.0 \\
\hline Federal & 477.9 & 479.0 & $\$ 35,4$ & 524.6 & 547.5 & 561.2 & 534.5 \\
\hline Interest payments & 245.1 & 234.5 & 257.0 & 245.3 & 264.0 & 252.1 & 255.1 \\
\hline Domestic & 198.4 & 183.5 & 195.4 & 184.6 & 192.4 & 191.7 & 189.8 \\
\hline Foreign $3 /$ & 46.7 & 51.0 & 61.6 & 60.6 & 71.6 & 60.5 & 65.3 \\
\hline Defense & 150.4 & 104.7 & 149.6 & 149.0 & 146.0 & 146.0 & 145.6 \\
\hline Rumning of the civil goverument & 47.5 & 70.7 & 52.0 & 56.3 & 56.0 & 57.9 & 58.2 \\
\hline Pensions for defense and civil government & & 30.9 & 33.6 & 27.2 & 35.0 & 34.8 & 40.1 \\
\hline Subsidies & 14.7 & 19.9 & 15.7 & 23.7 & 24.0 & 40.4 & 14.2 \\
\hline Grants & 12.6 & 18.1 & 19.6 & 22.8 & 18.7 & 27.5 & 19.7 \\
\hline Other & 7.5 & 0.3 & 7.9 & 0.3 & 3.8 & 2.5 & 1.6 \\
\hline Provincial & 148.5 & 166.7 & 170.1 & 175.6 & 187.6 & 190.1 & 211.6 \\
\hline Development expenditure and net lending & 82.7 & 72.2 & 132.1 & 125.9 & 137.0 & 140.0 & 178.9 \\
\hline Public Sector Development Program & 95.6 & 89.8 & 127.0 & 126.2 & 144.0 & 144.0 & 180.4 \\
\hline Federal & 59.3 & 66.9 & 970 & 98.4 & 96.0 & 96.0 & 122.9 \\
\hline Provincial & 36.3 & 22.9 & 30.0 & 27.8 & 48.0 & 48.0 & 57.5 \\
\hline Net lending & -12.9 & -17.6 & 5.1 & -0.2 & -7.0 & -4.0 & -1.5 \\
\hline Statistical discrepancy ("+" = additional expenditure) & 9.7 & 14.8 & $\ldots$ & -13.0 & $\ldots$ & $\ldots$ & $\cdot \ldots$ \\
\hline Federal govemment & 7.0 & 29.8 & $\ldots$ & 13.9 & $\ldots$ & $\ldots$ & $\ldots$ \\
\hline Provinces & 2.7 & -15.0 & $m$ & -26.9 & $\cdots$ & $\ldots$ & $\cdots$ \\
\hline Budget balance (excluding grants) & -206.3 & -179.7 & -212.3 & -189.1 & -178.3 & -189.2 & -156.5 \\
\hline Budget balance (including grants) & -172.9 & -139.2 & -123.3 & -105.9 & -122.0 & -134.6 & -104.2 \\
\hline KESC recapitalization and CBR bonds 4 / & $\ldots$ & $\cdots$ & $\ldots$ & 52.0 & $\ldots$ & $\ldots$ & ... \\
\hline Augmented budget balance (including grants) & $\ldots$ & $\cdots$ & $\ldots$ & -157.9 & $\cdots$ & $\ldots$ & $\ldots$ \\
\hline Financing & 172.9 & 139.2 & 123.2 & 157.9 & 122.1 & 134.6 & 104.2 \\
\hline External (incl. privatization receipts) & 36.3 & 80.2 & 59.0 & 51.7 & 95.1 & 73.8 & 65.7 \\
\hline Domestic & 136.5 & 59.0 & 57.7 & 97.9 & 14.9 & 48.8 & 28.5 \\
\hline Bank & 39.9 & -33.0 & -6.9 & 12.9 & -29.2 & -29.2 & -14.0 \\
\hline Nonbank & 96.6 & 92.0 & 64.6 & 85.0 & 44.1 & 78.0 & 42.5 \\
\hline Domestic privatization proceeds & 0.0 & 0.0 & 6.5 & 8.4 & 12.0 & 12.0 & 10.0 \\
\hline \multicolumn{8}{|l|}{ Memorandum items: } \\
\hline Expenditure incl. statistical discrepaney and one-off & 718.8 & 732.7 & 837.6 & 865.1 & 872.0 & 891.3 & 9249 \\
\hline Primary balance (including grants) & 72.2 & 95.3 & 133.7 & 139.3 & 142.0 & 117.5 & 150.9 \\
\hline Social-and poverty-related expenditure & 114.4 & 122.3 & 136.4 & 133.5 & 161.0 & 161.0 & 185.1 \\
\hline Nominal GDP at market prices & 3,1472 & $3,416.3$ & $3,695.0$ & $3,726.6$ & $4,063.0$ & $4,063.0$ & $4,440.3$ \\
\hline
\end{tabular}

Source: Pakistani authorities; and Fund staff estimates and projections.

1/ Program as agreed during the second review.

2/ Revised program including PRs 20 billion in additional spending on KESC, ADBP, PIA, and WAPDA, partly offset by savings on foreign interest payments.

$3 /$ Accrued payments. Excludes interest expenditure by the military which is included in the defense allocation.

4/ KESC recapitalization was PRs 32 billion. Bonds for PRs 20 billion were issued for the settlement of excess taxes paid by banks to the CBR on unrealized profits through 2000 . 
Table 4. Pakistan: Consolidated Government Budget, 1999/2000-2003/04

(In percent of GDP; unless otherwise indicated)

\begin{tabular}{|c|c|c|c|c|c|c|c|}
\hline & $\begin{array}{l}\text { Prov. Act. } \\
1999 / 2000\end{array}$ & $\begin{array}{l}\text { Prov. Act, } \\
2000 / 01\end{array}$ & $\begin{array}{r}\text { Prog. } \\
2001 / 02\end{array}$ & $\begin{array}{r}\text { Prov. Act } \\
2001 / 02\end{array}$ & $\begin{array}{l}\text { Prog. 1/ } \\
\text { 2002/03 }\end{array}$ & $\begin{array}{c}\text { Rev, Prog. } 2 r \\
2002 / 03\end{array}$ & $\begin{array}{r}\text { Proj. } \\
2003 / 04\end{array}$ \\
\hline Revenue and grants & 17.3 & 17.4 & 19.3 & 19.0 & 18.5 & 18.6 & 18.5 \\
\hline Revenue & 16.3 & 16.2 & 16.9 & 16.7 & 17.1 & 17.3 & 17.3 \\
\hline Tax revenue & 12.9 & 12.9 & 13.2 & 12.8 & 13.4 & 13.5 & 13.7 \\
\hline Federal & 12.3 & 12.4 & 12.6 & 12.3 & 12.9 & 12.9 & 13.1 \\
\hline CBR revenue & 11.0 & 11.5 & 11.2 & 10.8 & 11.3 & 11.3 & 11.6 \\
\hline Pettoleum surcharge & 0.8 & 0.5 & 0.9 & 1.0 & 1.1 & 1.2 & 1.2 \\
\hline Gas surcharge & 0.4 & 0.4 & 0.4 & 0.5 & 0.4 & 0.4 & 0.4 \\
\hline Other & 0.0 & 0.0 & 0.0 & 0.0 & 0.0 & 0.0 & 0.0 \\
\hline Provincial & 0.6 & 0.6 & 0.6 & 0.5 & 0.6 & 0.6 & 0.6 \\
\hline Nonthx revenue & 3.4 & 3.3 & 3.8 & 3.9 & 3.6 & 3.8 & 3.6 \\
\hline Federal & 2.9 & 2.7 & 3.2 & 3.3 & 3.1 & 3.3 & 3.0 \\
\hline Provincial & 0.5 & 0.6 & 0.6 & 0.6 & 0.5 & 0.6 & 0.5 \\
\hline Grants & 1.1 & 1.2 & 2.4 & 2.2 & 1.4 & 1.3 & 1.2 \\
\hline Expenditure & 22.5 & 21.0 & 22.7 & 22.2 & 21.5 & 21.9 & 20.8 \\
\hline Current expenditure & 19.9 & 18.9 & 19.1 & 18.8 & 18.1 & 18.5 & 16.8 \\
\hline Federal & 15.2 & 14.0 & 14.5 & 14.1 & 13.5 & 13.8 & 12.0 \\
\hline Interest payments & 7.8 & 6.9 & 7.0 & 6.6 & 6.5 & 62 & 5.7 \\
\hline Domestic & 6.3 & $\$ .4$ & $\$ .3$ & 5.0 & 4.7 & 4.7 & 4.3 \\
\hline Foreign $3 /$ & 1.5 & 1.5 & 1.7 & 1.6 & 1.8 & 1.5 & 1.5 \\
\hline Defense & 4.8 & 3.1 & 4.0 & 4.0 & 3.6 & 3.6 & 3.3 \\
\hline Running of the civil government & 1.5 & 2.1 & 1.4 & 1.5 & 1.4 & 1.4 & 1.3 \\
\hline Pensions for defense and civil government & & 0.9 & 0.9 & 0.7 & 0.9 & 0.9 & 0.9 \\
\hline Subsidies & 0.5 & 0.6 & 0.4 & 0.6 & 0.6 & 1.0 & 0.3 \\
\hline Grants & 0.4 & 0.5 & 0.5 & 0.6 & 0.5 & 0.7 & 0.4 \\
\hline Other & 0.2 & 0.0 & 0.2 & 0.0 & 0.1 & 0.1 & 0.0 \\
\hline Provincial & 4.7 & 4.9 & 4.6 & 4.7 & 4.6 & 4.7 & 4.8 \\
\hline Development expenditure and net lending & 2.6 & 2.1 & 3.6 & 3.4 & 3.4 & 3.4 & 4.0 \\
\hline Public Sector Development Program & 3.0 & 2.6 & 3.4 & 3.4 & 3.5 & 3.5 & 4.1 \\
\hline Federal & 1.9 & 2.0 & 2.6 & 2.6 & 2.4 & 2.4 & 2.8 \\
\hline Provincial & 1.2 & 0.7 & 0.8 & 0.7 & 1.2 & 1.2 & 1.3 \\
\hline Net lending & -0.4 & -0.5 & 0.1 & 0.0 & -0.2 & -0.1 & 0.0 \\
\hline Statistical discrepancy $\left({ }^{2+4}=\right.$ additional expenditure) & 0.3 & 0.4 & $\ldots$ & -0.4 & $\ldots$ & $\ldots$ & ... \\
\hline Federal government & 0.2 & 0.9 & $\ldots$ & 0.4 & $\ldots$ & $\ldots$ & $\ldots$ \\
\hline Provinces & 0.1 & -0.4 & $\cdots$ & -0.7 & $\cdots$ & $\ldots$ & $\cdots$ \\
\hline Budget batance (exciuding grants) & -6.6 & -5.3 & -5.7 & -5.1 & -4.4 & -4.7 & -3.5 \\
\hline Budget balance (including grants) & -5.5 & $-4,1$ & -3.3 & -2.8 & -3.0 & -3.3 & -2.3 \\
\hline KESC recapitalization and CBR bonds 4 / & $\ldots$ & $\ldots$ & $\cdots$ & 1.4 & $\ldots$ & $\ldots$ & $\ldots$ \\
\hline Augmented budget balance (including grants) & ... & $\ldots$ & $\ldots$ & -4.2 & $\ldots$ & $\ldots$ & $\ldots$ \\
\hline Financing & 5.5 & 4.1 & 3.3 & 4.2 & 3,0 & 3.3 & 2.3 \\
\hline External & 1.2 & 2.3 & 1.6 & 1.4 & 2.3 & 1.8 & 1.5 \\
\hline Domestic & 4.3 & 1.7 & 1.6 & 2.6 & 0.4 & 1.2 & 0.6 \\
\hline Bank & 1.3 & -1.0 & -0.2 & 0.3 & 0.7 & -0.7 & -0.3 \\
\hline Nonbank & 3.1 & 2.7 & 1.7 & 2.3 & 1.1 & 1.9 & 1.0 \\
\hline Domestic privatization proceeds & 0.0 & 0.0 & 0.2 & 0.2 & 0.3 & 0.3 & 0.2 \\
\hline \multicolumn{8}{|l|}{ Memorandum items: } \\
\hline Expenditure incl. statistical discrepancy and one-off & 22.8 & 21.4 & 22.7 & 23.2 & 21.5 & 21.9 & 20.8 \\
\hline Primary balance (including grants) & 2.3 & 2.8 & 3.6 & 3.7 & 3.5 & 2.9 & 3.4 \\
\hline Social- and poverty-related expenditure & 3.6 & 3.6 & 3.7 & 3.6 & 4.0 & 4.0 & 4.2 \\
\hline Nominal GDP (market prices, billions of Pakistani rupees) & 3,147 & 3,416 & 3,695 & 3,727 & 4,063 & 4,063 & 4,440 \\
\hline
\end{tabular}

Source: Pakistani authorities; and Fund staff estimates and projections.

1/ Program as agreed duritig the second teview.

2 ' Revised program including PRs 20 billion in additional spending on KESC, ADBP, PLA, and WAPDA, partly offset by savings on foreign interest payments.

$3 /$ Accrued payments. Excludes interest expenditure by the military which is included in the defense allocation.

4/ KESC recapitalization was PRs 32 billion. Bonds for PRs 20 billion were issued for the settletnent of excess taxes paid by banks to the CBR on unrealized profits through 2000 . 
Table 5. Pakistan: Monetary Survey, 1999/2000-2002/03

\begin{tabular}{|c|c|c|c|c|c|c|c|c|c|}
\hline & & & \multicolumn{3}{|c|}{ Monetary Program 2001/02 1/ } & \multicolumn{4}{|c|}{ Monetary Program 2002/03 l/ } \\
\hline & & & \multirow{3}{*}{$\begin{array}{r}\text { Mar. } \\
\text { Act. } \\
2002\end{array}$} & \multicolumn{2}{|l|}{ Jun. } & \multirow{3}{*}{$\begin{array}{l}\text { Sep. 3/ } \\
\text { Rev. Prog. } \\
2002\end{array}$} & \multirow{3}{*}{$\begin{array}{l}\text { Dec. 3/ } \\
\text { Rev. Prog. } \\
2002\end{array}$} & \multirow{3}{*}{$\begin{array}{r}\text { Mar. } \\
\text { Rev. Prog. } \\
2003\end{array}$} & \multirow{3}{*}{$\begin{array}{l}\text { Juil. } \\
\text { Proj. } \\
2003\end{array}$} \\
\hline & \multicolumn{2}{|c|}{ Act. } & & Prog. 2/ & Act. & & & & \\
\hline & $1999 / 2000$ & $2000 / 01$ & & 2002 & 2002 & & & & \\
\hline & & \multicolumn{8}{|c|}{ (End-of-period stocks; in billions of Pakistani rupees) } \\
\hline Net foreign assets & -45 & 26 & 149 & 80 & 239 & 277 & 295 & 312 & 322 \\
\hline Net domestic assets & 1,446 & 1,500 & 1,530 & 1,586 & 1,530 & 1,515 & 1,562 & 1,553 & 1,603 \\
\hline $\begin{array}{l}\text { Net claims on government } \\
\text { Of which: }\end{array}$ & 616 & 570 & 546 & 550 & 592 & 586 & 568 & 534 & 558 \\
\hline Net bank borrowing & 532 & 500 & 499 & 507 & 514 & 510 & 498 & 476 & 485 \\
\hline Commodity operations & 107 & 95 & 73 & 70 & 101 & 99 & 94 & 81 & 95 \\
\hline Net claims on nongovernment & 843 & 903 & 942 & 1,013 & 922 & 916 & 980 & 1,007 & 1,032 \\
\hline Private sector & 753 & 802 & 839 & 880 & 838 & 825 & 885 & 907 & 929 \\
\hline Public sector & 90 & 100 & 104 & 133 & 83 & 90 & 95 & 100 & 103 \\
\hline Privatization account & -3 & -3 & -3 & -3 & -3 & -3 & -3 & -3 & -3 \\
\hline Other items, net & -10 & 30 & 44 & 26 & 20 & 16 & 16 & 16 & 16 \\
\hline $\begin{array}{l}\text { Total liquidity (broad money) } \\
\text { Of which: }\end{array}$ & 1,401 & 1,526 & 1,678 & 1,666 & 1,769 & 1,791 & 1,857 & 1,865 & 1,925 \\
\hline \multirow{2}{*}{$\begin{array}{l}\text { J Wrucn. } \\
\text { Pakistani rupee liquidity }\end{array}$} & 1,288 & 1,372 & 1,518 & 1,515 & 1,601 & 1,632 & 1,696 & 1,698 & 1,752 \\
\hline & & \multicolumn{8}{|c|}{ (Changes in percent of stock of broad money at the beginning of the fiscal year) } \\
\hline Net foreign assets & 2.0 & 5.1 & 8.0 & 3.4 & 13.9 & 2.5 & 3.6 & 4.5 & 5.1 \\
\hline Net domestic assets & 7.4 & 3.9 & 2.0 & 5.7 & 2.0 & -0.7 & 2.0 & 1.5 & 4.4 \\
\hline Of which: & & & & & & & & & \\
\hline Net bank borrowing by government & 2.1 & -2.3 & -1.5 & -2.1 & 1.4 & -0.3 & -1.3 & -3.3 & -1.9 \\
\hline \multirow[t]{2}{*}{ Net claims on private sector } & 1.4 & 3.5 & 2.4 & 5.1 & 2.4 & -0.7 & 2.7 & 3.9 & 5.2 \\
\hline & & \multicolumn{8}{|c|}{ (Changes over 12 months; in percent) } \\
\hline Broad money & 9.4 & 9.0 & 13.8 & 9.1 & 15.9 & 18.0 & 12.5 & 11.8 & 9.5 \\
\hline Net claims on private sector & 2.5 & 6.5 & 0.3 & 9.8 & 5.3 & 5.8 & 3.9 & 8.2 & 10.8 \\
\hline \multicolumn{10}{|l|}{ Memorandum item: } \\
\hline Indicative program exchange rate & $\ldots$ & $\ldots$ & 63.98 & 63.98 & 63.98 & 60.07 & 60.07 & 60.07 & 60.07 \\
\hline
\end{tabular}

Sources: State Bank of Pakistan; and Fund staff estimates.

1/ At indicative program exchange tate.

2/ Stocks as reported in EBS/02/43.

$3 /$ Revised projection based on: (a) program flows set during the second review for variables subject to performance criteria; and (b) revised assumptions. 
Table 6. Pakistan: Accounts of the State Bank of Pakistan, 1999/2000-2002/03

\begin{tabular}{|c|c|c|c|c|c|c|c|c|c|}
\hline & & & \multicolumn{3}{|c|}{ Monetary Program 2001/02 1/ } & \multicolumn{4}{|c|}{ Monetary Program 2002/03 1/ } \\
\hline & \multirow{2}{*}{\multicolumn{2}{|c|}{ Act. }} & \multirow{3}{*}{$\begin{array}{l}\text { Mar. } \\
\text { Act. } \\
2002\end{array}$} & & \multirow{3}{*}{$\begin{array}{r}\text { Act. } \\
2002\end{array}$} & \multirow{3}{*}{$\begin{array}{l}\text { Sep. 3f } \\
\text { Prog. } \\
2002\end{array}$} & \multirow{3}{*}{$\begin{array}{l}\text { Dec. 3/ } \\
\text { Prog. } \\
2002\end{array}$} & \multirow{3}{*}{$\begin{array}{c}\text { Mar. } \\
\text { Prog. } \\
2003\end{array}$} & \multirow{3}{*}{$\begin{array}{l}\text { Jun. } \\
\text { Proj. } \\
2003\end{array}$} \\
\hline & & & & Prog. 2i & & & & & \\
\hline & $1999 / 2000$ & $2000 / 01$ & & 2002 & & & & & \\
\hline & \multicolumn{9}{|c|}{ (End-of-period stocks; in billions of Pakistani rupes) } \\
\hline Net foreign assets & -55.6 & -19.1 & 92.2 & 30.2 & 148.9 & 178.5 & 184.7 & 188.1 & 192.4 \\
\hline Net domestic assets & 553.4 & 552.3 & 476.1 & 556.2 & 436.2 & 421.8 & 431.7 & 430.9 & 445.0 \\
\hline \multicolumn{9}{|l|}{ Of which: } & 217.1 \\
\hline Budgetary support & 392.7 & 361.1 & 289.6 & 378.3 & 249.2 & 224.0 & 232.2 & 228.0 & 238.8 \\
\hline Claims on nongovemment & 51.2 & 40.1 & 24.2 & 27.8 & 22.7 & 22.7 & 22.7 & 22.7 & 22.7 \\
\hline Claims on scheduled banks & 193.4 & 198.0 & 195.6 & 204.0 & 198.9 & 201.4 & 191.9 & 194.4 & 196.9 \\
\hline Privatization account & -2.9 & -2.9 & -2.9 & -2.9 & -2.9 & -2.9 & -2.9 & -2.9 & -2.9 \\
\hline Other items, net & -57.3 & -18.4 & -5.1 & -24.9 & -8.7 & -0.8 & 11.2 & 11.2 & 11.2 \\
\hline $\begin{array}{l}\text { Reserve money } 4 / \\
\text { Of which: }\end{array}$ & 497.8 & 533.2 & 568.3 & 586.5 & 585.1 & 600.3 & 616.3 & 619.0 & 637.4 \\
\hline Banks" reserves & 114.7 & 127.3 & 101.5 & 139.9 & 112.2 & 119.0 & 115.1 & 116.5 & 120.8 \\
\hline \multirow[t]{2}{*}{ Currency } & 375.1 & 394.6 & 455.6 & 435.4 & 460.2 & 468.7 & 488.6 & 489.9 & 504.1 \\
\hline & \multicolumn{9}{|c|}{ (Changes in percent of stock of reserve money at the beginning of the fiscal year) } \\
\hline Net foreign assets & -3.3 & 7.3 & 20.9 & 9.3 & 31.5 & 6.7 & 7.7 & 8.3 & 9.1 \\
\hline Net domestio assets & 28.4 & -0.2 & -14.3 & 0.7 & -21.8 & -3.8 & -2.1 & -2.3 & 0.2 \\
\hline \multicolumn{10}{|l|}{ Of which: } \\
\hline \multirow[t]{2}{*}{ Budgetary support } & 28.4 & -6.3 & -13.4 & -0.9 & -20.5 & -4.2 & -3.0 & -3.5 & -1.5 \\
\hline & \multicolumn{9}{|c|}{ (Changes over 12 months; in percent) } \\
\hline Reserve money 5/ & 25.1 & 3.3 & 5.7 & 10,0 & 9.7 & 12.9 & 4.5 & 8.9 & 9.2 \\
\hline Currency & 22.4 & 5.2 & 12.5 & 10.3 & 16.6 & 17.4 & 8.1 & 7.5 & 9.0 \\
\hline Memotandum item: & & & & & & & & & \\
\hline Indioative program exchange rate & $\ldots$ & $\cdots$ & 63.98 & 63.98 & 63.98 & 60.07 & 60.07 & 60.07 & 60.07 \\
\hline
\end{tabular}

Source: State Bank of Pakistan; and Fund staff estimates.

$1 /$ At indicative program exchange rates.

2/ Stocks as reported in EBS/02/43.

3/ Revised projection based on: (a) program flows set during the second review for variables subject to performance criteria; and (b) revised assurnptions.

4/ Starting in April 2000/01, reserve money includes special reserves on foreign currency deposits.

5 / For the purpose of calculating the 12 -month growth rate, reserve money is considered net of the special reserves and corrected for the transfornation of the special deposits accounts into treasury bills in December 2000 and March 2001. 
Table 7. Pakistan: Gross Financing Requirements, 2001/02-2003/04

(In millions of U.S. dollars)

\begin{tabular}{|c|c|c|c|c|}
\hline & $\begin{array}{r}\text { Prog. } \\
2001 / 02\end{array}$ & $\begin{array}{r}\text { Est. } \\
2001 / 02\end{array}$ & $\begin{array}{r}\text { Rev. Prog. } \\
2002 / 03\end{array}$ & $\begin{array}{r}\text { Proj. } \\
2003 / 04\end{array}$ \\
\hline Gross financing requirements & $-7,234$ & $-8,006$ & $-5,484$ & $-5,295$ \\
\hline External current account balance & 127 & 1,500 & 164 & -35 \\
\hline Debt amortization & $-5,882$ & $-6,234$ & $-3,959$ & $-4,052$ \\
\hline Medium- and long-term debt & $-2,966$ & $-2,667$ & $-2,751$ & $-2,482$ \\
\hline Public sector & $-2,080$ & $-2,255$ & $-2,283$ & $-2,082$ \\
\hline Multilateral (excluding IMF) & -605 & -604 & -612 & -673 \\
\hline Bilateral & -900 & -817 & -658 & -581 \\
\hline Bonds (net) & -2 & -35 & -192 & -183 \\
\hline Other (including SBP liabilities) & -573 & -799 & -821 & -645 \\
\hline Private sector & -886 & -412 & -468 & -400 \\
\hline Short-term debt & $-2,916$ & $-3,567$ & $-1,208$ & $-1,570$ \\
\hline Public sector & $-1,402$ & $-2,187$ & -951 & $-1,518$ \\
\hline Private sector & $-1,514$ & $-1,380$ & -257 & -52 \\
\hline Repayment of arrears & 0 & 0 & 0 & 0 \\
\hline Gross reserves accumulation & $-1,284$ & $-3,079$ & $-1,365$ & -819 \\
\hline Of which: official reserves & $-1,048$ & $-2,716$ & $-1,002$ & -519 \\
\hline IMF repurchases and repayments & -195 & -194 & -324 & -389 \\
\hline Available financing & 7,234 & 8,006 & 5,484 & 5,295 \\
\hline FDI and portfolio investment (net, excluding public securities) $\mathbf{l}$ & 303 & 476 & 635 & 875 \\
\hline Debt financing from private creditors & 3,051 & 2,968 & 1,630 & 1,250 \\
\hline Medium- and long-term financing & 782 & 487 & 175 & 188 \\
\hline To private sector & 401 & 185 & 175 & 188 \\
\hline To public sector & 381 & 302 & 0 & 0 \\
\hline Short-term financing & 2,269 & 2,481 & 1,455 & 1,062 \\
\hline To public sector & 977 & 1,379 & 1,300 & 900 \\
\hline To private sector & 1,292 & 1,102 & 155 & 162 \\
\hline Official creditors & 2,940 & 2,735 & 2,673 & 2,628 \\
\hline Project lending & 738 & 643 & 744 & 697 \\
\hline Balance of payments support & 2,202 & 2,092 & 1,930 & 1,931 \\
\hline AsDB and World Bank & 951 & 883 & 1,005 & 1,000 \\
\hline Debt relief from bilateral creditors $2 /$ & 1,251 & 1,210 & 925 & 931 \\
\hline Private sector involvement & 0 & 0 & 100 & 100 \\
\hline IMF & 488 & 484 & 446 & 442 \\
\hline Other net capital flows $3 /$ & 453 & 1,344 & 0 & 0 \\
\hline Financing gap & 0 & 0 & 0 & 0 \\
\hline
\end{tabular}

Sources: Ministry of Finance; State Bank of Pakistan; and Fund staff estimates.

1/ Includes privatization receipts.

2/ Debt relief agreed in January 2001 and in December 2001

3/ Includes SBP purchases in the free market. 
Table 8. Pakistan: Summary of Public External Debt and Debt Service, 1998/99-2003/04

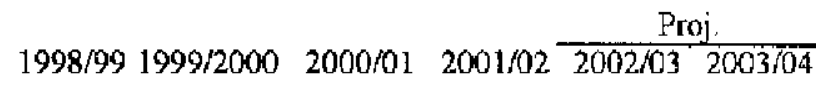

Total public- and publicly-guaranteed external debt

Medium- and long-term debt

Project \& nonproject aid

Commercial banks and IDB

Other (inclucing securities and frozen foreign currency accounts)

Short-temn debt (by initial Inaturity)

Commercial banks and IDB

FEBCs and DBCs

SBP liabilities (including swaps)

Fund credit and loans

Service of medium- and long-term public- and publicly-guaranteed debt Amortization

Interest

Interest on public- and publicly-guaranteed shert-term debt

Total public- and publicly-guaranteed external debt

Long-term

Of which: project and nonproject aid

Short-term

Fund credit and loans

Service of medium- and long-term public- and publicly-guaranteed debt Amortization

Interest

Interest on public- and publicly-guaranteed short-term deb:

Total public- and publicly-guaranteed external debt

Service of medium- and long-term public- and publicly-guaranteed debt Amortization

Interest

Memorandum items:

Implicit interest on public- and publicly-guaranteed external debt

Public external debt service in percent of government revenue (incl. grants)

Total external debt (in millions of U.S. dollars) (In percent of GDP)
(In millions of U.S. dollars)

\begin{tabular}{|c|c|c|c|c|c|}
\hline 29,318 & 29,757 & 32,743 & 33,167 & 33,395 & 32,657 \\
\hline 25,445 & 26,009 & 28,165 & 29,433 & 29,550 & 29,638 \\
\hline 24,105 & 24,792 & 26,647 & 28,199 & 28,566 & 28,770 \\
\hline 730 & 560 & 634 & 383 & 325 & 392 \\
\hline 610 & 657 & 885 & 851 & 659 & 476 \\
\hline 2,049 & 2,253 & 3,075 & 1,795 & 1,784 & 906 \\
\hline 583 & 671 & 834 & 212 & 329 & 229 \\
\hline 196 & 147 & 72 & 53 & 35 & 17 \\
\hline 1,270 & 1,435 & 2,169 & 1,530 & 1,420 & 660 \\
\hline 1,825 & 1,496 & 1,503 & 1,939 & 2,061 & 2,114 \\
\hline 3,499 & 4,175 & 2,616 & 3,548 & 3,771 & 3,685 \\
\hline 2,484 & 3,113 & 1,540 & 2,449 & 2,607 & 2,470 \\
\hline 1,015 & 1,062 & 1,076 & 1,100 & 1,164 & 1,214 \\
\hline 265 & 319 & 284 & 198 & 138 & 126 \\
\hline \multicolumn{6}{|c|}{ (In percent of GDP) } \\
\hline 51.5 & 54.6 & 55.8 & 54.5 & 50.5 & 45.5 \\
\hline 44.7 & 47.8 & 48.0 & 48.4 & 44.7 & 41.3 \\
\hline 42.4 & 45.5 & 45.4 & 46.4 & 43.2 & 40.1 \\
\hline 3.6 & 4.1 & 5.2 & 3.0 & 2.7 & 1.3 \\
\hline 3.2 & 2.7 & 2.6 & 3.2 & 3.1 & 29 \\
\hline 6.1 & 7.7 & 4.5 & 5.8 & 5.7 & 5,1 \\
\hline 4.4 & 5.7 & 2.6 & 4.0 & 3.9 & 3.4 \\
\hline 1.8 & 1.9 & 1.8 & 1.8 & 1.8 & 1.7 \\
\hline 0.5 & 0.6 & 0.5 & 0.3 & 0.2 & 0.2 \\
\hline
\end{tabular}

(In percent of exports of goods and nonfactor services)

\begin{tabular}{rrrrrr}
331.6 & 310.7 & 318.4 & 300.2 & 286.6 & 268.1 \\
39.6 & 43.6 & 25.4 & 32.1 & 32.4 & 30.2 \\
28.1 & 32.5 & 15.0 & 22.2 & 22.4 & 20.3 \\
11.5 & 11.1 & 10.5 & 10.0 & 10.0 & 10.0 \\
& & & & & \\
4.4 & 4.7 & 4.4 & 3.9 & 3.9 & 4.1 \\
37.0 & 44.2 & 25.7 & 31.0 & 30.6 & 27.8 \\
34,062 & 34,063 & 36,156 & 36,007 & 35,745 & 34,871 \\
59.9 & 62.5 & 61.7 & 59.2 & 54.1 & 48.6 \\
\hline
\end{tabular}

Sources: State Bank of Pakistan; Ministry of Finance; and Fund staff estimates. 
Table 9. Pakistan: Indicators of External Vulnerability, 1998/99-2002/03

1998/99 1999/2000 2000/01 2001/02 $\begin{array}{rrr}\text { Latest available } & \text { Proj. } \\ \text { observation } & 2002 / 03\end{array}$

Financial indicators

Net public debt (in percent of GDP)

Broad money (12-month percentage change)

Private sector credit (12-month percentage change)

180-day treasury bill yield (in percent)

180-day treasury bill yield, real (in percent)

Karachi Stock Exchange index

End-of-period

Period average

Extenal Indicators

Exports (year-on-year percentage change, in U.S. dollars)

Imports (year-on-year percentage change, in U.S. dollars)

Terms of trade (12-month percentage changes)

Current account balance (excluding official transfers in percent of GDP)

Gross Official Reserves (in millions of U.S. dollars)

In weeks of imports of goods and nonfactor services

In percent of broad money

In percent of total shart-term debt at remaining maturity

Total external debt (in millions of U.S. dollars)

In percent of exports of goods and nonfactor services

Actual debt service (in percent of exports of goods and services) $1 /$

Exchange rate (Pakistani rupees per U.S. dollar, period average)

Real exchange rate (12-month percentage change)

$\begin{array}{rrrrrrr}93.6 & 91.6 & 100.9 & 95.5 & \ldots & \ldots \\ 5.2 & 9.4 & 9.0 & 15.2 & 15.22 / & 9.5 \\ 8.5 & 2.5 & 6.4 & 5.3 & 5.32 / & 10.8 \\ 12.9 & 8.8 & 10.4 & 8.1 & 6.43 / & \ldots \\ 7.4 & 5.1 & 6.0 & 5.4 & 2.73 / & \ldots \\ & & & & & \\ 1,055 & 1,521 & 1,366 & 1,770 & 1,9554 / & \ldots \\ 985 & 1,514 & 1,436 & 1,514 & \ldots & \ldots\end{array}$

\begin{tabular}{|c|c|c|c|c|c|}
\hline-10.7 & 8.8 & 9.1 & 2.2 & $5.35 /$ & 8.0 \\
\hline-5.7 & -0.1 & 6.2 & -6.9 & $7.85 /$ & 10.1 \\
\hline 4.1 & -9.2 & -1.6 & -0.9 & $\cdots$ & 0.9 \\
\hline-4.7 & -3.9 & -3.3 & 0.1 & . & -1.1 \\
\hline 1,680 & 908 & 1,679 & 4,329 & $5,4334 /$ & 5,292 \\
\hline 7.4 & 3.8 & 7.5 & 17.5 & $\cdots$ & 20.0 \\
\hline 6.6 & 3.3 & 7.0 & 14.8 & $\cdots$ & 16.5 \\
\hline 22.1 & 10.9 & 23.7 & 71.7 & $\ldots$ & 103.4 \\
\hline 34,062 & 34,063 & 36,156 & 36,007 & $\cdots$ & 35,745 \\
\hline 385.2 & 355.7 & 351.6 & 325.9 & 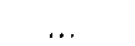 & 306.8 \\
\hline 76.7 & 80.1 & 60.4 & 61.0 & $\cdots$ & 41.6 \\
\hline 50.1 & 51.6 & 58.3 & 61.3 & 59.34 & \\
\hline-9.1 & -0.6 & -2.6 & -1.2 & $2.42 J$ & \\
\hline
\end{tabular}

Sources: Pakistani authorities; Bank for International Settlements; and Fund staff estimates.

1/ Scheduled debt service on total debt minus rescheduled debt service plus debt service on previously rescheduled debt; includes all short-term debt.

2/ June 2002.

$3 /$ August 2002.

4/ September 12, 2002.

5/ Second quarter of calendar year 2002. 
Table 10. Pakistan: Indicators of Fund Credit, 2000/01-2007/08 1/

Proj.

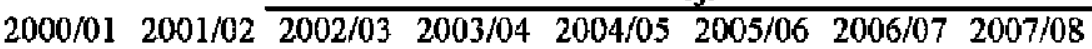

\begin{tabular}{|c|c|c|c|c|c|c|c|c|}
\hline \multicolumn{9}{|l|}{ Outstanding Fund credit } \\
\hline In millions of SDRs & 1,207 & 1,524 & 1,611 & 1,648 & 1,524 & 1,207 & 1,091 & 971 \\
\hline \multicolumn{9}{|l|}{ In percent of: } \\
\hline Quota & 116.7 & 147.5 & 155.9 & 159.4 & 147.4 & 116.7 & 105.5 & 93.9 \\
\hline GDP & 2.6 & 3.2 & 3.1 & 2.9 & 2.5 & 1.9 & 1.6 & 1.4 \\
\hline Exports of goods and nonfactor services & 14.6 & 17.6 & 17.7 & 17.4 & 15.0 & 11.2 & 9.5 & 8.0 \\
\hline Public- and publicly-guaranteed debt & 4.6 & 5.8 & 6.2 & 6.5 & 6.1 & 4.9 & 4.5 & 3.9 \\
\hline \multicolumn{9}{|l|}{ Debt service to the Fund } \\
\hline In millions of SDRs & 228 & 194 & 290 & 351 & 331 & 222 & 126 & 129 \\
\hline In millions of U.S. dolfars & 294 & 247 & 371 & 451 & 425 & 285 & 162 & 166 \\
\hline \multicolumn{9}{|l|}{ In percent of: } \\
\hline Exports of goods and nonfactor services & 2.9 & 2.2 & 3.2 & 3.7 & 3.3 & 2.1 & 1.1 & 1.1 \\
\hline Gross official reserves & 17.5 & 5.7 & 7.0 & 7.9 & 6.7 & 4.1 & 2.1 & 2.0 \\
\hline
\end{tabular}

Sources: IMF Treasurer's Department and Fund staff estimates.

1/ Assuming PRGF disbursements as scheduled. 
Table 11. Pakistan: Social Indicators, 1970-2004

\begin{tabular}{|c|c|c|c|c|c|c|c|}
\hline \multirow[b]{2}{*}{ Population } & \multicolumn{4}{|c|}{$\frac{\text { Latest single year }}{1980-85}$} & \multirow[t]{2}{*}{$\begin{array}{l}\text { I-PRSP } \\
\text { Target } \\
2003 / 04\end{array}$} & \multicolumn{2}{|c|}{$\begin{array}{l}\text { Lower-income } \\
\text { South Asia (world-wide) } \\
\text { Latest single year }\end{array}$} \\
\hline & & \multirow{6}{*}{$\begin{array}{r}94.8 \\
2.7 \\
29.8 \\
6.5 \\
3.7\end{array}$} & \multirow{6}{*}{$\begin{array}{r}136.7 \\
2.4 \\
44.8 \\
4.8 \\
5.9\end{array}$} & \multirow{6}{*}{$\begin{array}{r}142.9 \\
2.2 \\
47.5 \\
4.7 \\
7.8\end{array}$} & & \multirow{2}{*}{\multicolumn{2}{|c|}{$2,459.0$}} \\
\hline Total population, mid-year (in millions) & 71.0 & & & & \multirow{3}{*}{$\ldots$} & & \\
\hline Growth rate (percent annual average) & 3.2 & & & & & 1.9 & 1.9 \\
\hline Urban population (percent of population) & 26.4 & & & & & 28.0 & 32.0 \\
\hline Total fertility rate (births per woman) & 7.0 & & & & 4.1 & 3.4 & 3.7 \\
\hline Unemployment (as percentage of total labor force) & $\ldots$ & & & & $\ldots$ & $\ldots$ & $\cdots$ \\
\hline \multicolumn{8}{|l|}{ Income } \\
\hline GNI per capita (U.S. dollars) $1 /$ & 150.0 & 330.0 & 450.0 & 440.0 & & 440.0 & 410.0 \\
\hline Consumer price index (percentage change) & 20.9 & 5.6 & 4.1 & 3.2 & 5.0 & 4.1 & 4.1 \\
\hline Food price index (percentage change) & $\ldots$ & 4.4 & 3.9 & 2.0 & 5.0 & $\ldots$ & $\ldots$ \\
\hline \multicolumn{8}{|l|}{ Social indicators } \\
\hline \multicolumn{8}{|l|}{ Public expenditure } \\
\hline Health (percent of GDP) & & & 0.5 & 0.5 & 0.5 & 0.9 & 1.2 \\
\hline Education (percent of GNP) & 2.2 & 2.9 & 1.6 & 1.8 & 1.8 & 3.1 & 3.3 \\
\hline \multicolumn{8}{|l|}{ Education $2 /$} \\
\hline Total & 39.5 & 43.7 & 73.5 & $\ldots$ & 100.0 & 100.3 & 95.0 \\
\hline Male & 52.7 & 55.7 & 100.6 & $\ldots$ & 119.0 & 109.6 & 102.5 \\
\hline Fenale & 25.5 & 30.4 & 45.4 & $\ldots$ & 76.0 & 90.2 & 85.5 \\
\hline $\begin{array}{l}\text { Gross secondary school enrollment rate } \\
\text { (in percent of age group) }\end{array}$ & 14.7 & 17.2 & 25.6 & $\ldots$ & 68.0 & 48.6 & 45.7 \\
\hline Iliteracy rate (as percentage of population aged 15 and above & 75.8 & 68.2 & 55.0 & 54.0 & 41.0 & 45.0 & 38.0 \\
\hline \multicolumn{8}{|l|}{ Access to safe water (in percent of population) } \\
\hline Total & & 38.0 & 63.0 & $\ldots$ & 68,0 & 87.0 & 76.0 \\
\hline Urban & 75.0 & 84.0 & 83.0 & $\ldots$ & 87.0 & 92.0 & 88.0 \\
\hline Rural & 5.0 & 28.0 & 53.0 & $\ldots$ & 57.0 & 85.0 & 70.0 \\
\hline \multicolumn{8}{|l|}{ Inmutuization rate (percent of children under 12 months) } \\
\hline Measles & $\ldots$ & 23.0 & 81.0 & $\ldots$ & $\cdots$ & 62.7 & 64.0 \\
\hline DPT & $\cdots$ & 30.0 & 80.0 & $\ldots$ & $\ldots$ & 75.2 & 70.4 \\
\hline \multicolumn{8}{|l|}{ Life Expectancy at birth (years) } \\
\hline Total & 52.3 & 57.4 & 62.5 & 63.0 & 64.4 & 52.6 & 59.1 \\
\hline Male & 52.1 & 56.9 & 61.5 & $\ldots$ & $\ldots$ & 61.8 & 58.1 \\
\hline Female & 52.5 & 58.0 & 63.6 & $\ldots$ & $\ldots$ & 63.4 & 60.2 \\
\hline \multicolumn{8}{|l|}{ Mortality } \\
\hline Children under 5 years (per thousand live bitths) & 183.0 & 161.0 & 126.0 & 110.3 & 65.0 & 98.6 & 116.3 \\
\hline Adult ( $15 m 59$ years) & & & & & & & \\
\hline Male (per 1,000 population) & 339.5 & 282.5 & 186.0 & $\ldots$ & $\ldots$ & 223.2 & 288.3 \\
\hline Female (per 1,000 population) & 381.1 & 290.9 & 153.0 & $\ldots$ & $\ldots$ & 212.2 & 257.7 \\
\hline
\end{tabular}

Source: World Bank: World Development Indicators; and Government of Pakistan.

1/ Gross national income divided by midyear population. The impact of exchange rate fluctuations in the cross-country comparison of national income is reduced notably by using three-year averages for exchange rates (World Bank's Atlas conversion factar).

2/ Education targets in the I-PRSP are not comparable with historical data for the previous years. The outstanding methodological and source issues related to the selection of education baseline indicators and output targets will be addressed during the preparation of the full PRSP. 


\section{Pakistan: Fund Relations \\ As of August 31, 2002}

I. Membership Status: Joined: 07/11/1950; Article VIII

II. General Resources Account:

Quota

Fund Holdings of Currency

Reserve position in Fund

III SDR Department:

Net cumulative allocation

Holdings

IV. Outstanding Purchases and Loans:

Stand-by arrangements

Extended arrangements

Contingency and Compensatory

ESAF/PRGF arrangements $\underline{\text { SDR Million }}$

$1,033.70$

$1,915.15$

0.12

SDR Million

169.99

8.93

SDR Million

465.00

152.04

264.52

599.80
\%Quota

100.00

185.27

0.01

\%Allocation

100.00

5.25

\%Quota

44.98

14.70

25.59

58.02

V. Latest Financial Arrangements:

\begin{tabular}{|c|c|c|c|c|}
\hline Type & Approval & $\begin{array}{c}\text { Expiration } \\
\text { Date }\end{array}$ & $\begin{array}{c}\text { Approved } \\
\text { Amount } \\
\text { (SDR Million) }\end{array}$ & $\begin{array}{l}\text { Amount Drawn } \\
\text { (SDR Million) }\end{array}$ \\
\hline PRGF & $12 / 06 / 2001$ & $12 / 05 / 2004$ & $1,033.70$ & 258.44 \\
\hline Stand-By & $11 / 29 / 2000$ & $09 / 30 / 2001$ & 465.00 & 465.00 \\
\hline $\mathrm{EFF}$ & $10 / 20 / 1997$ & $10 / 19 / 2000$ & 454,92 & 113.74 \\
\hline
\end{tabular}

VI. Projected Obligations to Fund Under the Repurchase Obligations Assumptions (SDR Million; based on existing use of resources and present holdings of SDRs)

\begin{tabular}{|c|c|c|c|c|c|c|}
\hline & \multirow{2}{*}{$\begin{array}{l}\text { Overdue } \\
08 / 31 / 02 \\
\end{array}$} & \multirow[b]{2}{*}{2002} & \multicolumn{4}{|c|}{ Forthcoming } \\
\hline & & & 2003 & 2004 & 2005 & 2006 \\
\hline Principal & 0.0 & 73.1 & 292.8 & 330.5 & 291.4 & 124.5 \\
\hline Charges/Interest & 0.0 & 8.9 & 28.3 & 21.2 & 13.7 & 7.6 \\
\hline Total & 0.0 & 82.0 & 321.1 & 351.7 & 305.1 & 132.2 \\
\hline
\end{tabular}

Repurchase Obligations: Repurchases in the credit tranches including the Compensatory Financing Facility, are to be completed in $31 / 4-5$ years. Repurchases under the Extended Fund Facility are due in $4 \frac{1}{2}-10$ years. 


\section{A. Nonfinancial Relations}

\section{Exchange System}

Prior to mid-1998, Pakistan implemented a fixed exchange rate system with periodic step devaluation to compensate for the inflation differential with major trading partners. On July 21, 1998, a dual exchange system was introduced consisting of a fixed official exchange rate at PRs 46 per US\$1 and a floating interbank market exchange rate (FIBR). Under this system, all authorized transactions were effectively conducted at the so-called "composite rate" which was the weighted average of the FIBR and the official exchange rate. In addition, since May 28, 1998, withdrawais from foreign currency accounts have only been allowed in Pakistani rupees (at the official exchange rate). An advance import deposit of 30 percent was introduced on July I2, 1998; it was subsequently reduced to 20 percent on January 9, 1999 and to 10 percent on January 24, 1999, and was eliminated on February 24, 1999. On May 19, 1999, the official exchange rate was eliminated and the exchange rate system unified, with all international transactions conducted at the FIBR. As of September 10, 2002, the FIBR was PRs 59.27 per US\$1. Pakistan's exchange regime is classified as managed floating with no predetermined path for the exchange rate.

\section{Last Article IV Consultation}

The last Article IV consultation discussions were held in Islamabad during September 2000. The staff report (EBS/00/230 and Supplements I and 2), together with Pakistan's request for a Stand-By Arrangement, was discussed by the Executive Board on November 29, 2000. In concluding the 2000 Article IV consultation, the Executive Board adopted Decision No. 12335 $(00 / 117)$ on November 29, 2000.

\section{Safeguards Assessments}

A Stage One safeguards assessment of the State Bank of Pakistan (SBP) was completed on October 26, 2000. The assessment concluded that high risks may exist in the area of external audit mechanism, financial reporting, and internal control, and recommended a Stage Two (on-site) assessment. The Stage Two (on-site) assessment was completed on February 13, 2001 and staff's findings and recommendations were reported to Fund management (EBS/01/39, Appendix IV) and to the authorities. A monitoring exercise related to safeguards developments at the SBP has been undertaken. All the recommended remedial actions arising from the initial safeguards assessment have been implemented and no new critical vulnerabilities have been identified. The Stage Two recommendations included in the Stand-By Arrangement conditionality remain applicable to Pakistan's PRGF arrangement, which was approved on December 6, 2001 and is scheduled to expire on December 5, 2004.

\section{ROSCs}

\begin{tabular}{|l|r|r|}
\hline Fiscal Transparency Module & $11 / 28 / 2000$ & SM/00/264 \\
\hline
\end{tabular}




\section{Recent Technical Assistance}

a. FAD: In May/June 1997, a mission conducted a review of the public expenditure management system. In May 1997, May 1998, and again in February 1999, missions reviewed the operation of the GST, and recommended measures to improve tax administration and increase tax compliance. In April 1999, a mission reviewed the income tax system and developed a strategy to improve its efficiency, potential for long-term development and ease of administration. A mission in January-February 2000 assisted with the revision of fiscal data and advised on measures to strengthen the fiscal reporting and accounting systems. In May 2000, a mission assisted with the preparation of the fiscal module of the Report on the Observance of Standards and Codes (ROSC). In August 2000, a joint FAD-STA mission reviewed progress in the strengthening of the fiscal reporting and accounting systems and assisted authorities in the preparation of revised fiscal data for 1993/94-1998/99. In September 2000, a mission provided technical assistance on overhauling the income tax law. In January 2001, a mission provided advice on priorities and strategies for improving the tax collection operations of the Central Board of Revenue (CBR). A follow-up mission on income tax policy took place in May 2001. In August 2001, a mission assisted the authorities in the preparation of tax administration reforms. In January 2002, another mission advised the authorities on fiscal data management, quality, and transparency.

b. MAE: In May/June 1996, a mission provided technical assistance on the transition to indirect monetary control. In June/July 1997, a technical assistance mission assisted in developing a strategy to phase out subsidized forward cover for foreign currency deposits and to improve the institutional structure of the foreign exchange market. In February, May/June, and November 1998, MAE fielded follow-up TA missions on foreign exchange market reform. In May 1999, mission provided TA in the area of integration of open market operations and the foreign exchange market. In July 2000, a joint MAE-MED mission provided technical advice on issues relating to the transformation to a financial system that is compliant with Islamic finance principles. In September 2000 , a mission provided technical assistance on enhancing the market orientation of the foreign exchange market. In February 2001, a mission provided TA on the design of public finance investment that are compatible with Islamic finance principles.

c. STA: In May/June 2000, a mission reviewed the compilation of data considered most important for program design and monitoring. A follow-up mission in July helped develop a series of time-bound measures to improve the national accounts statistics. In January 2001, an expert from STA provided technical advice and training to the Federal Bureau of Statistics for a three-stage development of producer price indices. In February 2002, a mission reviewed external sector statistics and provided advice on steps to be undertaken to subscribe to the SDDS

d. LEG: In May/July 2001 a LEG consultant assisted the authorities in the preparation of the new income tax law, which was promulgated in September 2001.

\section{Resident Representative}

A resident representative has been stationed in Islamabad since August 1991. 


\section{Pakistan: Fund-Bank Relations}

\section{Partnership in Pakistan's development strategy}

1. The government of Pakistan's development strategy is set forth in its Interim Poverty Reduction Strategy Paper (I-PRSP). The I-PRSP focuses on (a) strengthening governance and the integrity of the civil service; (b) creating opportunities through accelerating growth of agriculture, small- and medium-scale industries, information technology, and oil and gas sectors; and (c) reducing poverty through revival of growth and re-orienting public expenditure towards human development and poverty reduction. A Joint Staff Assessment (JSA) on the I-PRSP was discussed by the Boards of the World Bank and the IMF on December 4, and 6, 2001, respectively. The full Poverty Reduction Strategy Paper is expected to be completed after October 2002 when a newly elected government takes office.

2. The MMF is supporting Pakistan's poverty reduction efforts in the context of the threeyear arrangement under the Poverty Reduction and Growth Facility (PRGF). The Fund's program supports the continued pursuit of sound macroeconomic policies, in particular sustained fiscal adjustment, while increasing the share of poverty reduction-related public spending; strengthening governance; tax policy and administration reform; public enterprise restructuring and privatization; and financial sector and foreign exchange market reforms. The Fund takes the lead in the policy dialogue on macroeconomic policies including overall fiscal and monetary policy. In addition to macroeconomic targets, the Fund has established structural performance criteria relating to reforms in the areas of tax policy and administration, power sector reform, foreign exchange market liberalization, and public expenditure management. As outlined more fully below, the World Bank has complemented the Fund's work through support to structural reforms in the social sectors and support of the growth agenda through deregulation of key sectors such as power, oil and gas, and banking reforms whose performance have a strong bearing on growth and public finances.

\section{World Bank Group strategy}

3. The objective of the World Bank Group's assistance strategy is to help Pakistan reduce poverty through support of the government's implementation of its Interim Poverty Reduction Strategy. The World Bank Group's program priorities are focused on the reforms to (a) strengthen macroeconomic stability and government effectiveness; (b) improve the business environment for growth; and (c) improve equity through support for pro-poor and pro-gender equity policies. The 2002 Country Assistance Strategy, which was presented to the World Bank's Board of Executive Directors on June 11, 2002, sets out a strategy in support of these objectives for the period FY 03-05. ${ }^{1}$

\footnotetext{
' http://www.worldbank.org/pakistancas
} 
4. The World Bank works closely with the IMF and the government on structural reforms underpinning macroeconomic stability, particularly in areas with an impact on the balance of payments and public finances. In this context, the recently approved DA-financed US $\$ 500$ million Structural Adjustment Credit supports the government's actions in the areas of improving public expenditure management and supporting reforms of tax administration, safe and sound banking, efficient public utilities, and structural fiscal and governance reforms. The World Bank has also approved structural adjustment credits for two provinces (Sindh and NorthWest Frontier Province (NWFP)) totaling US\$190 million supporting provincial reform strategies to improve resource management and strengthen provision of public services by local governments and communities.

5. The World Bank Group's support to strengthening the investment climate includes a combination of analytical work and financial assistance targeted to reforms in key sectors. The World Bank Group continues to encourage the federal and provincial governments to further pursue the ongoing liberalization and modernization of trade, industrial, business, and labor regulations. To build the knowledge base to underpin the policy dialogue on private sector development, the World Bank Group plans to carry out a significant program of analytical work. In addition to a Development Policy Review (completed in FY 02), the World Bank will complete in FY 03 an Investment Climate and Economic Performance Study. In addition to the governance reforms which have a direct bearing on the investment climate, the World Bank Group continues to support financially and through policy advice the reforms of the governance and regulatory environment for power, gas, oil, financial sector, pricing and tariffs reforms, and privatization.

6. In the social sectors, the World Bank Group's assistance is geared toward support to the implementation of the Education Sector Reform (ESR) Strategy and the government's priority of strengthening public health programs and maternal and child health and family planning. Accordingly the World Bank is focusing on (a) programmatic support to the National Education Sector Reform Strategy; (b) support to the National Education Assessment System; (c) a program of analytical work to underpin the policy dialogue during the implementation of the ESR; and (d) province-based support to implementing the ESR within the fiscal and economic reforms of Sindh and NWFP to start with. Prior actions related to the recently approved Structural Adjustment Credit included an increase in budget allocations for human development and pro-poor expenditures. In FY 03 World Bank Group assistance to health sector reforms will also include the HIV/AIDS Prevention Project, as well as analytical work, technical assistance, and policy dialogue, as appropriate.

7. Supporting the rural sector through community-based infrastructure projects (particularly for water supply and sanitation services) and the spread of micro-credit have been part of the World Bank Group's strategy to reduce and mitigate risks for Pakistan's poor. The World Bank will continue to pilot new approaches, and also help scale up those which have proven effective such as the Community Infrastructure and Services Project (CIP) and the Pakistan Poverty Alleviation Fund (PPAF). 
8. IBRD and IDA have approved 84 loans and 116 credits to Pakistan since 1952, totaling US\$6,975.3 million and US\$7,109.2 million, respectively. Of these amounts, US $\$ 3,397.3$ million has been repaid and US\$681.2 million remain undisbursed. Current total obligations to the World Bank stand at US\$8,110.9 million, of which US\$5,307.8 million are IDA and US $\$ 2,803.2$ million are IBRD, as of 31 July, 2002. IDA credits constitute 65 percent and IBRD loans 35 percent of the World Bank portfolio. (See table below)

\section{World Bank-Fund collaboration in specific areas}

9. As part if its overall assistance to Pakistan-through lending, country analytic work, and technical assistance-the World Bank supports policy reforms in the following areas in collaboration with the Fund:

10. Financial sector reforms. Pakistan has been engaged in far-reaching reforms of the financial sector for five years. Significant progress has been made, particularly with respect to reform of the banking sector. Regulations have been strengthened, loan recoveries increased, and the quality of management improved. Privatization of the three nationalized commercial banks-the core of the government's reform strategy-is underway. The vision for the sector is for a market-oriented, predominantly private system that operates under a strong regulatory framework supported by an effective banking court system. The World Bank and the Fund have worked closely together to support needed policy reforms. The World Bank has maintained close dialogue with the government on banking sector reform following the Banking Sector Adjustment Loan in December 1997, through technical assistance to the central bank and preparation of a financial sector update in 2000 . World Bank support is also being provided through implementation of two ongoing projects: the Banking Sector Restructuring and Privatization Project and the Banking Sector Technical Assistance Project. A joint World Bank/Fund Financial Sector Assessment is planned for FY 03.

11. Power sector reforms: Losses in the power sector have been an ongoing source of macroeconomic instability in Pakistan, threatening achievement of fiscal deficit targets and preventing reorientation of public expenditure toward poverty reduction programs. In the context of the structural adjustment operations approved in FY 01 and FY 02, the World Bank has taken the lead in working with the Government of Pakistan to unbundle and privatize the state-owned Water and Power Development Authority (WAPDA). During the transition toward privatization, WAPDA's financial viability is being restored through implementation of a medium-term financial improvement plan developed in consultation with the World Bank. The plan aims to sharply reduce the level of budget support to WAPDA through a combination of tariff increases and other measures. Adoption of specific measures, including tariff increases, needed to achieve an overall debt service coverage ratio of 1.2 by the end of $2002 / 03$ was among the prior actions in connection with the second Structural Adjustment Credit. Given the importance of this initiative to ensuring achievement of Pakistan's macroeconomic targets, progress in implementing the financial improvement plan is being monitored closely by both the World Bank and Fund. 
12. Public expenditure management. The quality of Pakistan's public expenditures has long been compromised by poor financial management practices. The government has made one of its top priorities to accelerate reforms towards achieving a modern public accounting and integrated financial management system at the federal, provincial, and district level. The World Bank, the IMF, and the government have been working closely in this area for more than two years. Under a policy framework agreed with the government and the Fund, the World Bank is taking the lead in supporting implementation of the reform program while the IMF is providing related technical assistance. World Bank support is being provided in the context of the ongoing Pakistan Improvement of Financial Reporting and Accounting (PIFRA) project through which the national accounting and audit systems are being modernized. A follow-up on PIFRA II project will further these efforts, to improve the accuracy, completeness, reliability, and timeliness of intra-year and year-end government financial reports in Pakistan at the national, provincial, and district levels. Analytical and diagnostic support is being provided in the form of a Country Financial Accountability Assessment (CFAA) planned to be completed in FY 03. Policy measures relating to financial management have been included as prior actions for World Bank structural adjustment lending at both the national and provincial level

13. Tax policy and administration reforms. The failure to improve tax administration has probably been Pakistan's most severe weakness in economic management. The Fund has taken the lead in supporting tax policy reforms, providing technical assistance leading, inter alia, to the formulation of an income tax reform package which became effective July 1, 2002. In consultation with the Fund and the World Bank, Pakistan has also launched a program for the fundamental restructuring of the Central Board of Revenues (CBR) in order to improve the efficiency of tax administration. The CBR reform effort is being supported by bath the World Bank and the Fund. The Fund has stressed the importance of improved revenue collection performance by CBR as key element in ensuring the sustainability of Pakistan's considerable achievements in fiscal consolidation. The structural performance criteria of the PRGF include adoption of tax policy changes and implementation of CBR reform. Through the Project Preparation Facility, the World Bank is supporting preparation of a Tax Administration Reform Project which is scheduled for approval in FY 04. This support includes financing of consultants to develop a detailed reform strategy for restructuring of $\mathrm{CBR}$ in the areas of human resource management, information technology, business process re-engineering, and tax payer facilitation.

14. Social impact analysis. As part of the preparation of the World Bank structural adjustment lending and the IMF PRGF program, the World Bank and the IMF have agreed to review closely the social impact of reforms in a pilot program of collaboration. Work is being led by the World Bank's Social Development Unit. Two areas of reform will receive close scrutiny during implementation (a) devolution and its impact on the quasity of service delivery, especially to the poor, and (b) tariff and policy reforms in the gas and power sectors. This work is now underway. 


\section{Pakistan: Financial Relations with the World Bank Group Statement of Loans and Credits}

As of July 31,2002

(In millions of U.S. dollars)

\begin{tabular}{lrrr}
\hline & IBRD & IDA & TOTAL \\
\hline Original principal & $6,975.25$ & $7,109.19$ & $14,084.44$ \\
Cancellation & $1,163.49$ & 875.05 & $2,038.54$ \\
Disbursements to date & $5,750.46$ & $5,910.03$ & $11,660.49$ \\
Repayments & $2,784.49$ & 612.83 & $3,397.31$ \\
Undisbursed & 198.75 & 482.42 & 681.17 \\
Exchange adjustment & $(129.29)$ & 0.00 & $(129.29)$ \\
Borrowers Obligation & $2,803.22$ & $5,307.75$ & $8,110.97$ \\
\hline
\end{tabular}




\section{Pakistan: Statistical Issues}

1. The staff believes that data reporting and accounting procedures are adequate for program monitoring purposes. The authorities are responsive to data requests and report to the Fund, on a routine basis, monthly data on extemal trade, prices, federal government expenditures and tax revenues, government bank borrowing, and money with a lag of less than a month. Moreover, the authorities provide daily data through the resident representative's offce on international reserves, exchange rates, and the Karachi Stock Exchange index with a one-day lag.

2. At present, the methodology for the compilation of national accounts extrapolates certain components of GDP using a variety of indicators and data sources that have limited coverage. The estimates for some activities, particularly small-scale manufacturing, dwelling services, and other services continue to be made using constant growth rates estimated from an outdated benchmark. In view of these shortcomings, the authorities have embarked on an action plan to improve national accounts statistics, based on Statistic's Department (STA) recommendations. The Federal Bureau of Statistics (FBS) has undertaken a series of sectoral studies with the purpose of better assessing the sectors contribution to GDP. These studies (23) were completed in the summer of 2002 . The findings of these studies will be used to revise national accounts statistics and establish the new base year to 1999/2000. Data on wages and employment are not reported; and systems for the compilation of quarterly GDP are not yet well developed.

3. The FBS produces three price indices: CPI, WPI, and SPI (sensitive price indicator). The CPI and WPI are compiled on a monthly basis. The CPI has recently been rebased to 2000/01. The SPI is compiled on a weekly basis and consists of 46 essential commodities that are consumed by the lowest income group. Weights for the 51 items are the same as in the CPI. In the context of the action plan to improve National Account statistics, the FBS is currently working on the development of producer price indices (PPIs) in line with recommendations of a technical assistance mission from STA. The establishment of satisfactory PPIs should help improve GDP deflators.

4. Data on government finances have suffered from a lack of information on economic and functional classification of government outlays; and inadequate reporting by provinces on their fiscal operations. Moreover, the quality of fiscal data has been adversely affected by a lack of coordination between the Ministry of Finance and the Accountant General Pakistan Revenue in generating fiscal reports and lack of facility to compile data on commitments or accounts payable. In line with the recommendations of recent Fiscal Affairs Department (FAD) and Statistic's Department (STA) technical assistance missions, measures have been taken to address these issues and further steps are being implemented. The separation of accounting and auditing functions has already been implemented and the authorities have started posting in the internet reconciled public accounts both at the federal and provincial level. In addition, the adoption of a new accounting model and chart of accounts recommended under the PIFRA project should help overcome remaining deficiencies. In the context of the I-PRSP, and in view of its focus on governance and transparency, the 
authorities are committed to improve the accounts reconciliation process, particularly at the local level, and have designed an action plan for regularly tracking and reporting social development expenditure at the federal, provincial and district level.

5. Notwithstanding the good provision of statistics on balance of payments, timely and more accurate reporting on capital flows, including both official assistance and private investment flows, would be desirable.

6. External debt statistics have been compiled for government and governmentguaranteed debt by the Ministry of Finance and on private debt by the State Bank of Pakistan (SBP). The balance of payments difficulties that surfaced about May 1998 revealed significant weaknesses in Pakistan's external debt reporting, as data were not available with required frequency and there was no comprehensive reconciliation of data collected by different departments. In that context, the authorities initiated a complete inventory of all public sector debt liabilities. Most of the public sector debt data were, until recently, in a manual bookkeeping system. In 1996, the authorities began developing, with the assistance of the AsDB, a computerized debt management system, covering official assistance and supplier credits to Pakistan's public sector. The system became fully operational in end-2001.

7. Remedial actions taken by the SBP as a result of the Fund's recent safeguards assessment, have increased the integrity of the central bank's monetary statistics. However, there are still large discrepancies in some monetary statistics compiled by the SBP for program monitoring and those published in IFS, including on net foreign assets. MED staff discussed these issues with the authorities in May, with a view to harmonizing these statistics as much as possible.

8. Following an STA mission in February 2002, the authorities committed to subscribe to the SDDS in 2003 and to the GDDS as soon as possible. As a first step to improve data dissemination, they have published quarterly balance of payments statistics on the SBP's website and issued an Advance Release Calendar for selected economic data. The authorities are also designing a survey on wages and earnings to improve the database on labor market indicators. A data ROSC mission was scheduled to take place this summer but was postponed on security grounds. 
Pakistan: Core Statistical Indicators

(As of September 23, 2002)

\begin{tabular}{|c|c|c|c|c|c|c|c|c|c|c|c|c|}
\hline & $\begin{array}{l}\text { Exchange } \\
\text { Rates }\end{array}$ & $\begin{array}{c}\text { Convertible } \\
\text { Intemational } \\
\text { Reserves }\end{array}$ & $\begin{array}{c}\text { Central } \\
\text { Bank } \\
\text { Balance } \\
\text { Sheet }\end{array}$ & $\begin{array}{c}\text { Reserve' } \\
\text { Base } \\
\text { Money }\end{array}$ & $\begin{array}{l}\text { Broad } \\
\text { Money }\end{array}$ & $\begin{array}{l}\text { Interest } \\
\text { Rates }\end{array}$ & $\begin{array}{l}\text { Consumer } \\
\text { Price } \\
\text { Index }\end{array}$ & $\begin{array}{l}\text { Exportsi } \\
\text { Imports }\end{array}$ & $\begin{array}{l}\text { Current } \\
\text { Account } \\
\text { Balance }\end{array}$ & $\begin{array}{c}\text { Overall } \\
\text { Government } \\
\text { Balance }\end{array}$ & GDP/GNP & $\begin{array}{c}\text { External } \\
\text { Dcbt/Debt } \\
\text { Service }\end{array}$ \\
\hline $\begin{array}{l}\text { Date of Latest } \\
\text { Observation }\end{array}$ & $\begin{array}{c}\text { August } 31 \text {, } \\
2002\end{array}$ & $\begin{array}{c}\text { August } 31 \text {, } \\
2002\end{array}$ & $\begin{array}{l}\text { June } \\
2002\end{array}$ & $\begin{array}{l}\text { June } \\
2002 \\
\end{array}$ & $\begin{array}{l}\text { June } \\
2002\end{array}$ & $\begin{array}{c}\text { August } \\
2002\end{array}$ & $\begin{array}{c}\text { July } \\
2002\end{array}$ & $\begin{array}{l}\text { July } \\
2002\end{array}$ & $\begin{array}{c}Q 4 \\
2001 / 02\end{array}$ & $\begin{array}{c}\text { Q4 } \\
2001 / 02 \\
\end{array}$ & $\begin{array}{l}2002 / \\
2001\end{array}$ & $\begin{array}{c}Q 4 \\
2001 / 02\end{array}$ \\
\hline Date Received & $08 / 31 / 02$ & $08 / 31 / 02$ & $8 / 9 / 02$ & $8 / 9 / 02$ & $8 / 9 / 02$ & $9 / 18 / 02$ & $8 / 15 / 02$ & $8 / 15 / 02$ & $8 / 9 / 02$ & $8 / 9 / 02$ & $8 / 9 / 02$ & $8 / 9 / 02$ \\
\hline $\begin{array}{l}\text { Frequency } \\
\text { of Data } 1 /\end{array}$ & $\mathrm{D}$ & $D$ & $\mathbf{M}$ & $\mathrm{M}$ & $\mathbf{M}$ & M & M & $\mathbf{M}$ & $\mathbf{Q}$ & $\mathrm{Q}$ & A & $Q$ \\
\hline $\begin{array}{l}\text { Frequency of } \\
\text { Reporting } 1 /\end{array}$ & D & D & $\mathbf{M}$ & M & $\mathbf{M}$ & M & $\mathbf{M}$ & M & $Q$ & $Q$ & A & $\mathrm{Q}$ \\
\hline $\begin{array}{l}\text { Source of } \\
\text { Update } 2 f\end{array}$ & A & A & A & A & A & A & A & A & A & A & A & A \\
\hline $\begin{array}{l}\text { Mode of } \\
\text { Reporting 3/ }\end{array}$ & $\mathrm{C}$ & C & C & C & C & $\mathrm{C}$ & $\mathrm{C}$ & $\mathrm{C}$ & $\mathrm{V}$ & V & $\mathrm{C}$ & $\mathrm{V}$ \\
\hline $\begin{array}{l}\text { Confidentiality } \\
4 /\end{array}$ & $\mathrm{C}$ & B & C & C & C & $\mathrm{C}$ & $\mathrm{C}$ & $\mathrm{C}$ & $\mathrm{C}$ & $\mathrm{C}$ & C & C \\
\hline $\begin{array}{l}\text { Frequency of } \\
\text { Publication } 1 /\end{array}$ & $\mathrm{D}$ & W & M & M & M & M & M & $\mathbf{M}$ & $\mathbf{Q}$ & $\mathbf{Q}$ & A & $Q$ \\
\hline
\end{tabular}

1/ $\mathrm{A}=$ annually; $\mathrm{Q}=$ quarterly; $\mathrm{M}=$ monthly; $\mathrm{W}=$ weekly; and $\mathrm{D}=$ daily.

2/ $\mathrm{A}=$ direct reporting by central bank, Ministry of Finance, or other official agency

$3 / \mathrm{C}=$ cable or facsimile; and $\mathrm{V}=$ staff visits.

$4 / \mathrm{B}=$ for use by the staff and the Executive Board; $\mathrm{C}$-unrestricted use. 


\section{Pakistan: Trade and Foreign Exchange System Reforms}

\section{Trade system reforms}

The main thrust of the government's trade policies over the past two years has been to reduce anti-export bias and dismantling the remnants of the import substitution policy of the past through trade and tariff liberalization and through the improvement of export financing and infrastructure.

The most significant number of measures taken between late-2000 and August 2002 by the authorities to further liberalize the international trade environment include:

- The number of Statutory Regulatory Orders governing tariff exemptions was reduced from 120 to 56 and the orders governing foreign trade regulations were replaced with only two, namely Exports Policy and Procedures Order and the Import Trade and Procedures Order. In conformity with the latter, the SBP abolished the requirement of opening a Letter of Credit for imports before shipment.

- Procedural requirements for imports of certain restricted goods were simplified so that an importer does not have to obtain a no objection certificate from several government agencies.

- The requirement for an exporter or importer to register with the Export Promotion Board was eliminated and Exporters and Importers Registration Order repealed

- The customs tariff compendium was simplified by deleting 1,200 national tariff lines that were not required for statistical purposes and caused classification disputes.

- The laws governing protection of intellectual property rights (trade marks, patents, copyrights, integrated circuit layouts, and industrial designs) were strengthened.

- With the aim to further simplify import and export procedures, the government established a high-powered National Trade and Transport Facilitation Committee headed by the Secretary of Commerce and including representatives of importers, exporters, shippers, freight forwarders, and other private sector agents.

- To make Pakistani exportable items compliant with international standards (including ISO-9000, ISO-14000, and SA-8000), the government decided to establish Pakistan Compliance Initiative Board with full private sector participation.

A number of steps were taken to liberalize trade in certain goods and commodities:

- Exports and imports of wheat and its milling products were completely liberalized.

- Imports of certain previously restricted textile manufacturers items were allowed. 
- Imports of gold and silver that previously required licensing were completely liberalized.

- Imports of mobile phones, previously allowed only by companies having agreement with the government, were liberalized.

- Imports of used medical and photographic equipment were allowed.

- Exports and imports of petroleum products, previously limited to public sector agencies and approved importers, were completely liberalized.

- Quotas on certain imports from the U.S., E.U., and Canada (categories Cat 369-R, 369-FP, 18, and 8A-1) were eliminated.

- Minimum export price for rice was eliminated while the minimum export price for various counts of cotton was reduced.

- A 15 percent duty on exports of finished leather products was withdrawn.

In addition to reducing the maximum tariff rate from 30 percent to 25 percent, the authorities lowered customs duty on imports of textile and clothing manufacturers, as well as on a number of imported steel products and synthetic fiber, and eliminated the withholding tax on imported supplies. Average custom duties on imported cars were reduced from 155 percent to 125 percent with the last budget, and on motorcycles from 105 percent to 75 percent.

With the aim to provide support to exporters requiring imported inputs and to increase access to export financing by small- and medium-size exporters and their domestic suppliers, the SBP established a new Foreign Currency Export Finance Facility under an AsDB loan to operate alongside the existing Export Finance Scheme.

Overall, Pakistan's openness to foreign trade compares favorably to the countries in the region. The IMF's overall trade restrictiveness index for Pakistan as of September 2002 is six compared to eight for India, Bangladesh, Iran and five for China and Sri Lanka (with one being the most open and 10 fully closed).

\section{Foreign exchange system reforms}

The SBP took the following measures to further liberalize foreign exchange regime and streamline foreign currency transactions regulation:

- Commercial banks and nonbank financial institutions were allowed to utilize freely newly mobilized foreign currency deposits for lending and investment purposes in Pakistan or for placing them abroad.

- Limits on Nostro balances held abroad by Authorized Dealers were abolished. 
- In addition to the branches of banks holding Authorized Dealer licenses, all bank branches throughout the country were authorized to purchase or encash foreign currency notes, travelers checks, and foreign demand drafts presented by the public.

- Authorized Dealers were allowed to issue travelers checks to the public, both residents and nonresidents, against the surrender of an equivalent amount of foreign exchange in cash.

- The requirement that all interbank foreign exchange deals be backed by commercial transactions approved by the SBP was abolished to aliow, inter alia, legitimate market transactions aimed at managing foreign exchange risks by Authorized Dealers.

- The authority to allow remittances against import documents received directly by the importer was transferred from the SBP to the Authorized Dealers.

- The restrictions on domestic borrowing to finance working capital by foreign controlled companies were eliminated. Consequently, Authorized Dealers were allowed to grant Pakistani rupee loans to foreign controlled companies to meet their working capital requirements subject to the observance of prudential regulations.

- The authority to sanction external borrowing by foreign controlled companies to meet their working capital requirements was transferred from the SBP to the Authorized Dealers. In addition, the interest rate cap on such borrowings ( 1 percent over LIBOR) was eliminated.

- $\quad$ Foreign direct investment by residents of Pakistan, including both physical and legal entities, was allowed subject to repatriation of proceeds and with prior permission of the SBP.

- The repatriation period for export proceeds was extended from four to six months.

- The annual quota on the number of tickets domestic airlines and travel agents were allowed to sell to Pakistani nationals for travel by foreign carriers was abolished.

- Limits on foreign exchange payments for travel, education, and health purposes were eliminated.

To liberalize the foreign exchange market further and to remove its segmentation, the SBP decided to transform moneychangers into foreign Exchange Companies (FECs). The establishment of FECs will allow banks to utilize through official channels the moneychanger's network for inward remittances and will provide a proper corporate culture to the moneychanging and remittances business in the country, while ensuring that various types of associated risks are properly addressed and covered. By increasing by more than tenfold the minimum paid-up capital of the company, the SBP expects the moneychangers (currently about 500 licensed moneychangers operate in Pakistan) to consolidate to form a 
limited number of FECs or to become a franchise of a FEC established by commercial banks. A limited number of FECs with sound monitoring framework will not only provide a corporate structure to the currency exchange business but will also help the SBP in effectively regulating their activities. The ordinance establishing FECs was issued in July 2002 and a number of FECs have been already given a no objection certificate allowing them to register with the Security and Exchange Commission of Pakistan.

Unlike moneychangers who were allowed to engage only in domestic cash transactions in foreign exchange, FECs are authorized to transact in foreign exchange in cash, money orders, bank drafts, and inward and outward transfers both within and outside of Pakistan. In addition, FECs are allowed to transact freely among themselves and to participate in the interbank market on the sell side. Also, unlike moneychangers, FECs are allowed to have foreign participation in their equity of up to 50 percent. All transactions between FECs and their customers must be documented by official receipts including the customer identity.

Concomitant with the creation of FECs, the SBP has since mid-2002 redirected its purchases of foreign exchange from the free (kerb) market to the interbank market to further enhance its depth. 


\section{Pakistan: Public and External Debt Sustainability}

1. From nearly 100 percent of GDP in recent years, public debt is expected to fall to 70 percent by $2006 / 07$ under the baseline scenario. Pakistan's public debt hovered about 93-100 percent during the late 1990s, with a jump to 109 percent of GDP in 2000/01, reflecting mostly the impact of the sharp depreciation of the Pakistani rupee in late 2000 on the face value of the external debt. The debt ratio was subsequently reduced to 98 percent of GDP in 2001/02 (Table 1). About half of Pakistan's public debt is external, mostly on concessional terms. The fall in the debt to GDP ratio in 2001/02 resulted from a 2 percent of GDP primary surplus and strong nominal GDP growth of 9 percent relative to the average interest rate ( 7 percent), as well as a 6 percent appreciation of the Pakistan rupee vs. the U.S. dollar. Public debt is expected to fall to 70 percent of GDP by $2006 / 07$ under the baseline scenario. The debt reduction would reflect higher primary surpluses (averaging 2.7 percent of GDP) compared with the preceding 10 years ( 0.1 percent of GDP), predicated upon an increase in the tax ratio by about 1 percentage point to offset a reduction in grants, and strong real GDP growth combined with a slightly declining real average interest rate. Real growth would average 5 percent, compared to 3.4 percent during the preceding 10 years. The scenario thus reflects essentially an assumption that (a) ongoing reforms will succeed in moderately raising real growth; (b) the gains in macroeconomic stability, the rescheduling of official bilateral extemal debts, and reform of the NSS will reduce real interest rates paid on government debt; and (c) tax policy and tax administration reforms will help to raise primary surpluses to close to 3 percent of GDP for the near future.

2. The stress tests indicate that an exploding debt path is not likely under a variety of shocks to the baseline scenario (Stress tests 1 through 7 in Table 1). The stress tests replace the value of key parameters of the baseline scenario by "worse" outcomes (lower growth, higher international interest rates, etc.) while keeping all other parameters unchanged. The time horizon for the projections is again 2006/07. While the process of the debt ratio reduction is slowed down significantly in some of the scenarios, none of the shocks leads to a path of rising debt to GDP ratios. Of particular interest is perhaps the first test, which assumes that the critical parameters remain at the average levels of the last 10 years, rather than improve as projected under the baseline. This could correspond to a situation where further reforms are stalled, or where the recent reforms would not bear fruit as expected. The result that even then debt dynamics would gradually improve reflects, to some extent, the gains made in recent years (for example, a primary surplus during 1999/2000$2001 / 02$ that was far larger than in preceding years).

3. The robustness of these results is checked by increasing the size of the shocks beyond their magnitude in the standard tests (tests 8 through 10 in Table 1). For example, replacing in test parameters by the average values of 1991/92-1997/98, that is excluding the effect of recent reforms, the debt to GDP ratio would stabilize at around 100 percent rather than decline (test 8). Extending some of the other temporary shocks by two or more years would also result in a constant debt to GDP ratio or could even trigger adverse dynamics. These additional scenarios indicate the size of shocks that would turn public debt unsustainable, and 
could be viewed as borderline cases. Strong public finances, retaining the low implicit interest rate on public debt, and achieving high growth, while keeping the exchange rate stable, are obviously the cornerstones of avoiding explosive debt dynamics.

4. A broadly similar picture emerges from the external debt sustainability analysis (Table 2). Here a return to historical performance would trigger a worsening of debt dynamics, while none of the other stress tests (except scenario 2) would trigger such a reversal. This underscores the critical importance of sustaining the reform process to achieve higher growth, and of limiting external borrowing to low-interest sources. As the "historical performance" assumed in test 1 incorporates the strong external adjustment of the last three years, a return to the pre-1999 parameters would trigger a much more dramatic deterioration in debt dynamics, as illustrated in scenario 2. 
Table 1. Pakistan; Consolidated Government Debt Sustainability Framework, 1997/98-2006/07

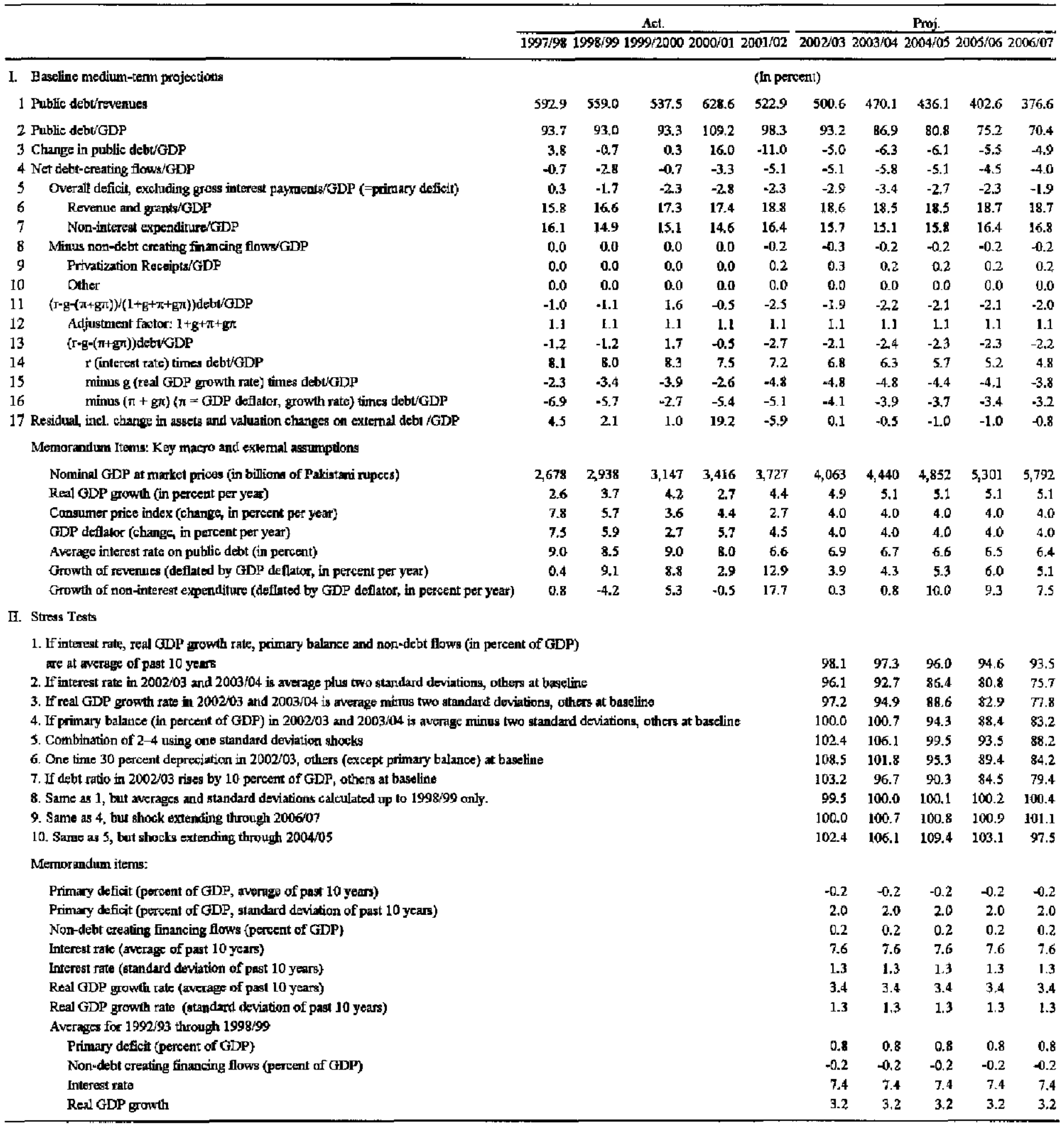

Source: Pakistani authorities; and Fund staff calculations and projections. 
Table 2. Pakistan: External Sustainability Framework, 1996/97-2006/07

\begin{tabular}{|c|c|c|c|c|c|c|c|c|c|c|}
\hline & \multicolumn{5}{|c|}{ Aet. } & \multicolumn{5}{|c|}{ Proj. } \\
\hline & \multirow[t]{2}{*}{$1997 / 98$} & \multirow[t]{2}{*}{ 1998/99 } & \multicolumn{3}{|c|}{$1999 / 200020100 / 012001 / 02$} & \multicolumn{5}{|c|}{$2002 / 032003 / 042004 / 052005 / 0620016 / 07$} \\
\hline \multicolumn{9}{|l|}{ I Baselithe meditarn-term projections } & & \\
\hline I Ratio external public debt to exports of goods and NF services & 289.5 & 331.6 & 310.7 & 318.4 & 300.2 & 286.6 & 268.1 & 248.2 & 227.8 & 210.3 \\
\hline 2 Extennal public sector debt/GDP & 54.3 & 51.5 & 54.6 & 55.8 & 54.5 & 50.5 & 45.5 & 42.1 & 38.5 & 35.3 \\
\hline 3 Change in extemal public-debt debt/GDP & 3.6 & -2.8 & 3.1 & 1.2 & -1.3 & -4.0 & -5.0 & -3.4 & -3.6 & -3.2 \\
\hline 4 Net debt-creating extemal nows/GDP (5+9+12) & 4.7 & -0.5 & 3.5 & -2.3 & -5.1 & -5.2 & -4.8 & -3.8 & -3.6 & -3.3 \\
\hline 5 Current acoount deficit, exchuding interest peyments'GDP & 0.1 & 1.5 & -0.3 & -0.4 & -4.6 & -2.2 & $*[.8$ & .1 .6 & -1.4 & -1.2 \\
\hline 6 Deficit in balance of G\&S/GDP & & & 39.2 & -38.9 & -37.4 & -37.1 & -36.1 & -36.1 & -36.0 & -35.7 \\
\hline 7 Exports of OSS/GDP & 18.3 & 15.5 & 17,6 & 17.5 & 18.2 & 17.6 & 17.0 & 17.0 & 16.9 & 16.8 \\
\hline 8 Impors of G\&S/GDP & -24.0 & -20.6 & -21.6 & -21.4 & -19.3 & -19.5 & .19 .2 & 19.1 & -19.1 & -190 \\
\hline 9 Minus net non-debl creating cepital inflowe/GDP & -1.5 & -0.9 & -1.0 & -0.3 & -0.6 & -0.7 & -0.9 & -0.9 & -0.9 & -0.9 \\
\hline 10 Net foreign direct investment equity/GDP & 1.1 & 0.8 & 0,9 & 0.5 & 0.6 & 0.5 & 0.7 & 0.7 & 0.7 & 0.7 \\
\hline 11 Net portfolio investment, aguity/GDP & 0.4 & 0.0 & 0.1 & -0.2 & 0.0 & 0.1 & 0.2 & 0.2 & 0.2 & 0.2 \\
\hline $12 \quad(\mathrm{~s}-\mathrm{g}-(\rho+\mathrm{g} \rho)) /(1+\mathrm{g}+\rho+\mathrm{g} \rho) \operatorname{debt} / \mathrm{GDP}(14 / 13)$ & 6.2 & -1.1 & 4.8 & .1 .6 & 0.1 & -2.3 & -2.1 & -1.3 & -1.3 & .12 \\
\hline 13 Adjustrikent factor $1+\mathrm{g}+\mathrm{p}+\mathrm{g} p$ & 0.9 & 1.] & 1.0 & 1.1 & 1.0 & 1.1 & 5.1 & 1.1 & 1.1 & 1.1 \\
\hline $14 \quad(5-\mathrm{g}-(\beta+\mathrm{gp})) \mathrm{debt/GDP}(15+16+17)$ & 5.8 & -1.2 & 4.6 & -1.7 & 0.1 & -2.5 & -2.3 & -1.4 & -1.4 & .1 .3 \\
\hline I (interest egte) times debt/GDP & 2.9 & 2.4 & 2.4 & 2.5 & 2.2 & 2.1 & 2.0 & 1.8 & 1.6 & 1.4 \\
\hline minus g (real GDP growth rate) times dobt/GLP & -1.3 & -2.0 & -2.2 & -1.5 & -2.5 & -2.6 & -2.6 & -2.3 & -2.1 & -1.9 \\
\hline mimig $(\rho+g \rho)(\rho=$ U.S. dollar value of GDP deflelor, grawth rate) times debt/GDP & 4.2 & -1.6 & 4.4 & -27 & 0.4 & .20 & -1.8 & -0.9 & -0.8 & -0.7 \\
\hline 18 Resicual, incl change in gross toreign assets'GDP $(3-4)$ & .1 .1 & .2 .3 & -0.4 & 3.5 & 3.8 & 1.3 & -0.2 & 0.4 & 0.0 & 0.1 \\
\hline Memorendum iterns: key maero and external assunptions & & & & & & & & & & \\
\hline Norninal GDP (in billions of Pakistani nupees') & 2,678 & 2,938 & 3,147 & 3,416 & 3,727 & 4,063 & 4,440 & 4,852 & $5,30 !$ & 5,792 \\
\hline Nominal GDe (in billions of U.S. dolkars) & 53.4 & 56.9 & 54.5 & 58.6 & 60.8 & 66.7 & 71.8 & 76.7 & 82.1 & 87.7 \\
\hline Real GDP growth (in peroent per year) & 2.6 & 3.7 & 4.2 & 2.7 & 4.4 & 4.9 & 5.1 & 5.1 & 5.1 & 5.1 \\
\hline Nontinal GDP deflator (in U.S. dollars, ohmig in percent per year) & -8.1 & 2.8 & -82 & 4.8 & -0.6 & 3.6 & 3.3 & 1.8 & 1.8 & 1.8 \\
\hline External interest rate (percent per year) & 5.8 & 4.4 & 4.7 & 4.6 & 4.0 & 3.9 & 4.0 & 3.9 & 37 & 3.6 \\
\hline Growth of exports of G\&S (U.S. dollar teims, ith percent per year) & 2.4 & .11 .7 & 8.3 & 7.4 & 7.4 & 5.5 & 4.6 & 6.9 & 64 & 6.2 \\
\hline Growth of imports of G\&S (U.S. dollar teme, in percent per year) & -11.1 & -8.4 & 0.2 & 6.6 & -6.5 & 100 & 6.7 & 6.8 & 66 & 6.3 \\
\hline II. Scnsitivity Analyais for External Public Debtto-GDP Ratio & & & & & & & & & & \\
\hline $\begin{array}{l}\text { 1. If interest rate, real GDP gnowth rate, U.S. dollar GEP deflator growth, non-interest eurren } \\
\text { and non-debt flows (in percent of GDP) are at average of past } 10 \text { years. }\end{array}$ & account, & & & & & $\$ 6.8$ & 57.8 & 59.3 & 60.5 & 61.8 \\
\hline 2. If interest rate, real GDP growth rate, U.S. dollar GDP deflator growth, non-interest curren & account, & & & & & & & & & \\
\hline and non-debt flows (in percent of ODP) are \& average over the paiod 1992/93-1998/99 & & & & & & 57.9 & 59.9 & 62.5 & 64.8 & 57.3 \\
\hline 3. If interest fate in 2002 and 2003 is weroge plus two standard devistions, othros at baseline & & & & & & 57.8 & 47.9 & 44.4 & 40.7 & 37.5 \\
\hline 4. If real GDP growth rate in 2002 and 2003 is average minus two standard deviations, others & it baseline & & & & & 52.7 & 49.8 & 46.2 & 42.5 & 39.2 \\
\hline 5. If U.S. dollar GDP deflator in 2002 is average minus two standard deviations, others at bas & & & & & & 60.9 & 55.4 & 51.7 & 47.8 & 44.3 \\
\hline 6. If thot-interest current accouns (in percest of GDP) in 2002 and 2003 is average minus two & standard de & iations, & others at bas & elıne & & 59.8 & 63.3 & 59.4 & 55.2 & 51.5 \\
\hline 7. Combination of 2-5 using one stendard deviation shocks & & & & & & 65.5 & 68.8 & 64.7 & 60.4 & 56.5 \\
\hline 8. One time 30 percent depreciation in year 2002 (-30 percest GDP deflator shock), others at & aaseline. & & & & & 75.6 & 69.5 & 65.4 & 61.1 & 57.1 \\
\hline Memorandurn items : & & & & & & & & & & \\
\hline Current axcount deficit, excluding interest peyments (porcent of GDP, gverage of pest 10 & eats) & & & & & 1.2 & 1.2 & 1.2 & 1.2 & 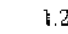 \\
\hline Current account deficit, excluding interest payments (persent of GDP, standard deviation & of past $10 \mathrm{y}$ & ears) & & & & 29 & 2.9 & 2.9 & 2.9 & 29 \\
\hline Net non-debt creating capital inflows (percent of GDP, averege of past 10 years) & & & & & & 1.3 & 1.3 & 1.3 & 1.3 & 1.3 \\
\hline Interest rate (average of past 10 years) & & & & & & 5.1 & 5.1 & 5.1 & 5.1 & 5.1 \\
\hline Interest rate (standard deviation of past 10 years) & & & & & & 0.7 & 0.7 & 0.7 & 0.7 & 0.7 \\
\hline Real GDP growth rate (werage of past 10 years) & & & & & & 3.4 & 3.4 & 3.4 & 3.4 & 3.4 \\
\hline Real GDP growth rata (stenderd deviation af past 10 years) & & & & & & 1.3 & 1.3 & 1.3 & 1.3 & t.3. \\
\hline GDP deflator, U.S. dollin terms (average of past 10 years) & & & & & & -0.5 & -0.5 & -0.5 & -0.5 & -0.5 \\
\hline GDP deflator, US. dollar terms (standard deviation of pust 10 years) & & & & & & 6.5 & 6.5 & 6.5 & 6.5 & 6.5 \\
\hline
\end{tabular}

Source: Pakistani authorities; and Fund staff caleulations and projoctions. 
October 16, 2002

Mr. Horst Köbler

Managing Director

International Monetary Fund

Washington, D.C. 20431

U.S.A.

Dear Mr. Köhler:

The Pakistani authorities held discussions with Fund staff in August 2002 for the third review under the PRGF Arrangement. Based on these discussions, the attached Memorandum of Economic and Financial Policies (MEFP) reviews economic developments and policy implementation through August 2002 under the arrangement, updates the macroeconomic framework, and discusses the financial policies and structural reform program for the remainder of the fiscal year 2002/03. It supplements the MEFP dated November 22, 2001 as well as the supplementary MEFPs dated March 12, 2002 and June 18, 2002.

All performance criteria for end-June 2002 and for July and August 2002 were met, except for the three performance criteria on the Central Board of Revenue (CBR) revenue for total revenue through June 2002, on bringing Karachi Electric Supply Corporation (KESC) to the point of sale by end-July 2002 , and on not granting any new tax exemptions. We request waivers for the nonobservance of the performance criteria, and a modification of the December 2002 target for CBR revenue, on the following grounds:

As detailed in the MEFP, and already anticipated in the June-MEFP, the CBR revenue shortfall mostly reflects the lower-than-expected imports during January-March. Despite a strong recovery of tax receipts during April-June, this shortfall could not be made up. A range of tax policy and tax administration reforms have been implemented with the fiscal year 2002/03 budget, to strengthen tax collection. The turnaround in revenue performance that started in March 2002 has accelerated in July-September, along with a recovery of exports and imports, and preliminary data indicate that the end-September target for CBR revenue was met.

On KESC, the government has taken the critical measures under its control, as detailed in the MEFP, to bring KESC to the point of sale. However, only two investors have expressed preliminary interest, and none is prepared to enter into due diligence at this stage. We remain hopeful that once security concerns subside and international equity markets stabilize, investor interest will strengthen and allow pursuit of the privatization strategy. In the meantime, as set out in the MEFP, a number of measures are being implementec to address the financial imbalances of KESC and reduce regulatory uncertainty. 
Finally, for what we think are technical as well as socio-political reasons, detailed in the attached MEFP, we have eliminated the sales tax on medicines that was introduced earlier in the year. Nonetheless, the overall quarterly tax revenue targets remain unchanged, and will be secured by end-October.

On the basis of the performance up to July 2002 and the policies set out in the attached memorandum, the government requests the completion of the third review. We expect the fourth, fifth, and sixth reviews under the arrangement to be completed as scheduled by endDecember 2002, end-March 2003, and end-June 2003, respectively.

The government of Pakistan will provide the Fund with such information as the Fund may request in connection with Pakistan's progress in implementing the economic and financial policies, and achieving the objectives of the program. The government believes that the policies set out in the attached memorandum are adequate to achieve the objectives of the program. However, we stand ready to take any additional measures appropriate for this purpose, and will consult with the Fund in accordance with the policies of the Fund on such consultations.

\section{Sincerely yours,}

$\mathbf{S}$

Shaukat Aziz

Minister of Finance and Economic Affairs s

Ishrat Husain

Governor

State Bank of Pakistan

Attachment:

Memorandum of Economic and Financial Policies 


\section{PAKISTAN}

\section{Memorandum of Economic and Financial Policies for the Remainder of FY 2002/03}

\section{Developments During May-August 2002}

1. Despite several adverse external and internal shocks, such as the continued impact of post September 11 events, drought, high oil prices, and security problems, economic adjustment and reform have maintained a strong momentum. Continued private foreign exchange inflows and steady financial support by the international community have allowed the banking system to buildup foreign exchange reserves to a level that considerably reduces the economy's vulnerability to external shocks. All performance criteria for end-June 2002 and for July and August 2002 have been met, except - for reasons detailed below - the Central Board of Revenue (CBR) revenue target; the structural performance criterion on bringing Karachi Electric Supply Corporation (KESC) to the point of sale (Tables 1(a) and 2(a)); and the continuous performance criterion on the non-introduction of new tax exemptions. However, regional tensions and isolated domestic terrorist acts remain impediments to a faster recovery of private investment and growth. Technical assistance has in some cases slowed down because of travel advisories. Recent constitutional amendments aim to ensure the continuity of core reforms of recent years, while parliamentary elections planned for October 2002 provide an opportunity to strengthen involvement of the political forces in the formulation and implementation of the reform program, and to deepen program ownership.

2. Macroeconomic developments remain broadly in line with the program. The consumer price index (CPI) increased by 3.7 percent over the year through August 2002, consistent with program assumptions. Preliminary data indicate that real GDP growth (at factor cost) for the fiscal year that ended in June 2002 reached 3.6 percent, slightly better than expected at the time of the last review. Driven by the surge in workers' remittances, real GNP grew even faster, at an estimated 5.4 percent. Regarding poverty developments, quantitative evidence will become available only once the planned strengthening of the monitoring of social sector developments is implemented (see below). However, we believe that devolution has gotten off to a good start in strengthening the delivery of social services.

3. The balance of payments position has continued to improve. Available trade data (on a customs basis) through August 2002 confirm the strong recovery in trade since March, and the other trends described in the June 2002 MEFP also remain intact, including strong remittances and private capital inflows. Thus, official reserves reached US\$5.3 billion at endAugust 2002, the Pakistani rupee has remained broadly stable vis-à-vis the U.S. dollar, and the spread between the kerb and interbank markets has remained virtually nil. Since June 1, 2002, foreign exchange purchases of the State Bank of Pakistan (SBP) have been confined to the interbank market. 
4. Broad money grew strongly through June 2002 , despite considerable efforts at sterilization. The end-June 2002 ceiling for net domestic assets (NDA) of the central bank and the floor on net foreign assets (NFA) were respected with wide margins, and the ceiling on public enterprise borrowing was also observed. However, broad money growth accelerated to 15.9 percent in the year through June 2002 (from 13.8 percent through March), driven by large foreign exchange inflows. Given the stable exchange rate and low, albeit slightly rising, inflation, we continue to view this monetary expansion as mainly a structural shift to higher money demand reflecting increased confidence in the domestic currency. In response to a modest pickup of year-on-year inflation from 1.8 percent in December 2001 to 3.2 percent in June 2002, to counter the risk of a reemergence of inflationary pressures, we moved toward a more active absorption of liquidity in recent months, and have kept the discount rate stable at 9 percent since February 2002. This belped to slow reserve money growth to 9.7 percent in the year to June 2002, from 14.3 percent in December 2001.

\section{The end-June 2002 fiscal deficit performance criterion was observed, despite a} shortfall in CBR tax collection. The budget deficit (excluding grants and one-off capitalization outlays) was contained to PRs 189 billion (5.1 percent of GDP), 0.6 percent of GDP lower than programmed. Cumulative CBR revenue through June 2002 fell short of the program target by about $P R s 10$ billion (or 2.5 percent). Although better than anticipated during the second review, the acceleration of CBR revenue growth since March 2002 proved insufficient to make up the shortfall carried over from the preceding quarter. Nonetheless, this better-than-expected outcome confirms the basis for this fiscal year's targets, and with a strong performance in July-August (where CBR revenue rose by 14 percent over last year), these targets appear attainable. Nontax revenue for FY 2001/02, including compensation for services to the coalition in the fight against terrorism, was well above expectations, mostly on account of higher dividends from public sector enterprises (PSE), and despite lower-thanexpected interest payments from the Water and Power Development Authority (WAPDA). WAPDA's financial difficulties also led to its inability to make principal repayments on outstanding government loans to the budget. All in all, budgetary support for WAPDA in FY 2001/02 reached PRs 18.5 billion (0.5 percent of GDP). Defense expenditures were contained slightly below the anticipated levels. Interim Poverty Reduction Strategy Paper (I-PRSP) expenditure accelerated strongly in the last months of the fiscal year as the newly elected local governments became fully operational, indicating that their ability to spend on social services while respecting proper accounting standards has improved sharply. According to preliminary (non-reconciled) data, Interim Poverty Reduction Strategy Paper expenditure rose by 9.1 percent above the levels of the preceding year, reaching PRs 133.5 billion for the year ending June 2002 ( 3.6 percent of GDP), only marginally lower than the programmed levels and compared to a shortfall of 25 percent during July-December 2001. Education spending, which accounts for nearly half of the total I-PRSP outlays, was up 17 percent over last year, health spending was up 10 percent. However, reconciliation of the district accounts will take a few months and only then will fully reliable data on the exact composition of actual cash expenditure become available. 
6. Structural reforms are broadly on track, as detailed in the attached Table 2(a). All structural performance criteria for July 1 were met. As specified in the November 2001 MEFP, the cabinet approved a privatization plan for KESC in February 2002. KESC filed a tariff petition with the National Electricity Power Regulatory Authority (NEPRA) in May 2002 for a multi-year tariff to provide long-term confort to prospective investors. The Privatization Commission started transaction procedures in March 2002 with advertisements and direct contacts by the financial advisor and called for expressions of interest (EOI) and statements of qualifications (SOQ) from prospective investors with closing date on June 24, 2002. In May 2002, a marketing conference (road show) was held in Karachi. Despite travel advisories, global corporate uncertainties, and the post-September 11, 2001 scenario, two investors submitted their EOIs. One of them also submitted the SOQ in June 2002. None of the investors who expressed interest has yet initiated due diligence, although all data are ready from our side. While all the critical steps toward privatization that were under our control were taken, the performance criterion on bringing KESC to the point of sale by end-July, as specified in the November 2001 MEFP, was thus missed for reasons related to third parties outside our control. Nonetheless, a number of privatizations in the oil and gas sectors and of United Bank Limited (UBL) were concluded, and the process of privatizing other major enterprises is gathering momentum. With the presentation of the budget, we published a draft fiscal responsibility law, inviting comments from the general public by July 15, several of which are now being incorporated. The law prescribes the budget statements that the federal government has to provide on a regular basis, and sets a number of rules and targets for fiscal policy to ensure fiscal transparency and sound fiscal management.

7. The reorganization of WAPDA has made progress. The financial improvement plan (FIP) for WAPDA recently agreed upon with the World Bank, which covers the period July 2002 through June 2004, is broadly on track, since a structural average tariff increase was recently granted by NEPRA and became effective on August 13,2002. The increase (9.2 percent on average) is somewhat below the Financial Improvement Plan (FIP) target (12.8 percent) in order to protect the most vulnerable consumers through low increases in the low-consumption slabs. With offsetting savings expected from greater availability of hydroelectrical power and assuming full implementation of the FIP, WAPDA should need only a small amount of budgetary support in this fiscal year (see below). National Electricity Power Regulatory Authority also issued licenses to the new distribution companies (DISCOs) and generation companies (GENCOs), and the transfer of assets and liabilities to the new companies is now largely complete. A request for a tariff increase was filed by KESC, and following approval by NEPRA, a 6.5 percent average structural increase became effective September 13, 2002.

8. The Supreme Court of Pakistan on June 24, 2002 set aside its earlier judgment of December 1999 on "riba" and remitted all the cases to the Federal Sbariat Court, the court of first instance, for determination anew. In late September 2002, the cabinet adopted amendments to the SBP Act that increase the SPB's independence, in particular in the area of reserve management, and in line with Fund Safeguards Assessment recommendations. 


\section{ECONOMiC and Financial Policies for FY 2002/03}

\section{A. Macroeconomic Objectives and Policies}

9. A new government will emerge from the parliamentary elections in October 2002. We expect that because the reform package commands broad consensus across the political spectrum, economic gains are now beginning to be visible, and recent constitutional changes emphasize the need to maintain sustainable macroeconomic policies, the momentum of reforms will continue. We are confident that the thrust of economic policies set forth below will be implemented as envisaged, and that the next government will, by early 2003 , finalize a full-fledged poverty reduction strategy, providing the basis for continued support through the Poverty Reduction and Growth Facility (PRGF) arrangement.

10. Despite concerns about the strength of the international recovery, recent data confirm the expected upturn in domestic economic activity, and we remain confident that the original macroeconomic objectives under the program for FY 2002/03 will be achieved. Real GDP growth (at factor cost) is still projected to reach 4.5 percent in FY 2002/03. Provided security concerns subside, we expect an 8 percent increase in exports (in U.S. dollar terms) over the last fiscal year, consistent with recent trends. Export growth is expected to be underpinned by some improvement in unit prices, a shift to higher valueadded products in the textile sector, and the recent improvement in access to major trading partner markets. Building on recent price developments, and assuming broad stability of the exchange rate and international oil prices, our objective to contain inflation at 4 percent remains unchanged. Rising imports related to the pickup of domestic activity as well as a return of remittances and official transfers closer to historical trends are expected to move the external current account (including official transfers) from a surplus of 2.5 percent of GDP to a balanced one in FY 2002/03. This change will be partly offset by a lower capital account deficit, largely because of lower public sector net short-term outflows (including lower repayment of trade credits and of frozen foreign currency deposits following higher-thanexpected repayments in FY 2001/02). However, we expect private net inflows to ease off from the exceptionally high levels of FY 2001/02, which we view partly as a portfolio shift of Pakistani balances abroad toward the domestic financial system, partly reflecting a shift of previously unrecorded inflows toward official channels. Net exceptional financing, notably in the form of rescheduled debt service payments and program financing from the International Financial Institutions (IFIs), will be somewhat lower than in FY 2001/02, at about US $\$ 2.5$ billion. While reserve accumulation is expected to be less than during 2001/02, gross official reserves are projected to rise to at least US\$5.3 billion in June 2003, equivalent to almost five months of next year's imports of goods and nonfactor services.

11. As outlined in the June 2002 MEFP, we will maintain the current policy mix combining a flexible exchange rate and prudent monetary policy geared toward achieving the inflation and reserves targets, and further fiscal consolidation to extricate Pakistan from excessive levels of public debt. Given that the recent decline in the income velocity of money may be only a temporary phenomenon, we will continue to closely monitor 
inflation indicators as well as monetary aggregates. We have already shifted toward the pursuit of a more aggressive absorption of liquidity, and have revised downward the targets for broad money and reserve money growth, in line with projected nominal GDP growth. In view of the volatility of monetary aggregates and their unstable relation with inflation, we are pursuing preparatory work to explore the option of moving to an inflation targeting framework over the medium term.

\section{Fiscal policies aim to reduce the consolidated govermment cash budget deficit} (excluding grants and with interest on accrual basis) to 4.7 percent of GDP, from 5.1 percent in 2001/02, while substantially raising social expenditure to reduce Pakistan's "social gap." The deficit target incorporates the settlement of KESC's debt to banks and suppliers, in the context of its privatization strategy, of PRs 11 billion, for which the program provides an adjuster (to the deficit target); the target remains thus in line with the original program objective of a deficit of 4.4 percent of GDP. As detailed in the June 2002 MEFP, we expect the deficit reduction to result mostly from an increased tax effort and sharply reduced budgetary support for WAPDA and KESC. However, the projected composition of expenditure has been revised to allow additional support for public enterprise reform, with offsetting savings in the foreign interest bill (reflecting some debt data revisions and lower-than-expected interest rates on debt restructured under the Paris Club agreement), and higher federal nontax revenue on the expectation that WAPDA will pay in full its debt service to the budget. The additional subsidies/grants include additional budgetary support for KESC (PRs 11.5 billion, or 0.3 percent of GDP), due mainly to a later-than-expected electricity tariff increase and assuming a delay in KESC privatization to December 2002, including the settlement of KESC's arrears to suppliers (notably WAPDA). WAPDA will receive a subsidy to partly compensate for the delayed electricity tariff increase (PRs 0.7 billion). The fleet renewal of Pakistan International Airline (PLA) requires an additional grant (PRs 2 billion), and in the context of a major reform of rural finance institutions, PRs 6 billion have been allocated to the restructuring of the Agricultural Development Bank of Pakistan (ADBP) (see below).

\section{Should unforeseen developments threaten the fiscal deficit target, we plan to} reduce nonpriority expenditures, while striving to protect the budgeted increase in I-PRSP expenditures. One main risk would be a prolongation or escalation of tension on the eastern border that could constrain our ability to achieve the fiscal targets. Barring such developments, we intend to reduce the share of defense expenditure in relation to GDP to about 3.6 percent, from 4.0 percent in 2001/02. Another risk is that for various reasons, KESC and/or WAPDA may not achieve the planned efficiency gains, such as the envisaged reduction in theft and technical losses or improvements in bill collection from FATA. For example, additional budgetary outlays of up to PRs 5 billion would be required if KESC were not privatized during this fiscal year. Furthermore, as set out in the June $2002 \mathrm{MEFP}$, an excess in external budgetary cash grants plus capital grants over programmed levels may be used for additional expenditure on I-PRSP categories, for up to 0.5 percent of GDP. 


\section{B. Structural Policies}

\section{Tax policy and tax administration}

14. As described in the June 2002 MEFP, a substantive tax reform package has become effective with the FY 2002/03 budget, and is being complemented by revamping business procedures within the CBR. As a first step, the large taxpayer unit (LTU) in Karachi has become operational and is now treating the files of major taxpayers on the basis of greater functional integration of the administration of all taxes. Specific recommendations on bow to revamp CBR's human resource management (recruitment procedures, a move to more merit-based promotion and remuneration rules) and bow to make better use of modern information technology will be prepared with the help of World Bank-financed consultants by November 2002. Effective August 23, 2002, we eliminated the GST on medicines introduced in March 2002 for two reasons: First, it became evident that the tax did not command sufficient social or polirical consensus and contributed to a weakening of public support for the entire adjustunent program. Second, following the exemption of a large number of "life saving" drugs, the administration of the tax became extremely complex. To offset the revenue losses from the elimination of the GST on medicines (about PRs 2.5 billion on an annual basis), we will adjust taxation of various petroleum products, to yield about PRs 2.5 billion additional revenue on an annual basis. We look forward to review shortly with planned Fiscal Affairs Department (FAD) technical assistance missions progress to date on the various tax reforms, and formulate specific actions for the second half of the fiscal year, with focus on customs reform (where a draft reform plan has been prepared), refund procedures, and other administrative reform.

\section{I-PRSP implementation, public expenditure management, and fiscal transparency}

\section{I-PRSP implementation and reforms on improving fiscal transparency and data} quality are proceeding as detailed in the June 2002 MEFP. The recently established I-PRSP secretariat has intensified the monitoring of pro-poor (that is, I-PRSP) expenditures, which are now reported to the public on a quarterly basis. The secretariat will work with the provincial governments to improve their capacity to conduct qualitative analysis of expenditure patterns and take remedial policy action as needed. Specific proposals for setting up mechanisms to monitor intermediate poverty indicators have been worked out with the World Bank and the U.K. Department for International Development (DFID), and will become operational by end-2002. We will continue to implement fiscal transparency and data quality measures in line with establishing an Accountable Fiscal Management Framework (AFMF) and in the context of the Pakistan Improvement of Financial Reporting and Accounting (PIFRA) project. At the provincial level, fiscal transparency and data work are being supported through World Bank provincial structural adjustment loans. The main challenge will be to ensure timely and reliable reporting and reconciliation of expenditure data at the district level, through capacity building at the local government level (supported 
by the AsDB (Asia Development Bank)) and other international organizations; and strengthening the comptroller general of accounts (CGA) as planned under Pakistan Improvement of Financial Reporting and Accounting (PIFRA).

\section{Other governance reforms}

16. Improving governance remains at the center of our economic strategy and informs the ongoing reforms in the areas of devolution, civil service, tax policy and administration, and public financial management, as well as our ambitious privatization program. An international workshop in August discussed a National AntiCorruption Strategy, prepared by the National Accountability Bureau, which will be taken to the cabinet for further consideration, with specific actions to be planned on this basis. The reform of police and the judiciary under an AsDB-supported program is off to a good start with improved allocations for police and judicial reform in this year's provincial budgets; preparation of a draft "Freedom of Information" Act; and passage of a police ordinance clarifying the role and powers of the police consistent with devolution, including the constitution of local citizen boards to enhance oversight over the local police. Another AsDB-supported program, currently under negotiation, aims to strengthen corporate governance in the nonbank financial sector (notably insurance and pension funds). Public procurement reform got under way in May 2002 with the passage of a law establishing the Public Procurement Regulatory Authority, which will have the task to ensure enforcement of clear and transparent procurement rules.

\section{Public enterprises}

17. The privatization program has partly overcome the setbacks following the events of September 11. However, the privatization of Pakistan Telecommunications Company Limited (PTCL) is being delayed due to limited investor interest in the context of the weak financial position of the international telecommunication sector, since so far none of the interested investors fully complies with the required qualifications. We hope to complete the privatization of KESC before end-2002. Discussions with at least one interested investor are being pursued and various complementary reforms are being put in place to reduce regulatory uncertainty. These include the write-down of capital and clarification of the respective responsibilities of NEPRA and the monopoly commission. These steps would also constitute the basis for an alternative restructuring strategy, should privatization at this time prove impossible. Various other PSEs are being prepared for privatization in the near future. In particular, expressions of interest have been received for the Oil and Gas Development Corporation (OGDC), Habib Bank Ltd. (HBL), and Pakistan State Oil (PSO). Due diligence by qualified investors will likely proceed during September-October, with bidding expected shortly thereafter. To enhance PSE monitoring and accountability, we have worked out quarterly performance targets for PIA, Pakistan Railways, Pakistan Steel Mills, and WAPDA/successor companies. The performance of WAPDA, in particular, is being closely monitored by a ministerial committee to ensure improvements in line losses and billing/collection as planned. Given the uncertainty over the timing of its privatization, we 
have prepared a similar plan for KESC for this fiscal year, with quarterly public reporting to start in November and covering the first quarter of FY 2002/03. The plan provides for cash deficits consistent with the budgetary support discussed above. We are pleased that strong governance reforms in recent years have helped to tum around the financial performance of many PSEs, in particular the national airline (PIA), the railways, and Pakistan Steel. We have endorsed a business plan prepared by PIA that aims to increase efficiency further, including greater focus on its core business (by selling its real estate holdings and outsourcing) and renewal of the fleet. We are also working, in close consultation with the World Bank, on a plan to incorporate the railways (currently operated as a government department) and to involve private sector financing where possible, for a planned modernization program.

\section{Agriculture and marketing reforms}

18. As set forth in a policy statement to be issued shortly, our strategy in agriculture centers on further improving water management, providing better extension services to raise yields and reduce vulnerability to drought and pests, and gradually reducing government involvement in the marketing of agricultural commodities, as specified in a reform program supported by an AsDB loan. In order to encourage the private sector to assume a greater role, especially in investing into wheat storage facilities, we have put in place an incentive package as detailed in the June 2002 MEFP. We are quite encouraged by initial results, as the private sector has now, for the first time in recent history, become involved in wheat marketing, exporting about 0.5 million tons.

\section{Financial sector and exchange system reforms}

19. Banking sector reform is continuing in accordance with our financial sector strategy. At its core is the reform of seven public sector financial institutions (United Bank Limited, Habib Bank Ltd., National Bank of Pakistan (NBP), Allied Bank of Pakistan (ABP), National Development Finance Corporation (NDFC), Agricultural Development Bank of Pakistan, and Industrial Development Bank of Pakistan (IDBP)), which account for 80 percent of nonperforming loans of the entire banking system. The reform involves several specific action plans.

- Following extensive restructuring of the branch networks, staffing, and balance sheets of the three nationalized banks, we are about to complete the sale of 51 percent of shares in UBL to a strategic investor. The remainder of the SBP's holdings in UBL will be floated subsequently in light of market conditions.

- We have invited expressions of interest for the sale of Habib Bank, which will lead to its eventual sale to the private sector.

- We plan to float another 5-10 percent of NBP shares, reducing the government's share to about 80 percent. 
- The planned disposal of the government's minority holding in Allied Bank ( 49 percent) has been delayed since a number of unexpected legal complications are being resolved, but we remain committed to sell it to a strategic investor.

- We have already liquidated the NDFC and merged its residual functions with NBP.

- With technical and financial support from the AsDB, we have embarked on the restructuring of the $\mathrm{ADBP}$ which involves downsizing to half the current staff through a voluntary separation program; appointing a board drawing on professionals from the private sector; and recapitalization through conversion of outstanding government loans into equity. We are aware that maintaining ADBP as a publicly-owned corporation carries risks, notably that it will prove difficult to turn around the performance of the staff kept on payroll, or that eventually its lending and staffing will again become dominated by noncommercial considerations, which in the past has led to its current insolvency. We believe, however, that given ADBP's critical role in the rural sector, the immediate liquidation of ADBP would have had unacceptable social costs. As other rural finance institutions are being developed under the AsDB program, we will, after two years, review the possibility of privatizing ADBP or if needed consider its liquidation.

- We are also considering restructuring and privatization of the IDBP since it holds a commercial banking license and should be attractive to private investors.

20. The aforementioned Supreme Court decision has cleared the way for pursuing an evolutionary approach to Islamic finance, through encouraging the development of Islamic banking alongside traditional financial institutions, while adapting regulations for the supervision of chartered Islamic banks. We remain disappointed that the Fund and the World Bank have again delayed the planned Financial Sector Assessment Program (FSAP) mission, but we will seek every opportunity to discuss with the Fund our strategy on (a) protecting the financial system against illicit use, by bringing anti-money laundering (AML) rules up to best practices; (b) further modernizing the prudential framework; and (c) phasing out the remnants of administered credit allocation (such as prescribed lending to agriculture). A draft AML law has been prepared and will be promulgated before October 2002. It includes provisions to criminalize money laundering, to set up a financial intelligence unit, and to allow freezing and forfeiture of assets and international cooperation. In order to further strengthen the regulatory and supervisory framework and promote consumer financing and lending to smalland medium-sized enterprises (SME), the SBP is formulating separate prudential regulations for these two types of lending. The SBP has already removed certain impediments that stood in the way of consumer financing by the nationalized commercial banks. A study on housing finance has been completed and the commercial banks are embarking on developing new mortgage products. In the context of a capital market reform program supported by another AsDB loan, we plan a number of steps to strengthen stock market supervision, develop secondary markets for government paper, strengthen corporate governance in the nonbank 
financial institutions, and pursue the reform of the National Saving Schemes (NSS) to reduce remaining distortion and further lower the budgetary cost of such debt.

21. The legal and regulatory framework for the transformation of moneychangers into foreign exchange companies (FECs) has been promulgated in July 2002. Existing moneychangers will have two years to register as FECs and comply with relevant prudential rules/capital requirements, but no new licenses for moneychangers will be issued. After the two-year period, no moneychanger will be allowed to operate unless registered as FECs. The FEC will be allowed to effect inward transfers. Banks have been allowed, effective February 1,2002, to purchase foreign exchange from moneychangers at freely negotiated rates, thus moving further toward unification of the interbank and the kerb market. We expect all major moneychangers to convert within the next few months; commercial banks are also in the process of setting up FECs as subsidiaries. We expect the FECs will, over time, also absorb much of the legitimate transfer business currently going through the Hawala system.

\section{Financing Issues}

\section{While official reserves have been rising much faster than expected at the launch} of the PRGF-supported program, the further accumulation called for under the revised program is warranted in view of the many risks to our economy, most notably those related to regional tensions. We are confident that the revised program remains fully financed for FY 2002/03. Ongoing discussions with all creditors aim at concluding the bilateral agreements implementing the recent Paris Club Agreed Minute, and ensuring treatment of debt due to non-Paris club bilateral creditors on terms comparable to those agreed with the Paris Club creditors. While these discussions are well advanced, they could not yet be concluded, in part due to travel advisories, and Paris Club creditors recently agreed to extend the target date for conclusion of these agreements to December 31, 2002. Partner countries and multilateral institutions have voiced strong support for the reform strategy laid out in the I-PRSP, and we expect to obtain financial support at least at the levels assumed in the program, sizable debt swaps (for social expenditure) in the context of the aforementioned bilateral debt restructuring agreements, and in some cases outright debt cancellation. We are also firmly determined to meet the conditionality attached to program loan disbursements with the AsDB and World Bank to ensure the projected disbursements are on time.

\section{DATA Issues}

23. In the context of the project to revise and change the base year of the national accounts, the last three studies, including on saving and investment, were recently completed and sent to Fund staff for comments. Publication of a producer price index (PPI) is scheduled to commence in late 2002. Recent steps toward improvement in statistical data dissemination include the publication of an advance release calendar for selected statistical data; and dissemination of quarterly balance of payments statistics (with one quarter lag) and of monthly analytical accounts of the SBP in the format called for under Special Data 
Dissemination Standard (with a one-month lag). We expect to finalize an institutional reform plan for the statistical system by early 2003 , consolidating various existing statistical agencies into one agency with enhanced autonomy. We are working on the cleaning up and consolidation of the latest Pakistan Integrated Household Survey (PIHS) data to allow an updated analysis of social- and poverty-related developments internally, as well as by international organizations and researchers, including the delayed social impact assessment for selected reform under the I-PRSP to be conducted jointly with the World Bank and the Fund.

\section{Program Monitoring}

24. The proposed performance criteria and indicative targets through end-June 2003 are set out in Tables 1(b) and 2(b). Table 2(a) reports on the status of the existing structural performance criteria and benchmarks; Table 2(b) includes the additional conditionality proposed as well as the actions we intend to take prior to the Board discussion of the third review. Further actions will be developed in the next reviews based, in particular, on input from the planned technical assistance on CBR reform; formulation of specific actions emerging from our anti-corruption strategy; and public enterprise reform once the prospects for some of the more difficult privatizations have become clearer. This will also allow the new government to take full ownership of such steps. The attached amendments to the Technical Memorandum of Understanding (TMU) of June 2002 apply effective January 1, 2003 and clarify the treatment of the privatization accounts at SBP and NBP, and update the baseline assumptions for external program financing, external grants, and deposit reserve requirements. We expect the fourth review to take place as scheduled by endDecember 2002. The review will focus on public enterprise finances and public expenditure monitoring, especially I-PRSP spending.

Attachment: Amendments to TMU 


\section{Table 1(a). Pakistan: Quantitative Targets, March-June 2002 1/}

(Cumulative flows from July 1, 2001; unless otherwise specified)

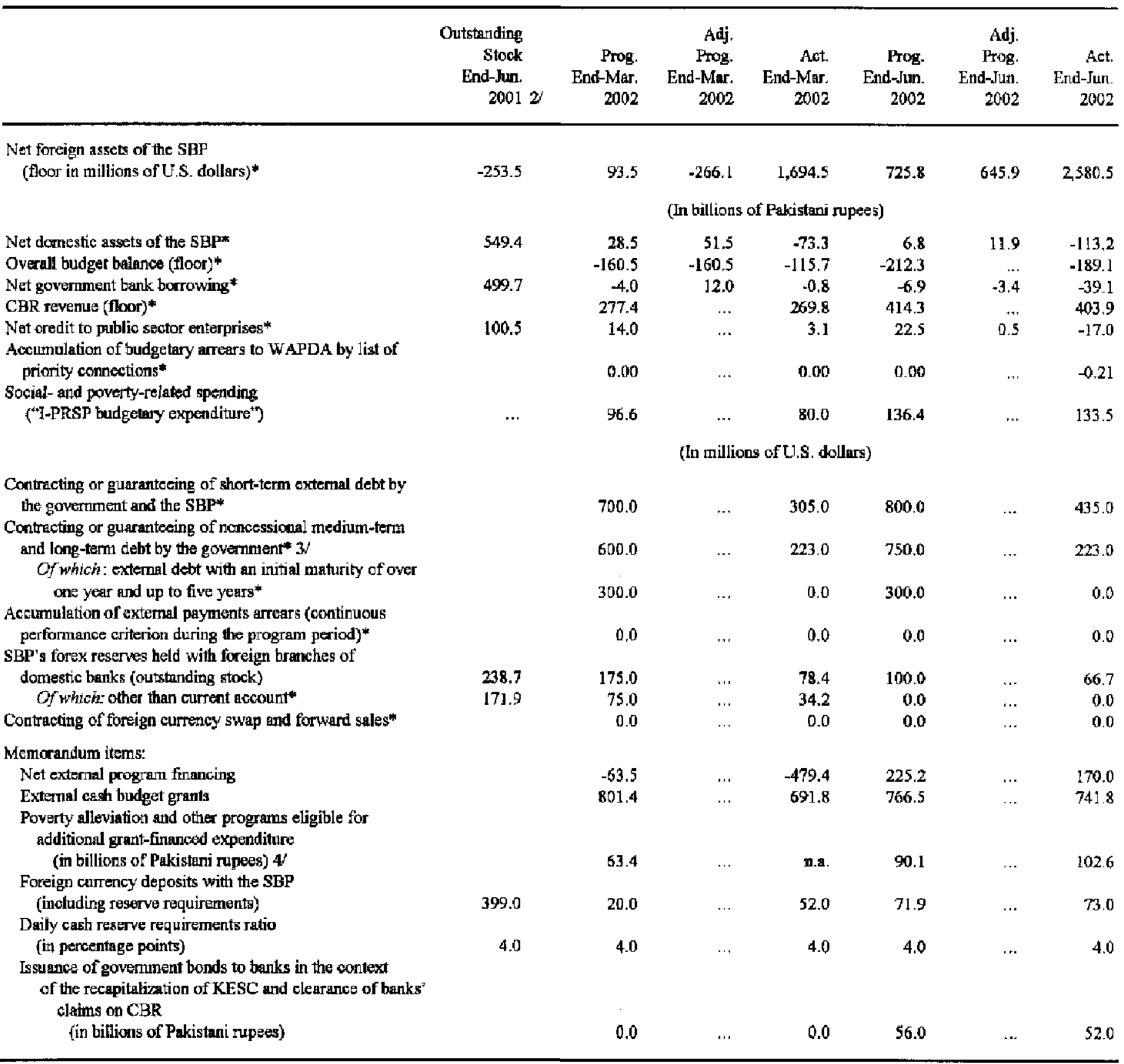

Source: Pakistani authorities.

1/ The relevant variables are defined in the Technical Memorandum of Understanding (TMU) dated November 2001 and the TMU dated March 12, 2002, and are subject to adjustors specified in the TMUs. For variables marked ${ }^{+\infty "}$ the end-December 2001, end-March 2002, and end-June 2002 program flows represent ceilings (or floor, if indicated) that constitute performance criteria. All other targets are indicative,

2 The June 200 I stock data and the December 2001 actual flow data for overall budget balance, net government bank borrowing, and net credit to public enterprises have been corrected for various date revisions. The revisions reletes to (a) the inclusion of the BSAL account and the Privatization Fund in SBP net claims on the government, (b) the reclassification of some bonds issued by public corporations, but serviced by the government, from net credit to public enterprises to net government bank borrowing, and (c) the reclassification of credit to privatized public enterprises from net credit to public enterprise to eredit to the private sector.

3/ Excluding PRGF loans.

4/ See definition it the TMU dated March 12, 2002, Table 2. 
Table 1(b). Pakistan: Quantitative Targets, September 2002-June 2003 1/

(Cumulative flows from July 1, 2002 unless otherwise specified)

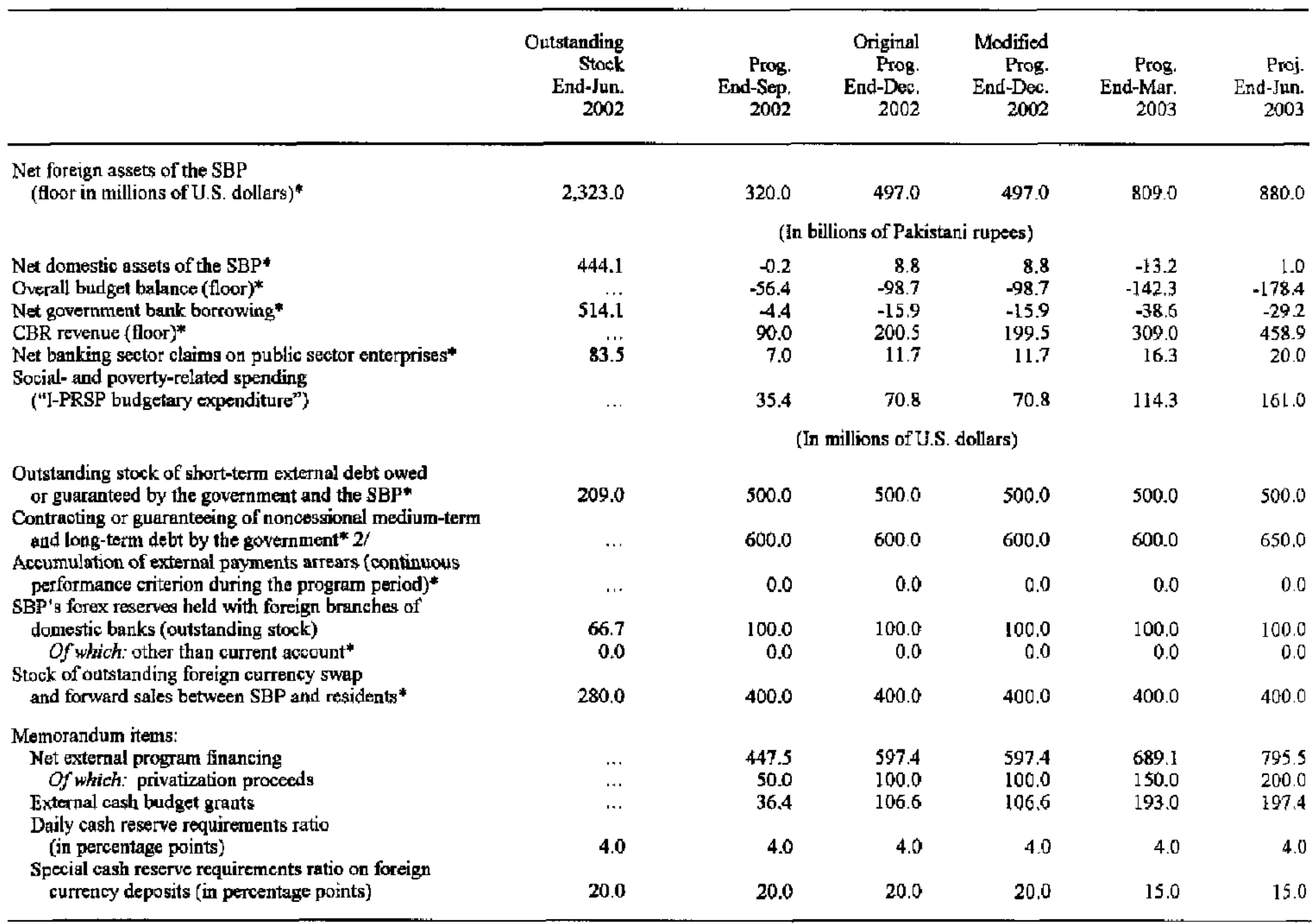

Source: Pakistani authorities.

1/ The relevant variables are defined in the Technical Memorandum of Understanding (TMU) dated June 2002 and are subject to adjustors specified in the TMU. For variables marked "** the end-September 2002, end-December 2002, and end-March 2003 program flows represent ceilings (or floor, if indicated) that constitute performance criteria. All other targets are indicative.

2/ Excluding PRGF loans. 
Table 2(a). Pakistan: Structural Performance Criteria and Benchmarks Under the PRGF Arrangement as set Under the Second Review 1/

\section{Structural Performance Criteria}

No new exemptions or special privileges regarding income tax, custom duties, or GST to be granted, no new regulatory import duties to be imposed (except for anti-dumping measures), and all time bound exemptions and regulatory import duties to lapse without extension, except for existing contracts and exemptions based on intemational commitments, and except for custom duty and income tax exemptions for the shipping industry (as described in the MEFP dated March 12, 2002, para. 20).

Implement new organizational setup for $C B R$ headquarters per approved CBR reform plan (as described in MEFP dated November 22, 2001, para. 21)

Apply standard GST penalty regime to retailers and eliminate GST exemptions for all fertilizer wholesale and retail trade.

Implementation of universal self-assessment effective for all income earned from July 1, 2002

Start operations of a Large Taxpayer Unit, integrating all domestic tax operations.

Implementation of income tax reform package effective for income earned from July 1, 2002 including: elimination of at least two minor withholding taxes; elimination of at least 55 income tax rebates, concessions, and nonstandard exemptions from the CRTTO-list; and lowering the threshold on NSS schemes subject to withholding tax on interest income from PRs 300,000 to PRs 150,000 .

Bring KESC to point of sale (as detailed in MEFP dated November 22, 2001, para. 23).
Continuous

February 28, 2002

Done.

March 31, 2002

July 1,2002

July 1,2002

July 1,2002

July 31,2002
Not met. All medicines were exempted from general sales tax on August 23, 2002.
Done.

Done (as new incoms tax ordinance came into force).

Done. Large Taxpayer Unit in Karachi started operations on July 1, 2002.

Done.

Not met. Expressions of interest invited in March 2002. Two investors expressed interest and one investor provided statement of qualificalion, which was accepted in June 2002. However, Investor has not yet started due diligence. Complementary reforms delayed due to legal complexities. 
Table 2(a). Pakistan: Structural Performance Criteria and Benchmarks Under the PRGF Arrangement as set Under the Second Review 1/

\section{Measures}

Timing

Angust 1, 2002

Issue circular allowing banks to purchase from August 1, 2002 foreign exchange from money changers at freely negotiated rates.

Issue budget call for FY 2003/04 budget on the basis of the New Accounting Model (NAM) for federal government and any one province, for parallel rum with existing system.

Publish quarterly progress reports on implementation of financial improvement plan of WAPDA/successors.
November 30,2002 for

the quarter July-

September 2002;

February 28, 2003 for

the quarter October-

December 2002.

\section{Structural Benchmarks}

Prepare list of intermediate indicators (selected from Table 5.3 and Tracking/Monitoring Matrix in Annex I of I-PRSP) with baseline data for 2000/01, and preliminary annual targets for the period FY 2001/02$2003 / 04$.

Quarterly published progress reports on implementation of Poverty Reduction Strategy, including "I-PRSP expenditure," as well as on progress in (a) establishing institutional framework for I-PRSP monitoring; (b) preparation of full PRSP; and (c) developing baseline data and monitoring framework for intermediate indicators.

Publish rules and regulations including for record-keeping under the universal self-assessment scheme for income tax to become effective July $1,2002$.

Prepare proposals for revised income and sales tax appeals and dispute resolution process with a view to implement them with the FY 2002/03 budget.
December 31, 2001

Done. List and annual targets included in the I-PRSP.

To start end-December 2001 for $2001 / 02 \mathrm{Q} 1$ data, and continued on the basis of the same quarterly schedule throughout FY 2001/02 and FY $2002 / 03$.

March 31, 2002

March 31, 2002
Done so far. Fourth report published in September 2002.
Status as of October 1,2002
Done. Foreign Exchange

Manual issued in January 2002 allows banks to purchase foreign exchange from money changers at freely negotiated rates.
Done. Draft rules published end-March 2002 to obtain public feedback. Final rules became effective July 1, 2002.

Done. New rules became effective July 1, 2002. 
Table 2(a). Pakistan: Structural Performance Criteria and Benchmarks Under the PRGF Arrangement as set Under the Second Review 1/

\section{Measures}

Timing
Status as of October 1, 2002
Bring United Bank Ltd. and PTCL to the point of sale through transparent and open public offer for sale.

Issuance of a streamlined foreign exchange manual to simplify and clarify rules regarding access to foreign exchange and current account transactions.

Establishment of a contributory pension scheme for new recruits in the civil service, and preparation of a third phase public pension reform package, prepared in collaboration with the World Bank and involving actuarially fair reform of early retirement and of commutation tables.

Implement structural electricity tariff adjustment consistent with WAPDA financial improvement plan.

Preparation of financial plans and quarterly performance targets for FY 2002/03 for PIA, Pakistan Railways, and Pakistan Steel Mills.

Eliminate administrative restrictions on the setting of interest rates on foreign currency deposits.

Implement revised sales tax and customs refund rules and procedures to reduce the incidence of incorrect claims and payments.

Prepare customs administration reform plan.

Make model income tax office for small and medium taxpayers in Lahore fully operational.

Amend SBP Act to strengthen central bank autonomy, in particular in the area of reserve management, per Safeguard Assessment recommendations.
May 31,2002

July 1,2002

July 1,2002

July 15,2002

August 31, 2002

September 30, 2002

September 30, 2002

September 30, 2002

October 31,2002

October 31, 2002
Delayed (for reasons explained in MEFP, para. 17); UBL was privatized in September 2002.

Done. Issued in January 2002.

Delayed. Actuarial cell in the Ministry of Finance to be established by end2002.

Delayed. Structural tariff increase of 9.2 percent on average became effective on August 13, 2002

Partially delayed. Financial plans prepared by end-August 2002 . Quarterly performance targets prepared on September 27, 2002

Done (SBP Circular No. 17 issued on July 9 , 2002).

Done.

Done. Plan was prepared by August 20,2002 .

Preparation on track.

Amendments approved by cabinet on Septernber 25, 2002; promulgation pending.

1/ Conditionality as of the Executive Board's conclusion of the second review under the PRGF arrangement (EBS/02/107). 
Table 2(b). Pakistan: Structural Performance Criteria and Benchmarks Under the PRGF Arrangement as Proposed for the Third Review

\section{Structural Performance Criteria}

No new (as per status of September 1, 2002) exemptions or special privileges regarding income tax, custom duties, or GST to be granted, no new regulatory import duties to be irmposed (except for antidumping measures), and all time bound exemptions and regulatory import duties to lapse without extension, except for existing contracts and exemptions based on international commitment.

Publish quarterly progress reports on implementation of financial improvement plan of WAPDA/successors.
Continuous

Met so far.
May 31, 2003 for the quarter January-March 2003.

\section{Prior Actions for Completion of Third Review}

Prepare financial improvement plan and quarterly performance targets for FY 2002/03 for KESC, based on approved multi-year tariff framework.

Effectiveness of multi-year electricity tariff framework for KESC to reduce regulatory uncertainty, providing for automatic adjustment to inflation and to fuel cost changes, and including immediate structural increase.

Plan was prepared, along with quarterly targets, on September 30, 2002 .

Implemented effective September 13, 2002 with average structural tariff increase of 6.5 percent.

Implement revenue measures to offset the exemption of medicines from GST in August 2002 and the lowering of petroleum taxation in September and early October 2002, to restore overall revenue for 2002/03 to program levels. 


\section{Amendments to the Technical Memorandum of Understanding (TMU)}

The TMU dated June 18, 2002 ("June-TMU") will remain valid for the remainder of FY 2002/03, with the revised baseline assumptions for net external program financing and external grants as indicated in Tables 1(a) and 1(b), and the following amendments to apply from January 1, 2003.

1. The second sentence of para. 6 of the June-TMU should be replaced by: "For the purposes of this memorandum, claims on government exclude credit for commodity operations; government deposits exclude outstanding balances in the Zakat Fund and balances in the various privatization accounts kept by the government in the banking system."

2. The first sentence in para. 8 of the June-TMU should be replaced by: "Net external budget financing is defined as net external program financing excluding privatization receipts (as recorded in the balance of payments) plus all other external loans for the financing of public projects or other federal or provincial budget expenditures, and plus external financing receipts transferred to the budget from the various privatization accounts."

3. Para. 16 of the June-TMU should be replaced by the following: "The ceilings on the NDA of the SBP will also be adjusted downward/upward by the amount of (a) banks' Pakistani rupee reserves freed/seized by any reduction/increase of the daily CRR relative to the baseline assumption; (b) banks' reserves freed/seized by any reduction/increase in the total reserve requirements on foreign currency deposits relative to the baseline assumption; and (c) any reduction/increase in the reservable deposit base that is related to definitional changes, as per the following formula: $\Delta \mathrm{NDA}=\Delta \mathrm{rB}_{0}+\mathrm{r}_{0} \Delta \mathrm{B}+\Delta \mathrm{r} \Delta \mathrm{B}$, where $\mathrm{r}_{0}$ denotes the reserve requirement ratio prior to any change; $B_{0}$ denotes the level of the reservable deposits in the initial definition; $\Delta r$ is the change in the reserve requirement ratio; and $\Delta B$ denotes the change in the reservable deposits as a result of definitional changes."

4. In para. 19, the following changes should be made:

First, the second bullet should be replaced by: "Deposits into and withdrawals from the privatization accounts for each quarter, within one month. Withdrawals will be reported with the following breakdown (a) those which constitute budgetary use of privatization proceeds; (b) those which constitute costs of privatization; and (c) other (with explanation of the purpose of other withdrawals)."

Second, items (ii) and (iii) in the $23^{\text {rd }}$ bullet in para. 19 should be replaced by:

(ii) Quarterly contracting or guaranteeing of nonconcessional medium- and long-term government debt; and

(iii) Information on any rescheduling on public- and publicly-guaranteed debt reached with creditors, within one month. 
Table1(b). Pakistan: External Grants for FY 2001/02 and FY 2002/03

(In millions of U.S. dollars)

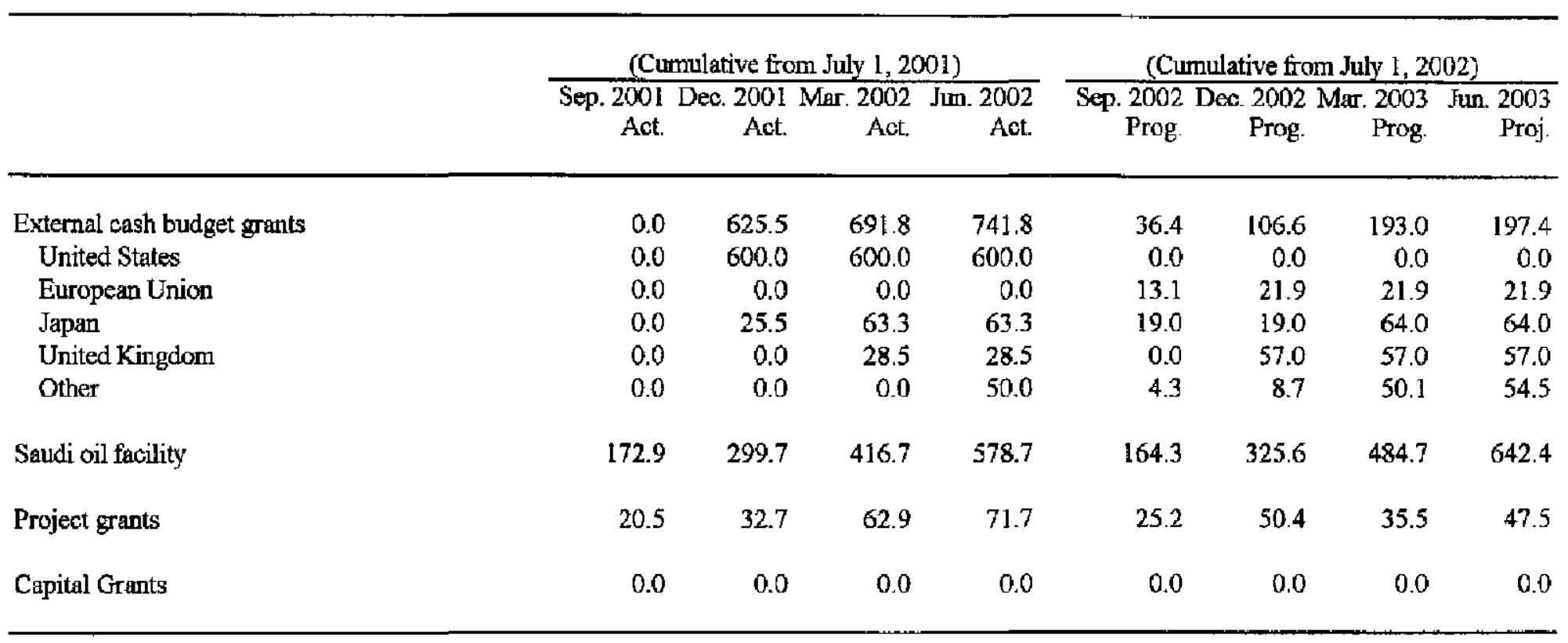


Table 1(a). Pakistan: Net External Program Financing FY 2001/02 and FY 2002/03

(In millions of U.S. dollars)

\begin{tabular}{|c|c|c|c|c|c|c|c|c|}
\hline & \multicolumn{4}{|c|}{ (Cumulative from July 1, 2001) } & \multicolumn{4}{|c|}{ (Cumulative from July 1,2002 ) } \\
\hline & $\begin{array}{r}\text { Sep. } 2001 \\
\text { Act. }\end{array}$ & $\begin{array}{r}\text { Dec. } 2001 \\
\text { Act. }\end{array}$ & $\begin{array}{r}\text { Aar. } 2002 \\
\text { Act. }\end{array}$ & $\begin{array}{r}\text { Jun. } 2002 \\
\text { Act. }\end{array}$ & $\begin{array}{c}\text { Sep. } 2002 \\
\text { Prog. }\end{array}$ & $\begin{array}{l}\text { Dec. } 2002 \\
\text { Prog. }\end{array}$ & $\begin{array}{l}\text { Aar. } 2003 \\
\text { Prog. }\end{array}$ & $\begin{array}{l}\text { Jun. } 2003 \\
\text { Proj. }\end{array}$ \\
\hline Program financing $(a+b+c+d+e+f-g+h)$ & -160.5 & -180.2 & -479.4 & 170.0 & 447.5 & 597.4 & 689.1 & 795.5 \\
\hline (a) World Bank & 0.0 & 95.0 & 95.0 & 697.5 & 185.0 & 215.0 & 400.0 & 550.0 \\
\hline (b) AsDB loans & 0.0 & 150.0 & 150.0 & 185.0 & 235.0 & 385,0 & 455.0 & 455.0 \\
\hline (c) Other multilaterals & 0.0 & 0.0 & 0.0 & 0.0 & 0.0 & 0.0 & 0.0 & 0.0 \\
\hline (d) Bilateral loans & 0.0 & 0.0 & 0.0 & 0.0 & 0.0 & 0.0 & 0.0 & 0.0 \\
\hline (e) Commercial bank borrowing & 207.0 & 469.0 & 660.3 & 822.7 & 100.0 & 200.0 & 300.0 & 400.0 \\
\hline Of which: IDB & 106.0 & 176.0 & 267.3 & 329.7 & 100.0 & 200.0 & 300.0 & 400.0 \\
\hline (f) Privatization receipts & 0.0 & 0.0 & 0.0 & 117,0 & 50.0 & 100.0 & 150.0 & 200.0 \\
\hline (g) Amortization due & 650.3 & $1,392.7$ & $2,155.0$ & $2,861.7$ & 393.0 & 790.9 & $1,346.2$ & $1,734,0$ \\
\hline Multilateral creditors & 122.4 & 258.4 & 376.2 & 499.2 & 130.7 & 270.6 & 400.6 & 526.1 \\
\hline Bilateral creditors & 193.6 & 324.5 & 484.2 & 646.9 & 184.9 & 302.0 & 467.3 & 567.9 \\
\hline Commercial creditors & 317.9 & 772.2 & $1,236.4$ & $1,633,0$ & 49.5 & 169.7 & 397.7 & 538.1 \\
\hline Other (Military) & 16.4 & 37.6 & 58.2 & 82.6 & 27.9 & 48.6 & 80.6 & 101.9 \\
\hline (h) Debt service rescheduled/arrears & 282.8 & 498.5 & 770.3 & $1,209.5$ & 270.5 & 488.3 & 730.3 & 924.5 \\
\hline Multilateral creditors & 0.0 & 0.0 & 0.0 & 0.0 & 0.0 & 0.0 & 0.0 & 0.0 \\
\hline Bilateral creditors & 267.6 & 460.4 & 717.4 & $1,127.9$ & 245.9 & 440.3 & 656.6 & 827.4 \\
\hline Commercial creditors & 0.0 & 0.0 & 0.0 & 0.0 & 0.0 & 0.0 & 0.0 & 0.0 \\
\hline Other (Military) & 15.2 & 38.1 & 52.9 & 81.6 & 24.6 & 48.0 & 73.7 & 97.1 \\
\hline
\end{tabular}




\section{REPORT ON THE OBSERVANCE OF STANDARDS AND CODES Fiscal Transparency and Data Modules PAKISTAN-A NOTE ON RECENT DEVELOPMENTS AUGUST 2002}

1. The 2002 Article IV mission to Pakistan has compiled information on developments following the publication of the recent ROSC module. The descriptions and assessment in that module remain valid with the modification noted below. The ROSC module is:

Pakistan: Report on the Observance of Standards and Codes-Fiscal Transparency Module (http://www.imf.org/external/np/rosc/pak/index.htm).

2. The authorities are implementing the recommendations of the fiscal ROSC module. In particular, they have focused on strengthening the core fiscal reporting system, as indicated further below. Efforts to develop a medium-term budget framework (including costing of programs) are being initiated as part of the preparation of the full the Poverty Reduction Strategy Paper.

3. Fiscal Monitoring Committees (FMCs) have been established at the federal and provincial level. The FMCs coordinate and monitor fiscal reporting and promote measures to improve reconciliation of accounts and the quality of fiscal data. The federal FMC takes the lead and coordinates with the provincial FMCs. The federal FMC publishes a quarterly report on the status of reconciliation of accounts. Public Accounts Committees (PACs) have been re-established under executive order.

4. Reconciliation of accounts at the federal and provincial level has greatly improved. Improved quality of accounting data is being tackled on a number of fronts. At the federal level virtually full reconciliation has been achieved between departmental spending and receipts records and the Accountant General Pakistan Revenue (AGPR) accounts (albeit with some continuing problems for complete reconciliation with the Central Board of Revenue). On foreign financed projects, monthly reconciliation occurs between the Economic Affairs Division records and AGPR and an explanation is given for all differences, but full recording of foreign financed project receipts by the SBP has yet to be achieved. Bank reconciliation procedures at the district level are being vigorously pursued. Progress has been more mixed at the provincial level, with good progress being recorded in Sindh and North West Frontier provinces, but a number of continuing problems in Punjab. Decentralization of fiscal management will require continuing vigilance to ensure that adequate accounting and reporting standards are maintained, in particular regarding further reduction of the use of personal ledger accounts and equivalent practices.

5. The functions of auditing and accounting have been separated with the transfer of the Controller General of Accounts (CGA) office to the executive branch of government. The CGA office has authority, under its ordinance, over preparation and 
maintenance of accounts at the federal, provincial, and district levels of government, although the extent of authority over subnational accounting staff is subject to continuing debate. The CGA's tasks include establishing a unified reporting system at all levels of government, implementing the Pakistan Improvement of Financial Reporting and Audit (PIFRA) project, and maintaining and developing accounting standards at all levels of government.

6. The Ministry of Finance has started to publish quarterly fiscal reports on its website (http://www.finance.gov.pk/pak fis/main.htm). Monthly reports for the federal government are expected to be published on the website in the near future. A report on contingent liabilities and tax expenditures is included in the Economic Survey (http:/www.finance.gov.pk/survey/main.html) which is published a few days before the budget is presented. The budget itself does not discuss contingent liabilities or tax expenditures.

7. A new income tax ordinance has become effective as of July 1,2002 . The new income tax law is based on universal self-assessment and global income. Rules for mandatory record-keeping have been issued. Audit selection will be determined through a parameter-based risk analysis. The first returns based on the new law will be filed in September 2003 for the tax-year 2002/03. With the 2002/03 budget, a significant number of tax exemptions have been eliminated.

8. The authorities have prepared a draft fiscal responsibility law. The draft law was published on the Ministry of Finance website for comments by the public (http://www.finance.gov.pk/law/back ground.pdf; http://www.finance.gov.pk/law/frdlo.pdf). 


\section{Statement by the IMF Staff Representative November 1, 2002}

1. This statement summarizes the information that has become available since the staff report (EBS/02/182) was circulated to the Executive Board on October 21, 2002. It does not change the thrust of the staff appraisal.

\section{Prior actions}

2. The information provided by the authorities indicates that all the prior actions listed in the October 16, 2002 Memorandum of Economic and Financial Policies have been taken.

3. A multi-year electricity tariff framework for KESC was implemented effective September 13, 2002 to reduce regulatory uncertainty. It provides for automatic adjustment of tariffs to inflation and fuel cost changes, and includes an immediate structural increase of 6.5 percent.

4. A financial improvement plan (FIP) with quarterly performance targets for FY 2002/03 for KESC, based on the approved multi-year tariff framework, was finalized on September 30, 2002. So far, only one large foreign company continues to indicate interest in $\mathrm{KESC}$, and is expected to initiate due diligence once a new government is formed and its economic strategy becomes visible.

5. On October 31,2002 , the authorities notified an increase in petroleum levies by a weighted average of 12.1 percent to become effective November 1, 2002, following an increase of 15.3 percent on October 15,2002. As a result, as of November 1, 2002 the average petroleum levy will stand at PRs 4.28 per liter, compared with PRs 3.97 per liter on July 1,2002 . This action restores the basis for the overall revenue targets under the program, and more specifically offsets the revenue losses from the exemption of medicines from GST in August 2002 and the lowering of petroleum taxation in September and early October 2002 (to a low of PRs 3.31 per liter).

\section{Progress towards the October 31, 2002 structural performance criterion and benchmarks}

6. The authorities have informed staff that the following step toward structural performance criteria and benchmarks for end-October were taken:

7. On October 30, 2002 the budget call for the 2003/04 federal budget was issued on the basis of the New Accounting Model (NAM), and on October 31, 2002, according to information yet to be confirmed, the North Western Frontier province issued its budget call, using NAM in parallel with the conventional format.

8. The model tax unit for small and medium taxpayers in Lahore has started operations in late October 2002. Similarly to the large taxpayer unit opened in Karachi in July 2002, it involves steps towards administering all domestic taxes in a functionally integrated manner. 
9. Amendments to the SBP Act, aimed at strengthening central bank autonomy, in particular in the area of reserve management in line with the Safeguard Assessment recommendations, were approved by cabinet on September 25, 2002 and promulgated on October 31, 2002.

\section{Recent developments}

10. General elections on October 10,2002 ushered in the return to civilian government. No political party emerged from the elections with a majority of seats in the (federal) National Assembly. Talks between the main parties to form a coalition government are underway. Large military forces are still deployed along the border with India, but both India and Pakistan recently announced a partial withdrawal of troops.

11. Little additional information on macroeconomic developments has become available since the staff report was issued. The rate of inflation as measured by the CPI remained unchanged in September, with a 12-month increase of 3.7 percent. September data confirmed the pickup in trade flows observed since last spring. In July-September 2002, exports and imports in dollar terms were higher than in July-September 2001 by, respectively, 14.0 percent and 11.1 percent. Remittances remained strong during the summer, reaching about US\$1.1 billion in July-September 2002, about three times as high as a year ago. This, as well as large disbursements from bilateral and multilateral donors, have allowed the SBP to build official reserves much faster than expected to US $\$ 6.3$ billion as of end-October 2002, equivalent to about five months of next year's imports of goods and nonfactor services. The Pakistani rupee slightly appreciated against the U.S. dollar. The main stock market index further rose in the past weeks (by about 15 percent between end-August and end-October).

12. Broad money growth remained strong, with a 12-month increase of about 15 percent in August, similar to June and July. While net foreign assets of the banking system continued to grow at a rapid pace, net domestic assets decreased on account of a seasonal contraction of credit to the economy. Interest rates remained stable in recent months, with the yield on six-month treasury bills at about 6.5 percent.

13. The CBR met its revenue target for end-September 2002, reflecting a relatively buoyant economy, strong imports, and high oil prices. Other available data on federal revenue and expenditure for the first quarter of $2002 / 03$ indicate that the authorities were on track to meet the end-September fiscal objectives.

14. In September 2002, the authorities - in consultation with the World Bank and the U.K. Department For International Development-identified intermediate indicators for health and education designed to monitor progress towards the I-PRSP targets. The indicators rely largely on data produced in-house by the respective ministries. In addition, the World Bank's Core Welfare Indicators Questionnaire would be adapted to Pakistan; the Pakistan Integrated Household Survey would be consulted for some background information. In the education sector, the indicators focus on school facilities as well as availability and quality of 
teachers. In the health sector, the indicators focus on availability of basic health services and immunization.

15. The subscription for the second offering of 5 percent government shares in National Bank of Pakistan (NBP) to the general public was opened from October 7, 2002 to October 9, 2002. It was oversubscribed by four times.

16. As of late October 2002, bilateral agreements implementing the December 2001 Agreed Minute with Paris Club creditors had been signed with Austria, Canada (Export Development Corporation and Canadian Wheat Board), Finland, Spain, and the United States. 
Public Information Notice (PIN) No. 02/128

FOR IMMEDIATE RELEASE

November 6, 2002
International Monetary Fund

$70019^{\text {th }}$ Street, NW

Washington, D. C. 20431 USA

\section{IMF Concludes 2002 Article IV Consultation with Pakistan}

On November 1, 2002, the Executive Board of the International Monetary Fund (IMF) concluded the 2002 Article IV consultation with Pakistan. ${ }^{1}$

\section{Background}

Pakistan entered the 21 st century with both high poverty rates and severe macroeconomic imbalances. Several attempts at bringing the economy on a path of declining public debt in the 1990 s failed due to repeated policy slippages, resulting in growing macroeconomic instability and external vulnerability. The government, in office since October 1999, therefore put at the heart of its initial economic strategy a program of macroeconomic adjustment. Following the successful completion of a stabilization program supported by an IMF Stand-By Arrangement, a medium-term reform strategy was set forth in Pakistan's interim Poverty Reduction Strategy Paper that explicitly acknowledged that progress was needed on a broader front for several reasons to: (a) improve the investment climate in the country; (b) reduce the economy's vulnerability to external or internal shocks; and (c) put the economy on a sustainable growth path, and ensure that growth translates into palpable improvements in living standards for the population at large, and the poor in particular. The policy package to achieve these

\footnotetext{
' Under Article IV of the IMF's Articles of Agreement, the IMF holds bilateral discussions with members, usually every year. A staff team visits the country, collects economic and financial information, and discusses with officials the country's econornic developments and policies. On return to headquarters, the staft prepares a report, which forms the basis for discussion by the Executive Board. At the conclusion of the discussion, the Managing Director, as Chairman of the Board, summarizes the views of Executive Directors, and this summary is transmitted to the country's authorities. This PIN summarizes the views of the Executive Board as expressed during the November 1, 2002 Executive Board discussion based on the staff report.
} 
objectives centered on fiscal adjustment to bring debt to sustainable levels while raising social- and poverty-related expenditure, and a wide range of governance reforms to stimulate private sector growth and improve social service delivery.

In the past two years, considerable progress was made in implementing this agenda, even while Pakistan's economy was exposed to several negative shocks. A slowdown in the world economy, high oil prices, protracted drought, trade disruption in the wake of September 11, and regional and domestic security problems have increased uncertainty for business and hampered growth. Despite this unfavorable context, real GDP at factor costs grew by 3.6 percent in FY $2001 / 02$ (ending in June 2002). Due to a large increase in worker remittances, real GNP growth was significantly higher. Average inflation in 2001/02 was 2.7 percent, one of the lowest in Pakistan's history. However, inflation picked up in the first half of 2002, to 3.7 percent in the year through August 2002.

The external accounts recorded a dramatic turnaround and reserves were built up to levels unprecedented in Pakistan's history. The current account excluding grants recorded a small surplus in 2001/02 on account of an improved trade balance and the surge in worker remittances. Combined with a substantial net exceptional financing in the form of debt rescheduling and program financing from international financial institutions, this allowed the State Bank of Pakistan (SBP) to build up foreign exchange reserves in the course of the year much faster than expected. At end-June 2002, gross official reserves stood at US $\$ 4.3$ billion, equivalent to 17.5 weeks of next year's imports of goods and nonfactor services, compared with US\$1 billion at end-2000; by endSeptember 2002 reserves had risen to US\$5.9 billion. Since late 2001, the Pakistani rupee has remained virtually stable against the U.S. dollar, with large foreign exchange purchases by the SBP, exclusively in the interbank market since June 2002.

Though revenue collection has been repeatedly below program targets, the overall fiscal situation improved in 2001/02. The budget deficit including grants decreased from 5.5 percent of GDP in 1999/2000 to 4.2 percent of GDP last fiscal year, despite sizable exceptional expenditures in 2001/02, such as the recapitalization of the Karachi Electric Supply Corporation (KESC) and the settlement of excess taxes paid by banks. Socialand poverty-related expenditure picked up significantly in the second half of the year, once the initial administrative problems of the newly elected local governments were overcome, and were only marginally lower than the target under the I-PRSP.

Broad money increased strongly in 2001/02. Though the SBP was successful at containing reserve money growth within program limits, owing to an aggressive sterilization of its foreign exchange purchases, the banking system's net domestic assets recorded a slight increase partly on account of a moderate rise in credit to the private sector. As a consequence, the very large accumulation of net foreign assets by the banking system led to an almost 16 percent annual increase in broad money at endJune 2002 . Interest rates have remained relatively stable since early 2002 , with the yield on six-month treasury bills hovering around 6.5 percent after a sharp decrease in 2001.

The authorities' comprehensive structural reform agenda, focusing on improved govemance, was steadfastly implemented in the past two years. Progress has been 
made in particular in tax policy and tax administration reform, fiscal accountability and transparency, trade reform, energy pricing, privatization, and financial sector restructuring. Reform of social service delivery is also underway, with an ambitious devolution plan aimed at empowering the population at the grassroots level. In the wake of September 11, the privatization program has experienced delays for the more difficult cases (notably KESC), largely reflecting the difficulties in global equity markets and security concerns.

\section{Executive Board Assessment}

Executive Directors noted that despite various adverse shocks, which took a toll on economic activity, Pakistan has succeeded in consolidating macroeconomic stability over the past two years. Growth appears to be picking up, inflation remains subdued, and the external accounts have strengthened considerably owing to high worker remittances, sizable capital inflows, and, more recently, improved export performance. The strong external position has allowed the central bank to build official reserves to unprecedented levels, reducing its vulnerability to external shocks. Structural reforms have focused on tax policy and administration, energy pricing, privatization, fiscal accountabiity, transparency, and governance. Directors were encouraged that the fiscal deficit has declined and social sector spending is increasing as local governments have become operational. The Central Board of Revenue (CBR) revenue shortfall through June 2002 is, however, regrettable and calls for a decisive effort to reinforce revenue collection.

Notwithstanding these overall favorable developments, Directors observed that the high public debt burden continues to constrain needed investments in human development and infrastructure, and that private investment and economic growth remain insufficient to reduce rapidly Pakistan's high rate of poverty. The key policy challenges for the medium term are therefore to improve the public debt dynamics further through fiscal adjustment, and to address Pakistan's "social gap" through enhanced provision of basic social services. Directors stressed that progress on these fronts will critically depend on stronger tax collection efforts and improved financial performance of public enterprises, especially the utility comparies. They urged the authorities to step up the allocation of resources to basic education and health as well as to ensure the efficient use of these resources, which will be key to improving productivity and growth prospects. Ongoing steps to improve the monitoring of social spending were welcomed.

Directors viewed Pakistan's near-term economic outlook as broadly encouraging, with recent data confirming a continued recovery in exports, imports, and tax revenue. At the same time, however, downside risks remain, including the risk that the reform efforts will not be sustained over a sufficiently long period of time, or that the current reforms will take longer than assumed to produce a strong impact. Directors drew comfort from the improved resilience of Pakistan's debt dynamics to various shocks, provided recent reforms are not reversed, and from the authorities' demonstrated ability to hold the program broadly on course in a difficult environment. Building on this, they stressed that the central task for the new government will be to deal resolutely with the remaining 
challenges, while further broadening and deepening the ownership of the reform effort in the period ahead. Important, in this regard, will be continued strong efforts to explain the rationale for reform to the population, and further sustained improvements in governance and the delivery of social services.

Directors considered the proposed macroeconomic policy mix for the near future to be appropriate. Monetary policy will be geared toward keeping inflation low, within the current flexible exchange rate system, and continued fiscal adjustment will aim at further improving public debt dynamics. Monetary and price developments will nevertheless need to be kept under close watch, and the authorities should be ready to consider a moderate tightening of monetary policy if needed. Most Directors saw merit in continued sterilized intervention to contain the real appreciation of the Pakistani rupee in the face of continuous strong capital inflows. Some Directors, however, cautioned that this is unlikely to be a solution over the longer term, and that competition-enhancing structural measures are a more effective approach to deal with upward pressures on the external value of the currency.

Directors supported the further reduction of the budget deficit planned for next year. Noting that the budgetary position remains vulnerable and subject to regional tensions, they urged the authorities to ensure the attainment of the revenue objectives and to keep tight control over expenditure, while protecting social and poverty-related spending. In this regard, Directors highlighted, in particular, the need for carefully following through on CBR reforms, and several Directors suggested to explore the feasibility of more ambitious revenue plans going forward. A number of Directors also urged the authorities to continue exploring the possibility for savings on defense expenditures.

Directors welcomed the focus of the structural reform agenda on improved governance across a broad range of areas, and strongly supported the continuation of these efforts to improve conditions for private sector development and growth. They emphasized that delays or loss of momentum in implementing the reform agenda would work at crosspurposes with the aim of reducing poverty. Directors welcomed the publication of a draft fiscal responsibility and debt reduction ordinance for public comment, and encouraged the authorities to consider further simplifying its specifications and extending its application to provinces and local governments. They supported the ongoing reforms in the financial sector, including the planned reduction in government ownership in the banking industry and the closer alignment of National Savings Scheme instruments with market conditions. Directors encouraged the authorities to continue working closely with Pakistan's development partners to address the remaining weaknesses in the financial sector, including further strengthening of the regulatory environment and the resolution of nonperforming loans. They looked forward to the smooth development of Islamic banking alongside conventional banking, and passage of anti-money laundering legislation in line with international standards, and were hopeful that an Financial Sector Assessment Program could scon be conducted.

Directors commended the recent efforts to restructure public enterprises, but noted that a considerable agenda remains. They urged the authorities to accelerate the reform of 
the two power utilities to contain their drain on the budget, and in particular, to ensure timeiy tariff adjustments and step up efforts to improve receivables collection. While welcoming steps to make major public enterprises more accountable to the public, Directors underscored the importance of accelerating privatization, especially in the power and telecoms sectors.

Directors expressed reservation about plans to support the restructuring and/or investment programs of various public enterprises with "one-off" budgetary transfers. They cautioned that such plans should be part of a clearly articulated strategy to restructure, privatize, or liquidate them, and that their cost should be part of the budget process rather than being brought up in an ad hoc fashion after the budget was passed.

Directors welcomed the authorities' efforts to improve the quality, timeliness, and reporting of data. They looked forward to further steps to address remaining weaknesses that hamper the analysis of economic and financial market developments, and to Pakistan's participation in the General Data Dissemination System.

Public Information Notices (PINs) are issued, (i) at the request of a member country, following the conclusion of the Article IV consultation for countries seeking to make known the views of the IMF to the public. This action is intended to strengthen IMF surveillance over the economic policies of member countries by increasing the transparency of the IMF's assessment of these policies; and (ii) following policy discussions in the Executive Bcard at the decision of the Board. 
Pakistan: Selected Economic Indicators 1/

\begin{tabular}{lcccr}
\hline & $1998 / 99$ & $1999 / 2000$ & $2000 / 01$ & $2001 / 02$ \\
\hline $\begin{array}{l}\text { Real GDP growth (factor } \\
\text { cost, percentage change) }\end{array}$ & 4.2 & 3.9 & 2.5 & 3.6 \\
$\begin{array}{l}\text { CPI inflation (period } \\
\text { average, percentage } \\
\text { change) }\end{array}$ & 5.7 & 3.6 & 4.4 & 2.7 \\
$\begin{array}{l}\text { Overall balance } \\
\text { (including grants, } \\
\text { percent of GDP) }\end{array}$ & & & & \\
$\begin{array}{l}\text { Net public dobt (in } \\
\text { percent of GDP) }\end{array}$ & -6.0 & -5.5 & -4.1 & -4.2 \\
$\begin{array}{l}\text { Broad money growth } \\
\text { (percentage change) }\end{array}$ & 88.6 & 86.6 & 103.8 & 96.2 \\
$\begin{array}{l}\text { Current account balance } \\
\text { (including official } \\
\text { transfers, percent of } \\
\text { GDP) }\end{array}$ & 6.2 & 9.4 & 9.0 & 15.2 \\
$\begin{array}{l}\text { Grass International } \\
\text { reserves } \\
\text { (millions of U. S. doliars) }\end{array}$ & 17.0 & 3.0 & 12.8 & 5.2 \\
$\begin{array}{l}\text { Pakistan rupees per U.S. } \\
\text { dollar (period averag日, } \\
\text { percentage change) }\end{array}$ & -3.6 & -2.0 & -1.9 & 2.5 \\
\hline
\end{tabular}

Sources: Data provided by Pakistani authorities, and IMF staff. 1/ Pakistan's fiscal year runs from July 1 to June 30 . 




FOR IMMEDIATE RELEASE

News Brief No. 02/110

FOR IMMEDIATE RELEASE

November 1, 2002
International Monetary Fund

700 19th Street, NW

Washington, D. C. 20431 USA

\section{IMF Completes Third Review of Pakistan's PRGF-Supported Program, Approves US\$114 Million Disbursement}

The Executive Board of the International Monetary Fund (IMF) completed today the third review of Pakistan's performance under a three-year, SDR 1.03 billion (about US $\$ 1.4$ billion) Poverty Reduction and Growth Facility arrangement (see Press Release No. 01/51). The completion of this review enables the release of a further SDR 86 million (about US $\$ 114$ million) to Pakistan, which will bring total disbursements under the IMFsupported program to SDR 345.64 million (about US $\$ 456$ million).

In approving the disbursement, the Executive Board granted waivers that addressed Pakistan's non-observance of its quarterly Central Board of Revenue (CBR) revenue target for the period ended June 30, 2002; the absence of bringing the Karachi Electric Supply Corp. to the point of sale by end-July 2002; and for granting new tax exemptions in the review period.

The Poverty Reduction and Growth Facility (PRGF) is the IMF's concessional faclity for low-income countries. PRGF-supported programs are based on country-owned poverty reduction strategies adopted in a participatory process involving civil society and development partners, and articulated in a Poverty Reduction Strategy Paper (PRSP). This is intended to ensure that each PRGF-supported program is consistent with a comprehensive framework for macroeconomic, structural, and social policies, to foster growth and reduce poverty. PRGF loans carry an annual interest rate of 0.5 percent, and are repayable over 10 years with a $5 \frac{1}{2}$ year grace period on principal payments. 
Following the Executive Board's review of Pakistan, Eduardo Aninat, Deputy Managing Director and Acting Chair, said:

"The Fund commends the authorities for further consolidating gains in macroeconomic stability and progressing with structural reforms in a difficult e conomic and political environment. E conomic a ctivity is picking up, inflation remains low, and strong private capital inflows and remittances have contributed to a strong building up of official reserves. The fiscal deficit for end-June 2002 was lower than programmed, even though tax revenue collected by the Central Board of Revenue (CBR) regrettably fell again short of target. Encouragingly, the pace of social sector spending is reported to have accelerated and is in line with the program target for the year.

"The reform package for FY 2002/03, centered on further consolidation of macroeconomic stability and on structural reforms aimed at strengthening tax revenue, public expenditure management, and governance in a wide range of areas, remains broadly on track. Assuming an effective implementation, and in the absence of any major exogenous shocks, real GDP is projected to grow by 4.5 percent, which should help reduce the high poverty levels. The envisaged mix of cautious monetary and flexible exchange rate policies and continued fiscal consolidation should help keep inflation low and allow for a further reduction of the public debt burden. Preliminary data indicate that during the quarter to September, exports and imports recovered strongly, and that the CBR revenue target for the quarter was met.

"A continued fiscal effort will be key to reducing public debt further while increasing funding for Pakistan's public social s ervices. This will require strong enforcement of tax collection, a determined reduction of the drain from loss-making public enterprises on the budget, and a better monitoring of social service delivery to ensure efficient use of available resources. In view of the risks to the economic outlook, the authorities need to stand ready to undertake appropriate corrective fiscal measures if needed to achieve the budgetary targets.

"Forceful implementation of the restructuring strategy for the two power utilities, the Water and Power Development Authority (WAPDA) and Karachi Electric Supply Corporation (KESC), is essential for putting an end to their persistent drain on budgetary resources and providing Pakistan's economy with reliable power at competitive prices. The focus of the reforms $n$ eeds to be on reducing leakage, fraud, a nd a dministrative costs, and better enforcing bill collections as set out in each utility's 
financial improvement plan. Privatization of KESC and of certain components of WAPDA wil! be critical to achieve the targeted efficiency gains," Mr. Aninat stated. 
Key points

- Economic performance, since the last review, has been encouraging amid signs that the economy is moving onto a higher growth path;

- The 2002/03 program will focus on stability-oriented macroeconomic policies, enhancing the effectiveness of I-PRSP expenditures and addressing the ambitious public enterprise, governance, and privatization agenda;

- The authorities envisage a substantial further acceleration in I-PRSP expenditures so as to make inroads into reducing Pakistan's "social gap." New mechanisms to monitor intermediate poverty indicators should be in place shortly;

- Public reporting of, and accountability for, implementation of financial improvement plans should create constructive pressure on all major public enterprises to perform as promised;

- The privatization of the United Bank Limited has been successfully concluded and the process of divestiture in the oil and gas sector is expected to proceed as planned. Other important reforms have been undertaken in the financial sector;

- The new government will inherit an economy poised for accelerated growth. The authorities are confident that the new government will seize the opportunity to press ahead with the reform agenda.

My Pakistan authorities are grateful to staff for an excellent report and background papers, their hard work, and a fruitful round of discussions, which, together with the Article IV consultation, provided an opportunity to reflect on, and draw lessons from, the adjustment experience of the past few years. I am pleased to report that the remaining prior action regarding revenue measures was taken on October 29, 2002, and became effective on October 31, 2002. I thank Executive Directors for their understanding in allowing the Board discussions to proceed as scheduled.

Economic developments in Pakistan, since the last review in July 2002, have been marked by continued macroeconomic discipline and steady progress in structural reform despite the challenges posed by the prolongation of the drought, the difficult regional security situation, the weak global economy, and high oil prices. Indeed, there are recent welcome indications that the economy is beginning to make the transition onto a higher growth path. At the same 
time, inflation remains well under control and the external account has remained strong, supported by a surge in workers' remittances and private capital flows, which has helped build reserves to unprecedented levels. This broadly positive macroeconomic picture is being underpinned by tangible progress on the structural front, most notably in the areas of tax administration, energy pricing, privatization, and fiscal accountability, and a sharp increase in social sector spending. Overall, the authorities are pleased with what has been accomplished in the past two years under difficult circumstances. Nevertheless, they realize that significant challenges remain, namely, continued low levels of growth, private investment and employment creation, inadequate provision of basic social services, and little evidence of a decline in poverty.

The authorities recognize that the policies and reforms implemented in recent years will only have a lasting impact in terms of improving the lives of the people if continued over the medium term. In this context, staff note that the "main danger" to the program lies in the possibility that the reform effort would not be sustained over a sufficiently long period. Specifically, there are questions whether the new democratically elected government, which is to take office shortly, will challenge the economic strategy and reform agenda. At a delicate time of political transition, these are legitimate questions. However, despite misgivings in some quarters and an understandable impatience to see early results in terms of benefits reaching the people, the authorities are assured that there is sufficient support across a broad spectrum of the political landscape for the government's policies. This is reinforced by a growing and widespread realization that staying the course offers the best hope of rekindling durable growth and alleviating poverty. If anything, the newly elected government offers "an opportunity to anchor reforms in a broader political consensus" and thereby strengthen ownership.

The thrust of the 2002/03 program is directed towards continuation of stability-oriented macroeconomic policies, enhancing the effectiveness of poverty-related expenditures, and forcefully addressing the ambitious public enterprise reform, governance, and privatization agenda. Economic growth is projected to accelerate to 4.5 percent led by exports; inflation is expected to remain subdued; and the external position should remain robust with gross reserves rising to about five months of imports. Monetary policy will continue to be vigilant, given the uncertainties about money demand, and will guard against a possible re-emergence of inflationary pressures. The recent appreciation of the rupee notwithstanding, there is no evidence that the exchange rate is misaligned; competitiveness remains adequate and should help foster the on-going diversification of the export base.

The path of fiscal consolidation is fully in line with the original financial program. CBR revenues - which have consistently fallen short of expectation in the past-are now showing signs of buoyancy in the context of the pickup in real sector activity, and preliminary data suggest that the end-September performance criterion was met. CBR reforms are also on track and a new strategy to reform customs administration has been sent to Fund staff for comments. On the expenditure side, there have been significant changes in the composition of expenditures to meet the urgent requirements associated with the restructuring of key public enterprises. The authorities expect that these new expenditures will help public enterprises strengthen their financial position, reduce their claims on the budget, and will 
pave the way for future privatization. Building on the acceleration of I-PRSP expenditure towards the end of last year, as the newly elected local governments became operational, the budget envisages a further substantial increase in these expenditures aimed at making inroads into reducing Pakistan's "social gap." Concurrently, with assistance from the World Bank and the U.K. Department for International Development, the authorities hope to have new mechanisms to monitor intermediate poverty indicators in place by the end of the year, which will be closely tracked by the recently established I-PRSP Secretariat.

The program entails a strong commitment to move forward with reforming the major public enterprises, while improving monitoring and accountability. Public reporting of, and accountability for, implementation of the financial improvement plans should create constructive pressure on all major enterprises to perform as promised. Given that the privatization prospects for KESC remain uncertain due to factors beyond the authorities' control, a financial improvement plan has been prepared, along the lines of that for WAPDA, and the authorities will give consideration to a private management contract in case privatization proves impossible. While there are delays in the privatization of the flagship telecom sector and utilities, due to the recent turbulence in world equity markets, privatization in the oil and gas sector is expected to proceed as planned.

Recent reforms in the financial sector have also been notable. The privatization of the United Bank Limited (UBL) attracted widespread domestic and foreign interest and was successfully concluded. Amendments of the central bank act have strengthened its independence in line with the Fund's Safeguards Assessment recommendations, a new Anti-money Laundering Law is expected to be promulgated shortly, and the Asian Development Bank is assisting with reforms of the Agricultural Development Bank which will include, inter alia, a cut of 50 per cent in its workforce. The authorities remain committed to implementing further reforms of the various financial instruments which, despite recent measures, still entail a considerable burden on the budget. They are looking forward to receiving soon the long-delayed FSAP mission.

In conclusion, performance under the PRGF continues to be encouraging and, in some areas, notably the external accounts, has significantly exceeded expectations. Nevertheless, the authorities recognize that much remains to be done before the benefits of the reform effort are felt by the people in terms of rising living standards and diminishing poverty. This remains the true test of the success of economic adjustment and reform. The new government, which is to assume office shortly, will inherit an economy poised for a growth upswing. The authorities are confident that the new government will build on recent successes and seize the opportunity to press ahead and deal resolutely with the remaining challenges. 